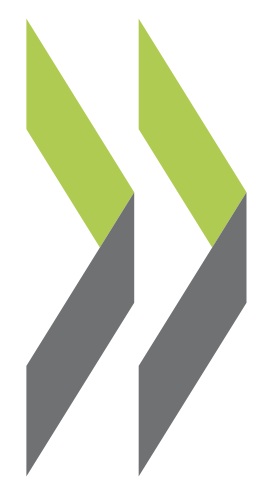

OECD Economics Department Working Papers No. 365

\author{
Corporate Taxation \\ of Foreign Direct Investment \\ Income 1991-2001
}

Kwang-Yeol Yoo 
Organisation de Coopération et de Développement Economiques

Organisation for Economic Co-operation and Development

ECONOMICS DEPARTMENT

English text only

CORPORATE TAXATION OF FOREIGN DIRECT INVESTMENT INCOME 1991-2001

ECONOMICS DEPARTMENT WORKING PAPERS NO.365

by

Kwang-Yeol Yoo

All Economics Department Working Papers are now available through OECD's Internet Web at http://www.oecd.org/eco 
Abstract/Résumé

\section{Corporate Taxation of Foreign Direct Investment Income 1991-2001}

This paper constructs indicators of tax burden on FDI in order to review their trends and cross-country patterns. Over the 1990s, the overall tax burden on inward FDI (measured by the effective marginal tax rates) fell by 8 percentage points, reflecting corporate tax reforms in some OECD countries. Nevertheless, a large variation across host countries still remains. With the effective tax rates on inward FDI differing across host countries by as much as 28 percentage points for marginal FDI and by as much as 21 percentage points for infra-marginal FDI in 2001, a cross-country comparison of tax burden indicators shows that, irrespective of the tax burden indicators chosen, Canada, Iceland and Japan are persistently ranked as high-tax host countries over the 1990s. It is also found that there is more variation in the tax burdens faced by a parent company operating in different host countries than in the tax burdens faced by subsidiaries from different home countries operating in the same host country.

JEL classification: F21, F23, G31, H25, H32, H87.

Keywords: Inward (outward) FDI, marginal (infra-marginal) investment, effective marginal (inframarginal) tax rates, withholding tax, treatment of foreign-source income, tax planning

$* * * * *$

\section{Imposition sur les sociétés du revenu de l'Investissement Direct Étranger (l’IDE)}

Cette étude construit les indicateurs de la charge fiscale sur l'IDE afin d'examiner leurs tendances et les caractéristiques par pays. Pendant les années 90, la charge fiscale globale sur les entrées d'IDE (mesurée par les taux marginaux effectifs d'imposition) a diminué de 8 points de pourcentage, reflétant des réformes de l'imposition du revenu des sociétés dans certains des pays de l'OCDE. Néanmoins, une grande diversité demeure entre pays d'accueil. Les taux marginaux effectifs d'imposition sur les entrées d'IDE différaient selon les pays d'accueil d'environ 28 points de pourcentage pour l'IDE marginal et d'environ 21 points de pourcentage pour l'IDE infra-marginal en 2001. Une comparaison internationale des indicateurs de charge fiscale montre que, quels que soient les indicateurs choisis, le Canada, l'Islande et le Japon figurent systématiquement parmi les pays d'accueil à forte fiscalité au cours des années 90 . On a également pu constater que les charges fiscales auxquelles doit faire face une société-mère variaient plus, lorsque celle-ci opérait dans différents pays d'accueil, que les charges fiscales auxquelles doivent faire face des filiales de différents pays d'origine opérant dans le même pays d'accueil.

Classification JEL: F21, F23, G31, H25, H32, H87

Mots-clés: Entrées (sorties) l'IDE, l'IDE marginal (infra-marginal), les taux marginaux (effectifs) d'imposition, retenues à la source, traitement des revenus de source étrangère, planification fiscale

Copyright OECD, 2003

Applications for permissions to reproduce or translate all, or part of, this material should be made to: Head of Publications Service, OECD, 2 rue André Pascal, 75775 Paris Cedex 16, France. 


\section{TABLE OF CONTENTS}

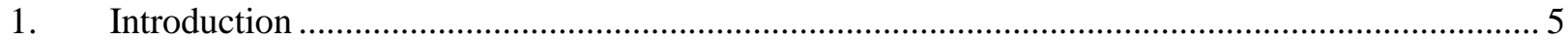

2. Description of the corporate income tax system and the effective tax rates on FDI ......................5

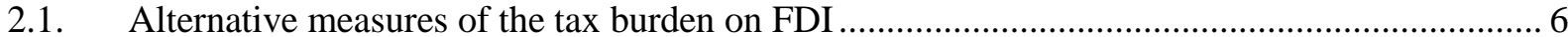

2.2. Conceptual framework for the EATR and the EMTR ….................................................... 7

3. EMTR and EATR on cross-border income of foreign affiliates ............................................ 10

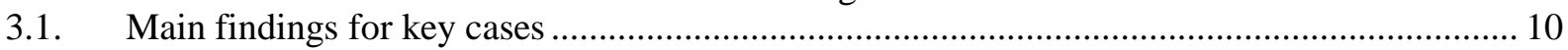

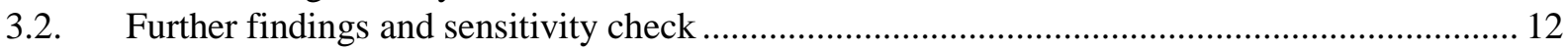

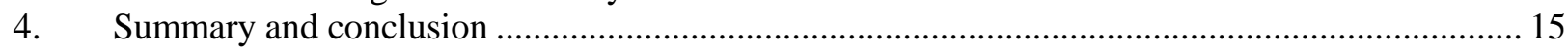

Appendix 1: The methodology of calculating the EMTR and EATR on FDI ..................................... 40

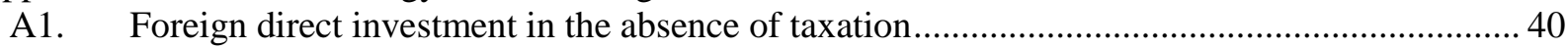

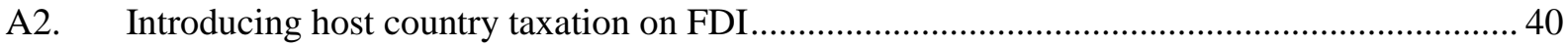

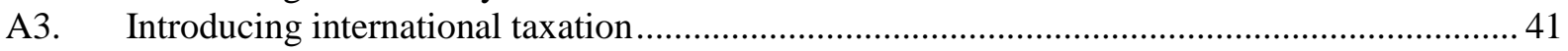

A4. Foreign direct investment in face of the home and host country taxation ................................ 42

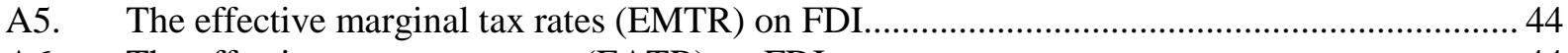

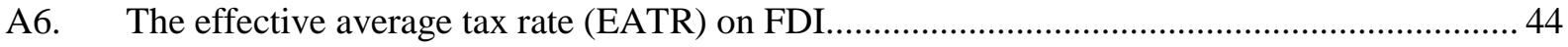

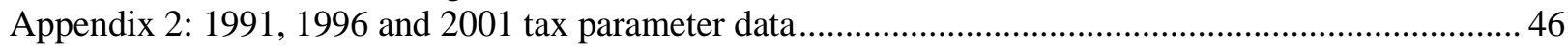

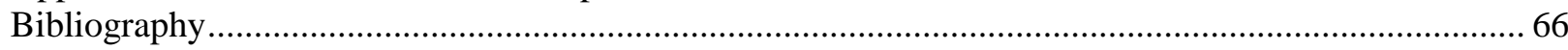

\section{Boxes}

Box 1. Assumptions underlying the calculation of the effective tax rates 8

\section{Tables}

1. Selected examples of corporate tax incentives in OECD countries; 2001 ................................... 17

2. Evolution of the overall corporate tax rates, including local taxes........................... 18

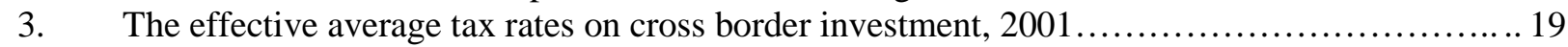

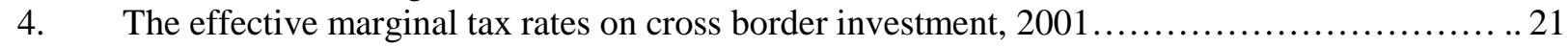

5. The effective average tax rates on manufacturing FDI when the subsidiary is financed

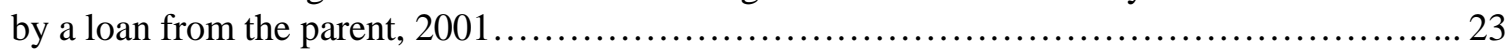

6. The effective average tax rates on manufacturing FDI when the subsidiary is financed

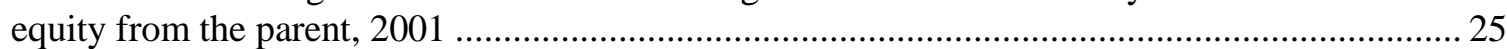

7. The effective average tax rates on manufacturing FDI when the subsidiary is financed

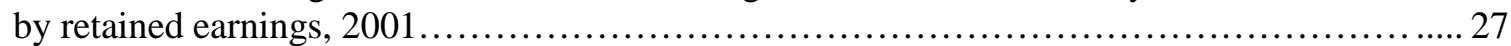

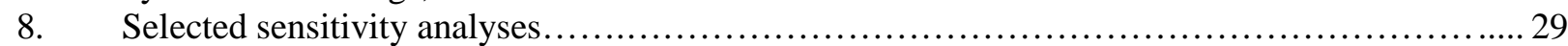

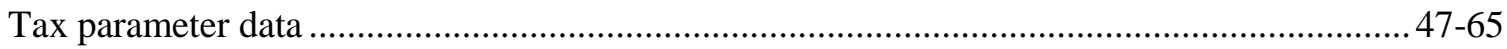




\section{Figures}

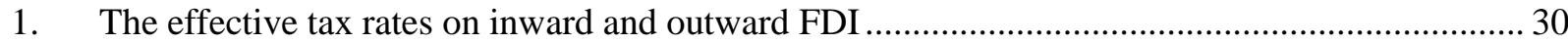

2. Variation of the effective tax rates on inward FDI applied by host country, 2001 .......................32

3. Variation of the effective tax rates on outward FDI applied by home country, 2001 ....................33

4. Change in the effective tax rates on inward FDI measured relative to the OECD average............34

5. Change in EMTR and EATR on outward FDI, measured relative to the OECD average..............35

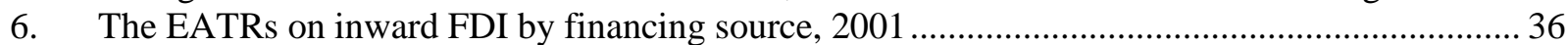

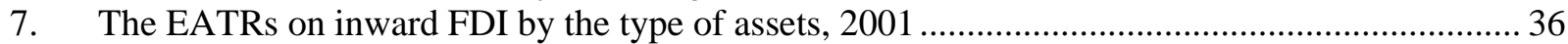

8. The EATRs on outward FDI - exemption vs. credit system countries, 2001 .............................. 37

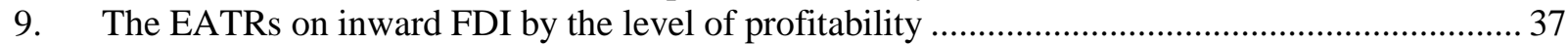

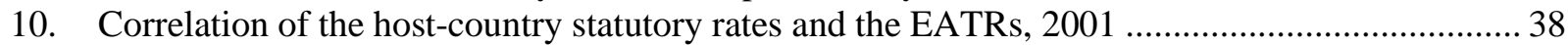

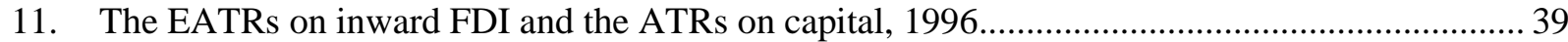


ECO/WKP(2003)19

\title{
CORPORATE TAXATION OF FOREIGN DIRECT INVESTMENT INCOME 1991-2001
}

\author{
by
}

Kwang-Yeol Yoo ${ }^{1}$

\section{Introduction}

1. Corporate taxation is one of the factors that determine the rate of return on FDI. By creating a wedge between its pre-tax and post-tax rate of return, taxation can discourage FDI flows. At the same time, the differences in tax treatment of FDI across host countries can also affect the cross-country distribution of FDI. Tax polices have converged to some extent over the past decades, but differences in corporate tax systems across OECD countries remain wide. In a world of increasing capital mobility, these differences in tax burden may influence investment decisions by attracting FDI to locations where the pre-tax cost of producing goods is higher but the production cost is lower in the presence of relatively low tax burden, possibly resulting in tax-induced distortions in the allocation of capital flows.

2. This paper documents the existing differences in overall tax burdens on the activities of foreign affiliates of multinational enterprises (MNEs) in OECD countries. The next section identifies the major determinants of the tax burden on FDI and describes the methodology used to construct tax burden indicators. This is followed by an analysis of the trends and cross-country patterns in effective tax rates. It should be noted at the outset that the proposed indicators are designed to reflect differences in tax codes, but cannot account for successful attempts by MNEs to avoid or defer tax obligations. Therefore the indicators are likely to represent an upper bound on the effective tax rates faced by MNEs. The final section summarises findings.

\section{Description of the corporate income tax system and the effective tax rates on FDI}

3. This section describes alternative measures of tax burdens on FDI, and sketches how the effective tax rates on FDI are constructed. Further details on data and methodology can be found in the appendices. The tax burden on FDI is usually determined by three distinct elements of tax policy: $i$ ) the domestic corporate tax systems of home and host countries, ii) the taxation of cross-border flows of income, iii) the interaction of tax systems of home and host countries. Since these three elements differ substantially across OECD countries, their interaction results in a matrix of bilateral effective tax rates among OECD countries.

1. Kwang-Yeol Yoo is an economist in the Structural Policy Analysis Division of the OECD Economics Department. The author would like to thank Giuseppe Nicoletti, Sveinbjörn Blöndal, Jorgen Elmoskov, Michael Feiner, Christopher Heady and colleagues in the OECD Economics Department and OECD Centre for Tax Policy and Administration for their valuable comments. This paper also benefited from comments by members of the Working Party No. 1 of the Economic Policy Committee and the Working Party No. 2 on Tax Policy Analysis and Tax Statistics of the Committee on Fiscal Affairs. Tax parameters used to calculate the tax burden indicators were carefully reviewed by the WP2 of the CFA in order to ensure their accuracy. 


\section{1. $\quad$ Alternative measures of the tax burden on FDI}

4. Studies on taxation and FDI have developed several indicators in order to identify how taxation affects the pattern of cross-border investment. The most commonly-used bilateral indicators are $i$ ) the effective marginal tax rate (EMTR), ii) the effective average tax rate (EATR), and iii) the average tax rate (ATR) based on the tax revenues actually collected from MNEs. The first two indicators are forwardlooking in the sense that they intend to assess tax burden for a prospective investment project, while the third one measures the realised tax liabilities on one existing capital stock. A similar ex post effective tax rate has been constructed by relating realised tax revenues directly to the relevant macroeconomic variables that are available from the national accounts and the OECD revenue statistics. ${ }^{2}$

5. The first two indicators exploit various system features embodied in the corporate income tax code. They take into account differences both in the tax base and the tax rate by considering depreciation allowances or tax incentives for various types of investment, the valuation method for inventories, withholding taxes on cross-border income flows, and other aspects of international tax treaties. Specifically, they measure the difference between the pre-tax rate of return on investment earned by the host-country company and the post-tax rate of return earned by origin-country MNEs, and thus serve as suitable indicators for a hypothetical investment project. The crucial difference between the EMTR and the EATR is that the former applies to a marginal investment project that earns the minimum required rate of return after tax, whereas the latter applies to an infra-marginal investment project that earns some economic rent, i.e. a project that earns after-tax pure profits. The EMTR was constructed by King and Fullerton (1984) and OECD (1991) for domestic and cross-border investment respectively, and was used in empirical analysis by earlier studies such as Slemrod (1990). The EATR was recently developed by Devereux and Griffith (1999) and extended by the European Commission (2001) for cross-country comparisons of tax burdens on FDI.

6. The micro-level ATR is very different in nature from the above two measures. It is calculated as aggregate taxes paid to the host country relative to the pre-tax earning and profits earned in the host country, both of which are available from tax return or accounting data. Thus, it measures the tax rate a firm actually pays on the income from all of its past investment stream and by construction reflects a wide range of investments of varying age, duration, asset composition and financing sources. International comparisons based on the ATR, however, are difficult due to differences in accounting definitions and the timing of tax payments. In addition, while the micro-level ATR accounts for MNEs' attempt to avoid or defer tax payments through so called "tax-planning" activities to some extent, recent evidence indicates that various tax-reducing alternatives to dividend repatriation, such as royalty payments to the parent and "triangular" or "multiple-tier" transactions between the parent and related foreign affiliates, cannot be captured in this simple ATR measure. ${ }^{3}$ Swenson (1994) and Collins and Shackelford (1995) used the ATR for their regression analyses of FDI.

7. This paper applies the forwarding-looking approach. This reflects not only the reality that the forwarding-looking indicator is the only feasible measure for all OECD countries, but also the complication associated with capturing or modelling various tax-planning strategies of MNEs. This paper presents both the EATR and EMTR. However, within the forward-looking approach, this paper treats the EATR as a better tax burden measure for FDI. This is due to the recognition that a MNE expects to earn an economic rent on its investment by exploiting some firm-specific advantage but, due to economies of scale

2. Mendoza et al. (1994), and recently Carey and Tchilinguirian (2000) used this approach in analysing the effect of taxation on saving, investment and employment. While this measure is relatively straightforward to construct, it is multilateral in nature and does not distinguish between the tax revenues collected from domestic and multinational firms.

See, for example, Grubert (1998), Grubert and Mutti (1991), and Altshuler and Grubert (2002). 
in production, it will choose to build one plant among alternative locations. Under this circumstance, the choice between alternative locations depends on the EATR since the MNE is likely to choose the location where the highest post-tax profits can be earned, while the optimal level of production on the chosen location depends on the EMTR.

\subsection{Conceptual framework for the EATR and the EMTR}

8. The EMTR and EATR depend on a number of simplifying assumptions. Specifically the effective tax rate on investment depends on the type of assets purchased (since different types of assets are subject to different depreciation allowance schemes) and on the source of finance (since the returns paid out as dividends, interest or capital gains may be taxed differently). Inflation also affects the effective tax rate since depreciation allowances are not indexed and nominal interest payments can be deducted as operating expense against the tax base. Cross-border investment may be subject to two forms of additional taxes: a host country's withholding tax and a home country's tax on foreign-source income. Withholding taxes may be levied on payments of dividends or interest from the subsidiary to the parent company. The country where the parent company is located may also levy the corporate income tax on the parent firm's receipts of dividends and interest from its foreign subsidiaries. As noted above, whether this leads to additional taxes on foreign-source income depends on whether the home country has adopted an exemption system or a credit system for foreign-source income, and, in the latter case, it depends on whether the tax paid abroad is bigger or smaller than the total tax liability of the parent firm.

9. This paper assumes that three types of financing are available to both a parent company and a foreign subsidiary. Thus, seven types of financing are jointly possible for FDI -- $i$ ) a subsidiary uses retained earnings; ii)-iv) a subsidiary raises new equity from the parent and the parent finances the subsidiary's equity issuance from retained earnings, new equity or debt; $v$ )-vii) a subsidiary raises debt from the parent and the parent finances this from retained earnings, new equity or debt. Devereux and Griffith (1999) showed that the economic rent on a FDI project, denoted as $R$, is divided into three parts: $i$ ) the rent attributable to FDI financed by retained earnings $\left(R_{n}^{R E}\right)$, ii) the additional cost of a parent raising external finance $\left(F_{j}\right)$, and iii) the additional cost of a subsidiary raising finance from a parent $\left(F_{n}\right)$. Thus the rent accruing to FDI is given by $R_{n}=R_{n}^{R E}+F_{j}+F_{n}$ where the values of $R_{n}^{R E}, F_{j}$ and $F_{n}$ differ across the source of finance and are affected by withholding tax rates on cross-border payments of dividends and interests and by whether home countries adopt the exemption system or credit system. The EATR is measured as the difference between the pre-tax economic rent $\left(R^{*}\right)$ and the post-tax economic rent $(R)$ per unit of investment for a given pre-tax rate of return ( $p)$, divided by the net present value of pretax income stream. That is:

$$
\text { EATR }=\frac{R_{n}{ }^{*}-R_{n}}{\left(\frac{p}{1+r}\right)} \text {, where } r \text { denotes a real interest rate }
$$

The derivation of the EMTR, on the other hand, requires the value of $p$-- this is often called cost of capital -- that produces zero post-tax economic profit $(R)$. The EMTR is the difference between the cost of capital and the post-tax rate of return as a proportion of the cost of capital.

10. In this paper, FDI is assumed to consist of three types of assets (machinery, plant and building, and inventories), with the economic depreciation and the present value of depreciation allowances differing across the types of assets. Given that intangible assets such as patents are increasingly important forms of 
cross-border investment, omitting such assets may bias tax burden indicators. ${ }^{4}$ Further assumptions are that investors are exempt from personal income taxes, and that inflation and rates of return on alternative investment for shareholders are uniform across countries, in order to single out the effect of different tax regimes on FDI. ${ }^{5}$ The technical assumptions associated with the calculation of the EATR for a cross-border investment project are described in detail in Box 1, and further details on the EMTR and the EATR formula are set out in Appendix 1. Data or information necessary to construct the EATR or the EMTR are drawn from the OECD tax database, the European Tax Handbook (various years) and other tax databases such as Price Waterhouse (1997), KPMG Taxfacts (1998) and Ernst and Young (2002), and they are summarised in Appendix 2.

\section{Box 1. Assumptions underlying the calculation of the effective tax rates}

The approach taken in this paper is to consider a parent manufacturing company that undertakes investment in the host country through a wholly-owned subsidiary. ${ }^{1}$ Further assumptions are made in order to characterise a hypothetical investment project and define economic conditions under which it is materialised.

- A real rate of after-tax return of 5 per cent on marginal investment (for the calculation of effective marginal tax rates) and a pre-tax rate of return of 20 per cent on infra-marginal investment are assumed (for the calculation of the effective average tax rates), respectively. These assumptions are in line with OECD (1991) and the European Commission (2001). The exchange rate is assumed to be constant.

- A uniform inflation rate of 2.5 per cent (the OECD average inflation rate in 2001) is assumed to hold across OECD countries.

- The effective tax rates across seven types of joint financing between a parent and a subsidiary firm are averaged using the same weights as in OECD (1991). The sources of finance for a parent company are assumed to be 55 per cent from retained earnings, 10 per cent from new equity, and 35 per cent from debt. Financing sources for a subsidiary are assumed to be 33 per cent from retained earning, 33 per cent from new equity from parent, and 33 per cent from debt from the parent.

- The effective tax rates across three types of assets are averaged using the following weights: 28 per cent for building, 50 per cent for plant and machinery, and 22 per cent for inventories, as in OECD (1991).

4. European Commission (2001) assumed five types of assets, including financial assets and intangible assets. This requires information on depreciation allowance scheme for intangible assets. At present, the information is not available for all Member countries from the OECD tax database or other sources in a reliable manner and thus the same assumption as in OECD (1991) was maintained in this paper. Nevertheless, the sensitivity analysis in European Commission (2001) broadly confirms that there is no significant difference in qualitative results by assuming three or five types of assets. However, to the extent that royalty payments often work as an alternative to repatriation of taxable dividends, omitting intangible assets implies that tax-planning of MNEs cannot be adequately modelled. See Grubert (2001) for the way in which US MNEs can shield foreign-source royalty income from U.S. tax. An issue of rents accruing from intangible assets was partly addressed by considering the EATRs on infra-marginal investment.

5. In addition to the complexity that personal income taxation in the home country brings into the calculation of the bilateral effective tax rates, the fact that shareholders may face different effective tax rates and may often be non-resident makes the consideration of personal income rather irrelevant for FDI decisions. Moreover, this study is designed to identify the impact of differences in corporate tax systems on multinationals' behaviour with an eye to illustrating relevant policy options. It is also often the case that a large group of shareholders such as pension funds are tax exempt on dividend income or capital gains. 
- The economic depreciation rates are assumed to be 12.25 per cent for plant and machinery, 3.61 per cent for building and 0 per cent for inventories, as in OECD (1991).

- All investments undertaken are assumed to be profitable, thus the possibility of carrying loss or unspent credits forward is ignored.

The features of the domestic tax system taken into account in this paper are the statutory tax rate and the taxable base. The statutory corporate tax rate represents overall or combined tax rates, including local profit taxes and surcharges, but excludes the property tax. In calculating the taxable base, depreciation allowances and additional tax allowances or credits — as long as they are general and significant — are taken into account. Many OECD countries also have tax incentives specific to certain underdeveloped regions or specific to certain spending items such as R\&D or spending by SMEs. In general, these incentives are not incorporated in the calculation. When the corporate tax codes offer more than one option in calculating capital allowances or do not provide the details on capital allowances, certain assumptions are introduced to facilitate the calculation and international comparison. ${ }^{2}$ Some countries operate special corporate reserve schemes in which contributions to the reserves are deductible from taxable income. Because of their complexity, these reserve provisions are not taken into account. ${ }^{3}$ Also, tax-planning activities of a multinational company in order to exploit the differences in tax systems across countries are not taken into account. These assumptions are broadly in line with OECD (1991) and European Commission (2001). This paper constructed both the EMTR and the EATR for 1996 and 2001. The estimated bilateral EMTRs and EATRs as of 2001 are shown in Tables 3 through 7. The simple average values of host-country or home-country effective tax rates are presented in the last column or the last row of the tables, and are used in this paper for analysing cross-country patterns. But employing other weighting schemes may change the result. ${ }^{4}$ The values of the tax parameters applied for the calculation of the effective tax rates on FDI are provided in Appendix 2.

1. Sensitivity analysis has shown that changes in assumptions to account for some characteristics of non-manufacturing firms do not affect the results substantially. See the next section.

2. For example, when the choice between declining-balance (DB) and straight-line (SL) is optional (or the switch between these two methods is optional during the asset life), the DB scheme and the corresponding rate are chosen. When the DB scheme is complex or no DB rate is known, however, the SL scheme and its rate are used. When multiple rates are shown for various types of assets, a typical or representative rate is chosen. In the absence of relevant information in the available tax codes, seven years of useful life for machinery along with the assumption of "until fully depreciated" is taken. When the optional choice between LIFO (last-in, first-out), average cost method or FIFO (first-in, first-out) is allowed for the purpose of inventory valuation, the tax minimising possibility i.e. the LIFO (or average cost method) is chosen against the average cost method (or FIFO).

3. For example, Sweden allows the establishment of a profit periodisation reserve and a replacement reserve from which contributions are tax-deductible. In practice, this can significantly reduce the effective tax rates.

4. Using FDI weights creates the problem of endogeneity between FDI and effective tax rates, so this weighting scheme is not used in this paper. Using FDI weights, however, does not seem to change the country ranking significantly.

11. While the estimated tax indicators succinctly summarise the major features of the tax system, a few shortcomings associated with the estimation of tax indicators are noteworthy. First, tax indicators do not take into account the possibility of a multinational to reallocate taxable income across different countries with a view to minimising its tax burden. International investors indeed have access to alternative methods of financing FDI, arranging transactions between related parties located in different countries and changing the timing of repatriation of income to a parent company. ${ }^{6}$ To the extent that tax-planning by

6. Numerous studies have pointed out that the financial incentives of the MNEs to shift profits from one host country to the other are large. For example, Weichenrieder (1996) and Grubert (1998) confirmed a frequent reliance on intra-company loans for financing foreign affiliates in high corporate tax countries in order to exploit a favourable tax treatment for debt-financing. The phenomenon that firms manipulate prices used in intra-firm transactions with a view to reducing total tax liabilities has been confirmed by Grubert and Mutti (1991), Hines and Rice (1994), Harris (1993), Rousslang (1997) and Clausing (1998). Hines and Hubbard (1990) showed that multinationals also adjust the timing of their dividend repatriations from foreign subsidiaries. Recently Desai, Foley and Hines (2002), after reviewing affiliate-level data on the behaviour 
MNEs reduces the tax wedges across host countries, the estimated tax indicators will overestimate the cross-country difference in the tax burdens on FDI. Second, tax indicators do not reflect a full range of special investment incentives. Many OECD countries have a number of tax incentives specific to certain underdeveloped regions or specific to certain spending categories such as R\&D or spending by SMEs. However, in some countries, the conditions that entitle investors to take advantage of these incentives are often general and the estimated EATR may overestimate the tax burden in those countries (Table 1). ${ }^{7}$ Thus the estimated tax indicators should be interpreted with caution especially when the difference in the effective tax rates between countries is relatively small. Finally, the tax burden indicators are based on economic assumptions that are tailored to manufacturing, though a large and increasing share of FDI actually concerns non-manufacturing industries. Sensitivity analysis, however, suggests that adapting the indicators to meet non-manufacturing characteristics may not change the results substantially (see below). As noted earlier, the calculations below do not cover income from intangible assets.

\section{[Table 1. Selected examples of corporate tax incentives in OECD countries; 2001]}

\section{EMTR and EATR on cross-border income of foreign affiliates}

\subsection{Main findings for key cases}

12. Over the past decade, the overall tax burden on cross-border activities of foreign affiliates has declined. When measured by the EMTR on inward FDI (i.e. the EMTR faced in each host country by a foreign investor from the average OECD country), the tax burden on average fell by 8 percentage points over the 1990s (Figure 1, panel A). The EATR followed a similar pattern over the second half of the 1990s, i.e. the period for which data are available to calculate such rates (Figure 1, panel B). The decline in tax burden on activities of foreign affiliates is partly due to corporate tax reforms in European countries, including those of Germany and Italy in recent years, and rate cuts by Nordic countries in the early 1990s, although tax-base broadening has partially offset the effect of the statutory rate cut on the overall tax burden (Table 2). Eastern European countries also cut the statutory corporate income tax rate substantially over the same period.

\section{[Figure 1. The effective tax rates on inward and outward FDI]}

\section{[Table 2. Evolution of the overall statutory corporate tax rates, including local taxes]}

13. Despite a trend decline in the tax burden on FDI, a large variation in the tax burden faced by the average investor across host countries still remains (Figure 1, panels A and B). For example, the effective tax rates on inward FDI differed across host countries by as much as 28 percentage points for marginal

of US companies, suggested that the previous US evidence on the impact of taxation may underestimate the effect of taxation on the behaviour of multinationals. This was based on their empirical finding that the investment pattern of indirectly-owned affiliates of US multinationals was considerably more sensitive to local tax rates than was the investment pattern of directly-owned foreign affiliates. At the same time, efforts have been made to curb aggressive tax planning activities of MNEs - such as the practice of allocating taxable profits to low-tax countries by manipulating prices in intra-firm transactions (transferpricing) and the practice of allocating company debt and the associated reduction for interest payments to subsidiaries in high-tax countries (thin capitalisation). In addition, many countries also responded to these issues by formulating very complex tax codes. Those include deferral of taxes on foreign-source income, apportionment rules of a parent's expenses, and special rules on foreign sales corporations. See Gresik (2001) for details.

7. For example, Greece, Turkey, Hungary, Czech Republic, Poland and Korea maintain tax holidays and/or sizeable tax credits for investment (or FDI) only, although those incentives are often confined to certain regions or industries (Table 1). 
FDI and by as much as 21 percentage points for infra-marginal FDI in 2001 (Tables 3 and 4). However, the dispersion of tax burdens on inward FDI across host countries has narrowed somewhat for marginal FDI, and to a larger extent for infra-marginal FDI (Figure 1, panel A and B). This limited convergence of tax burdens resulted mainly from progress made in co-operating bilaterally or multilaterally, in the context of the OECD and the EU, in order to harmonise tax policies on cross-border activities, with an eye to limiting the over-taxation of cross-border FDI income flows. ${ }^{8}$ Nevertheless, it is also noteworthy that, in a given host country, the effective tax rates faced by foreign subsidiaries also vary widely, depending on the origin of the investor country, due to the cross-country differences in withholding tax rates on cross-border flows of dividends and interest income vis-à-vis partner countries, and the interaction of home and host countries' tax systems. The difference between the maximum EATR and the minimum EATR in a given host country ranged from 9 to 31 percentage points in OECD countries in 2001 (Figure 2, panel B, and Table 3). Similar differences between the maximum and the minimum rates were observed for the EMTR on inward FDI for a given host country (Figure 2, panel A, and Table 4).

\section{[Table 3. The effective average tax rates on cross border investment, 2001]}

\section{[Table 4. The effective marginal tax rates on cross border investment, 2001]}

\section{[Figure 2. Variation of the effective tax rates on inward FDI applied by host country, 2001]}

14. Similarly, depending on the country where a parent company is resident, the effective tax rates on outward FDI (i.e. the tax burden faced in the average OECD host country by a foreign investor from each OECD country) varied on average by 12 percentage point for both marginal FDI and infra-marginal FDI in 2001 (Figure 1, panels C and D). However, this average figure conceals substantial variation of the effective tax rates on outward FDI originated from the same home country. Indeed, the comparison of bilateral effective tax rates on inward and outward FDI indicates that there is more variation in the tax burdens faced by a parent company operating in different host countries than in the tax burdens faced by subsidiaries from different home countries operating in the same host country (Figures 2 and 3). This suggests that host-country taxation is much more important to international investors than home-country taxation, ${ }^{9}$ and the wide variation in a host country's tax treatment of FDI is responsible for this phenomenon.

[Figure 3. Variation of the effective tax rates on outward FDI applied by home country, 2001]

15. A closer look at tax burden indicators on foreign affiliates further reveals how corporate tax policies differ among OECD Member countries. Irrespective of the tax indicator chosen, Canada, Iceland and Japan are persistently ranked as high-tax host countries over the 1990s (Figure 4). On the other hand, tax reforms in Italy (1998) and Germany (2001) reduced their effective tax rates on inward FDI towards

8. For example, the OECD Model Tax Convention and the Guidelines on Transfer Pricing helped OECD Member countries to extend the network of bilateral double taxation treaties and harmonise certain aspects of taxation on multinational activity. On the other hand, the European Union took several steps in order to remove tax obstacles within its internal market. Those measures include notably the Parent-Subsidiary Directive (for the elimination of double taxation on cross-border dividend payments between parent and subsidiary companies located in EU regions) and the Arbitration Convention (for the provision of a dispute resolution procedure in the area of transfer pricing). In addition, some countries like New Zealand and Australia in the early to mid-1990s unilaterally exempted cross-border flows of dividends and/or interest income from tax under certain conditions in order to offset the negative effect of high withholding taxes on FDI inflows.

9. In other words, the current tax regime in OECD countries is a mixture of (income) source-based and (parent) residence-based taxation, with more weight on income source-based taxation. 
the OECD average level over the same period, and New Zealand introduced measures to offset high withholding treaty tax rates on cross-border income in mid-1990s. ${ }^{10}$ As of 2001, the EATR on inward FDI was relatively high in Japan and Turkey (at above 40 per cent), followed by Canada, Iceland and the United States. In Australia, Denmark, Finland, Hungary, Ireland, Sweden, Switzerland and the United Kingdom, the EATR on inward FDI was relatively low at below 30 per cent (Figure 4, panel B, and Table 3). ${ }^{11}$ It appears that relatively high EATRs are associated with high withholding taxes (Iceland, and to a lesser extent Canada and Turkey) or high statutory corporate tax rates (Japan and Turkey). The EATR on outward FDI, on the other hand, was relatively high in Turkey, Japan, New Zealand (at above 36 per cent), while in Denmark, Finland, Sweden and the Netherlands it was relative low (Figure 5 panel B, and Table 3). The adoption of the credit system in high-tax countries (Japan and Turkey) and/or the limited network of bilateral tax arrangements vis-à-vis OECD member countries (New Zealand, and to a lesser extent Turkey) seem responsible for relatively high EATRs on outward FDI.

\section{[Figure 4. Change in the effective tax rates on inbound FDI measured relative to OECD average]}

\section{[Figure 5. Change in EMTR and EATR on outbound FDI measured relative to the OECD average]}

\section{2. $\quad$ Further findings and sensitivity check}

16. Other findings drawn from the comparison of bilateral tax burden indicators (mainly the EATRs) are summarised below.

- EATR on FDI by type of subsidiary's finance. In terms of corporate financing, 22 out of 30 OECD countries' tax systems favour inward FDI financed by debt from the parent (which secures financial resources by a combination of a loan, equity issuance and its retained earnings) over FDI financed by equity from the parent (which secures financial resources by a combination of a loan, equity issuance and its retained earnings) or a subsidiary's retained earning (Figure 6 and Tables 5-7). In the remaining countries (except Ireland and Hungary), the difference between the effective tax rate on FDI financed by a parent's loan and the effective tax rate on FDI financed by an alternative tax-efficient mode is minor. The tax advantage of debt-finance from a parent originates from the deductibility of interest payments from the taxable base, especially in the cases in which a host country

10. Since 1998, business income in Italy is subject to a dual rate. A reduced rate of 19 per cent (23.25 per cent including 4.25 per cent of regional tax) applies on the portion of income derived from the increase in the equity capital of the company, as compared with the equity capital existing at the end of 1996. The German tax reform (effective as of the beginning of 2001) cut the headline corporate tax rate to 25 per cent. It was in part financed by the broadening of the tax base, including the abolition of the split rate system on distributed profits and retained earnings, and the replacement of the full imputation system by a shareholder relief system with respect to corporate profit taxation. In the context of cross-border taxation, New Zealand introduced the foreign investor tax credit (FITC, 1996) and approved issue levy (AIL, 1992) regime for the favourable treatment of dividends and interest income associated with FDI, respectively. In order to reflect the FITC regime in New Zealand, this paper models the effect of the FITC as a 33 per cent corporate tax rate and zero withholding tax on dividends.

11. The difference in country rankings between the EMTR-based indicator and the EATR-based indicator could be interpreted as the different tax treatment for marginal FDI and infra-marginal FDI. For example, Turkey is ranked as a low-tax country for marginal FDI but as a high-tax country for infra-marginal FDI. This is primarily due to the combination of large capital allowances (at least 40 per cent extra allowances are provided in addition to ordinary capital allowances) and a high statutory tax rate. For marginal FDI that has a smaller size of taxable profits, the importance of capital allowances is relatively high. On the other hand, for infra-marginal FDI, the statutory tax rate becomes much more important since the value of the capital allowances to investors diminishes with a rise in taxable profits. 
has a higher corporate tax rate than a home country (and this partly explains why debt finance is not favoured in Hungary and Ireland where the corporate tax rate is fairly low). However, tax savings from interest deductibility could be offset by the withholding tax on cross-border payments of interests. This offsetting force is stronger if the home country has a credit system and its tax rate is relatively high. This appears to explain why debt finance does not always have an absolute advantage over other financing modes in cross-border investment. This paper did not find any evidence that equity finance is taxed at a rate higher than finance by retained earnings, though equity finance is in general subject to the withholding tax on dividends paid by a subsidiary to a parent. ${ }^{12}$

[Figure 6. The EATRs on inward FDI by financing source, 2001]

[Table 5. The effective average tax rates on manufacturing FDI when the subsidiary is financed by a loan from the parent, 2001]

[Table 6. The effective average tax rates on manufacturing FDI when the subsidiary is financed by new equity from the parent, 2001]

[Table 7. The effective average tax rates on manufacturing FDI when the subsidiary is financed by retained earnings, 2001]

- EATR on FDI by assets. Bilateral EATRs suggest that FDI in machinery is taxed lightly compared with FDI in buildings or inventory (Figure 7). This is because the domestic corporate tax codes generally encourage machinery investment by providing a relatively large depreciation allowance or tax credit. However, unlike the case of financing, crossborder taxation does not further distort the choice between the types of assets purchased.

[Figure 7. The EATRs by the type of assets, 2001]

- EATR on FDI by exemption vs. credit system. Differences in the treatment of foreignsource income have implications for the patterns of the EATRs on outward FDI. A multinational from a credit-system country in general faces a higher effective tax rate on its outward investment than its counterparts from exemption-system countries (Figure 8), unless a multinational firm is able to fully offset the effects of home country taxation through tax-planning. This is because a MNE from an exemption-system country does not have to pay tax on its foreign-source income at home in addition to taxes paid to a host country, while MNEs from credit-system countries are only able to credit foreign tax payments against their overall tax liabilities to a home country. ${ }^{13}$ On the other hand, the dispersion of the effective tax rates on outward FDI (measured by its standard deviation) is on average larger in exemption countries (Figure 8 ). ${ }^{14}$ This can be explained by a built-in buffer operating under the credit system that effectively reduces the variation of after-tax

12. This is probably due to the fact that a relatively large number of countries, including the EU member states, exempt foreign-source dividend income and the fact that some countries, like Austria and Italy, provide tax advantage to equity finance (see Table 1).

13. However, Altshuler and Grubert (2002) indicated that the availability of various strategies other than dividend repatriation enables US multinationals to avoid additional US tax which is applicable under the current credit system.

14. An observed large variation of the EATRs on outward FDI in some credit-system countries can be attributed to large variation of the withholding tax rates vis-à-vis partner countries. 
income repatriated by a foreign subsidiary through additional home country tax on crossborder income.

\section{[Figure 8. The EATRs on outward FDI — exemption vs. credit system countries, 2001]}

17. As noted earlier, the tax burden indicators depend upon a number of simplifying assumptions. Sensitivity analysis based on the changes in some of the main parameters fed into the EMTR and EATR formulae suggest that, in general, outcomes are not qualitatively affected by changes in economic assumptions.

- At low levels of the pre-tax rate of return or profitability, the EMTRs and EATRs are closely related. However, the EATR tends to have a closer relation to the statutory tax rate in the host country when the level of pre-tax rate of return rises (Figure 9). At high levels of pre-tax profitability, the EATR is often even higher than the statutory rate, due to the existence of withholding taxes on cross-border payments of income and different treatment of foreign-source income across home countries. A higher EATR with a rise in the pre-tax rate of return indicates that the value of various tax incentives to foreign investors diminishes, as the size of profits relative to the investment cost grows larger. For more profitable projects, the difference in effective tax rates across different types of finance, assets and countries becomes much narrower. Nevertheless, the qualitative conclusions drawn earlier still hold, as varying the level of profitability does not alter the relative position of the countries significantly. In any event, the statutory corporate tax rate turns out to be highly correlated with the EATRs, implying that the statutory rate is one of major factors in determining the tax burden on FDI in a large number of OECD countries (Figure 10).

\section{[Figure 9. The EATRs on inward FDI by the level of profitability]}

\section{[Figure 10. Correlation of the host-country statutory rates and the EATRs, 2001]}

- Estimates of the EMTRs and the EATRs on FDI, using alternative weights on asset composition, are very highly correlated with the benchmark indicators (Table 8 ). ${ }^{15}$ The correlations between the new and benchmark bilateral indicators are in the range of 0.87-1.0, with a majority of measured correlations being 0.98 . The experiment on alternative asset weights is intended to capture the tax burden on non-manufacturing FDI in light of the fact that a large part of available data on FDI covers non-manufacturing sectors. Due to a lower weight on machinery that often benefits from favourable tax treatment, the new measures of the EMTRs and EATRs on FDI tend to be higher than benchmark measures.

- Assuming higher inflation raises both the EMTRs and the EATRs (Table 8). In general, higher inflation (thus higher nominal interest) reduces the tax burden on debt-financed FDI through a rise in deductible operating expenses. However, this effect is more than offset by a fall in the net present value of depreciation allowances since they are usually not indexed. ${ }^{16}$ In addition, higher inflation affects the effective tax rates differently depending

15. It is assumed that FDI consists of 40 per cent machinery, 40 per cent buildings and 20 per cent inventories. In addition, for Canada and Ireland, the standard corporate tax rates of 42.1 and 20 per cent are applied respectively instead of the 34.1 and 10 per cent rates on manufacturing that were used to estimate the benchmark indicators.

16. For Iceland and Mexico, the depreciation base is indexed to inflation. 
on the method used to evaluate inventories. For example, FDI in host countries that have a FIFO (first-in, first-out) system are subject to a higher inflation tax on their inventories than FDI in host countries that adopt the LIFO (last-in, last-out) or average cost method.

- With a rise in the real interest rate, the EATRs tend to decline (Table 8). The fall in the EATR is mainly due to the assumption of 20 per cent pre-tax rate of return, and this means that taxable income from FDI is smaller in the face of a higher interest rate and thus is subject to a lower tax burden as shown in Figure 9. On the other hand, the EMTR, which will have zero after-tax return anyway, does not change much with a rise in the real interest rate.

\section{[Table 8. Selected sensitivity analyses]}

18. As noted earlier in this paper, there are a number of tax burden measures on investment. As shown in Carey and Tchilinguirian (2000), the estimated macro-level average tax rates (ATRs) on capital differ substantially, depending on which measure is used as capital income, i.e. net operating surplus or gross operating surplus (Figure 11) ${ }^{17}$ On the basis of gross operating surplus measures of the ATRs, the comparison of the EATR on FDI and the ATR on capital suggests that FDI is in general taxed at a higher rate than domestic investment (Figure 11, panel B). ${ }^{18}$ The presence of withholding taxes that often lead to over-taxation of FDI partly explains this phenomenon. Moreover, in countries where taxes paid by resident foreign affiliates account for a large share of total tax receipts, a lower level of ATR on capital relative to the EATR suggests that tax-planning by multinationals takes place in order to minimise the overall tax burden.

\section{[Figure 11. The EATRs on inward FDI and the ATRs on capital, 1996]}

\section{Summary and conclusion}

19. This paper developed two sets of forward-looking bilateral tax burden indicators: the effective marginal tax rates (EMTR) and the effective average tax rates (EATR). Both measures exploit the system features of corporate tax codes in OECD countries and allow for the interaction of home and host country taxation. However, the former is relevant for a marginal investment project that yields the minimum posttax rate of return, while the latter is relevant for an infra-marginal investment project that yields post-tax pure profits. These indicators were used to identify trends and cross-country patterns in bilateral and multilateral FDI taxation. The main conclusions are summarised below:

- The overall tax burden on cross-border activities of MNEs, measured by the EMTR on inward FDI (i.e. the EMTR faced in each host country by a foreign investor from the

17. In principle, the ATR based on net operating surplus measures the underlying tax burden more accurately since it excludes the charges for depreciation of fixed assets. In reality, however, the way individual countries measure depreciation charges in the National Accounts vary a lot mainly due to the differences in service lives. For example, the OECD average of the ATRs was 13 percentage points higher and the variation in ATRs across countries were two times higher over 1991-1997 when net operating surplus was used to proxy capital income. Therefore Carey and Tchilinguirian (2000) used ATRs based on gross operating surplus for cross-country comparisons, though these measures tend to overestimate capital income.

18. Direct comparison between the two measures is problematic, since Carey and Tchilinguirian's (2000) ex post measure of ATR on capital included taxes paid by foreign affiliates resident in domestic (host) country and reflected tax-planning activities in order to minimise the tax burden by resident firms. In addition, the ATR on capital covers taxes on capital held by households and unincorporated enterprises. 
average OECD country), fell on average by 8 percentage points over the 1990s. Corporate tax reforms in some OECD countries contributed to a trend decline of the overall tax burden.

- The variation in the tax burden faced by the average investor across host countries remains wide. However, limited convergence of tax burdens across host countries has been achieved via bilateral and multilateral cooperation aimed at harmonising tax policies on cross-border activities.

- There is more variation in the tax burdens faced by a parent company operating in different host countries than in the tax burdens faced by subsidiaries from different home countries operating in the same host country. This confirms a common perception that host-country taxation is much more important to multinationals than home-country tax treatment of foreign-source income.

- Tax burdens on inward FDI were relatively high at above 40 per cent in Japan and Turkey. They were followed by Canada, Iceland and the United States. Relatively higher EATRs appear to be associated with high withholding taxes (Iceland, to a lesser extent Canada and Turkey) or high statutory corporate tax rates (Japan and Turkey).

- A MNE from a credit-system country in general faces a higher effective tax rate on its outward investment than its counterparts from exemption-system countries, unless it is able to fully offset the effects of home-country taxation through tax-planning. On the other hand, the dispersion of the effective tax rates on outward FDI is on average larger in exemption countries because a built-in buffer operating under the credit system reduces the variation of after-tax income repatriated by a foreign subsidiary through additional homecountry tax on cross-border income.

- The EATR tends to have a closer relation to the statutory tax rate in the host country when the level of pre-tax rate of return rises. At low levels of the pre-tax rate of return, the EMTRs and EATRs are closely related. However, at high levels of pre-tax rate of return, the EATR is often even higher than the statutory rate, due to the existence of withholding taxes on cross-border payments of income and different treatment of foreign-source income across home countries. 


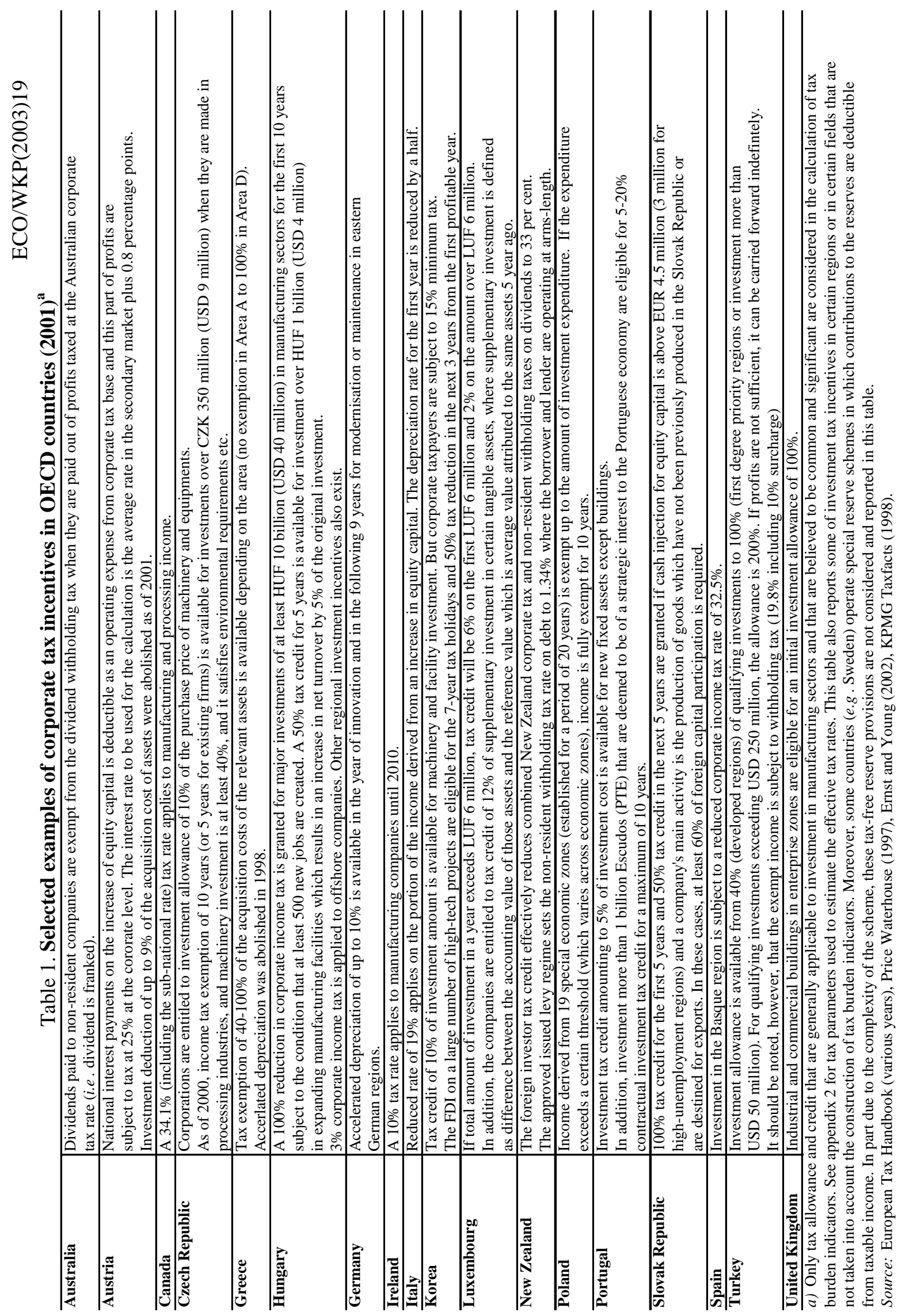


Table 2. Evolution of the overall statutory corporate tax rates, including local taxes ${ }^{\mathbf{a}}$ per cent

\begin{tabular}{|c|c|c|c|}
\hline & 1991 & 1996 & 2001 \\
\hline Australia & 39 & 36 & 30 \\
\hline Austria & 39 & 34 & $34^{\mathrm{d}}$ \\
\hline Belgium & 39 & 40.2 & 40.2 \\
\hline Canada & $35.7^{\mathrm{c}}$ & $35.6^{\mathrm{c}}$ & $34.1^{\mathrm{c}}$ \\
\hline Czech Republic & - & 39 & 31 \\
\hline Denmark & 38 & 34 & 30 \\
\hline Finland & 40.2 & 28 & 29 \\
\hline France & $34 / 42^{b}$ & 36.7 & 35.3 \\
\hline Germany & $56.5 / 44.3^{\mathrm{b}}$ & $57.4 / 42^{b}$ & 38.9 \\
\hline Greece & 46 & 40 & 37.5 \\
\hline Hungary & - & 18 & 18 \\
\hline Iceland & 45 & 33 & 30 \\
\hline Ireland & $10^{\mathrm{c}}$ & $10^{\mathrm{c}}$ & $10^{\mathrm{c}}$ \\
\hline Italy & 47.8 & 52.2 & $40.3^{\mathrm{e}}$ \\
\hline Japan & 50 & 49.9 & 41.4 \\
\hline Korea & 37.4 & 31.1 & 30.8 \\
\hline Luxembourg & 39.3 & 39.1 & 37.5 \\
\hline Mexico & - & 34 & 35 \\
\hline Netherlands & 35 & 35 & 35 \\
\hline New Zealand & 33 & 33 & 33 \\
\hline Norway & 50.8 & 28 & 28 \\
\hline Poland & - & 40 & 28 \\
\hline Portugal & 39.6 & 39.6 & 35.2 \\
\hline Spain & 35.3 & 35 & 35 \\
\hline Sweden & 30 & 28 & 28 \\
\hline Switzerland & 38.4 & 39.8 & 25.3 \\
\hline Turkey & 49.2 & 43 & 44.5 \\
\hline United Kingdom & 34 & 33 & 30 \\
\hline United States & 38.3 & 39.5 & 39.5 \\
\hline
\end{tabular}

a) Overall corporate income tax rates include local profit taxes and surcharges. When local profit tax differs across jurisdictions, a typical local rate is chosen. Surcharges are also included here. Where a progressive rate structure applies (e.g. Switzerland), the top marginal rate is shown.

b) Rate on retained earning/distributed profits. A split rate system was abolished in France (1992) and Germany (2001).

c) For manufacturing industries only.

d) $25 \%$ rate is applied for the profits amounting to a notional interest on additions to own capital since 2000 .

e) As of 1998, business income is subject to a dual rate (so called "dual income tax regime"). A reduced rate of $19 \%$

(23.25\% including $4.25 \%$ of regional tax) applies on the portion of income derived from the increase in equity capital.

Source: OECD Tax Database, European Tax Handbook (various years), Price Waterhouse (1997);

Ernst and Young (2002), KPMG Taxfacts (1998), OECD (1991). 


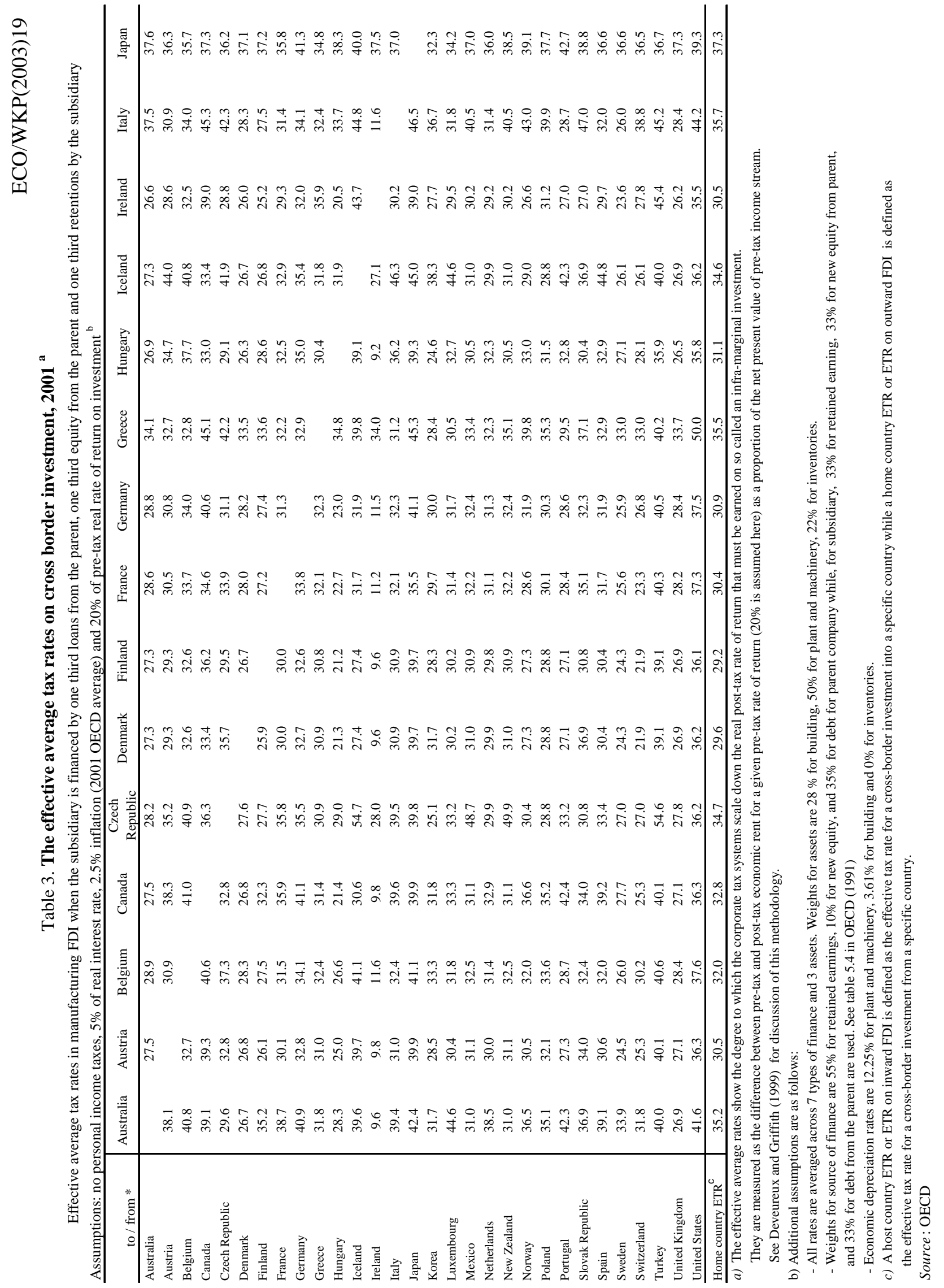




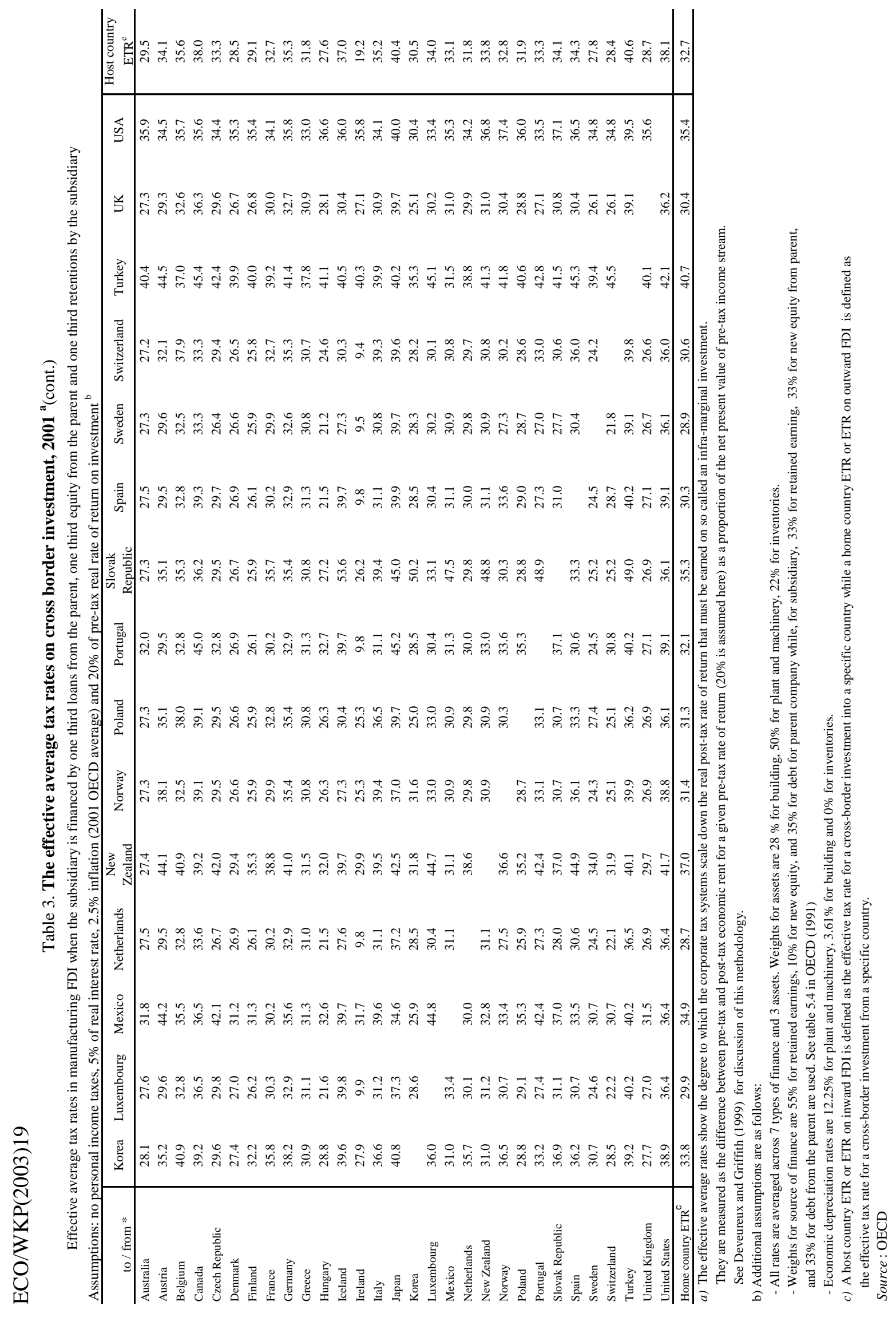




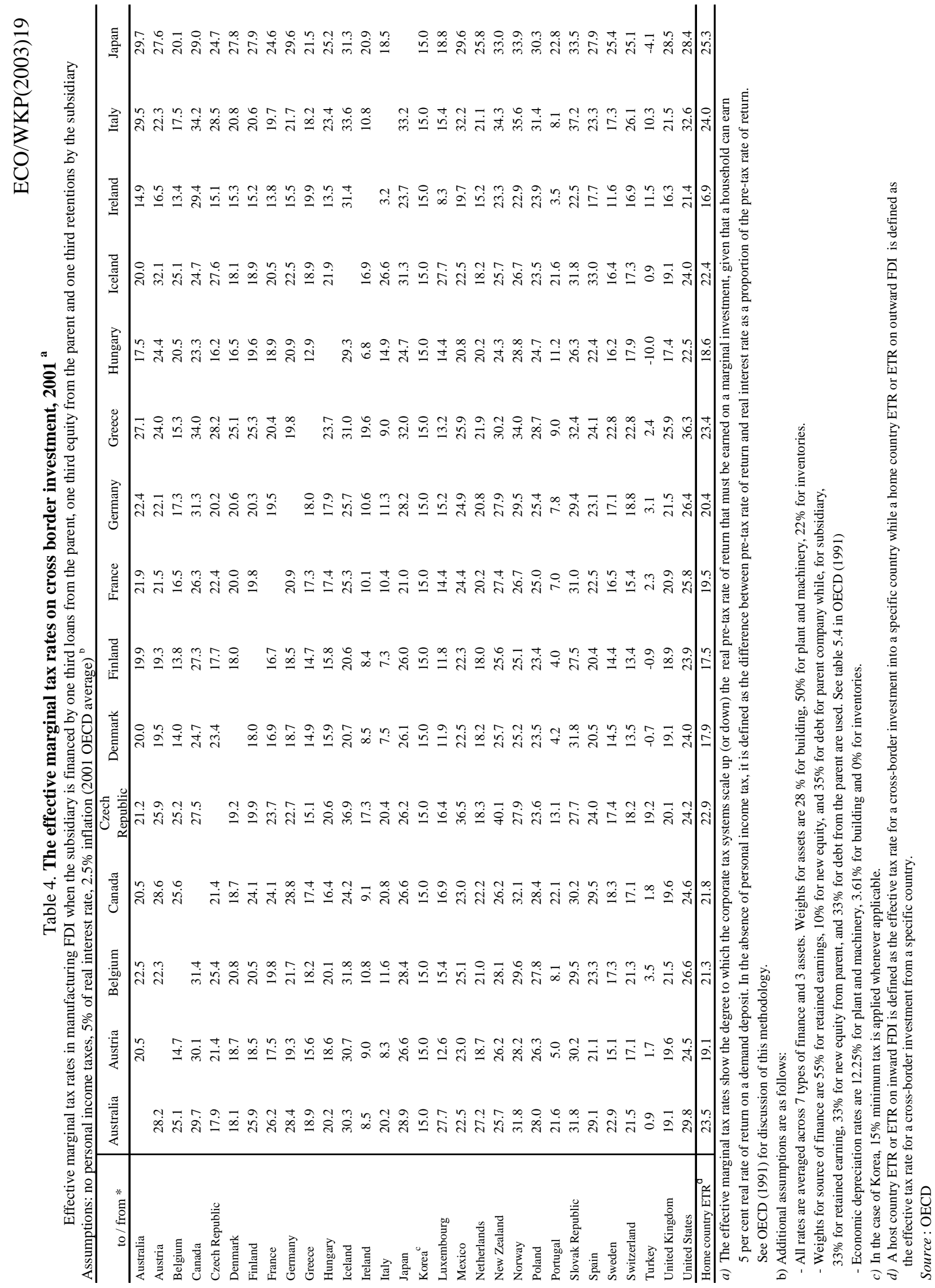




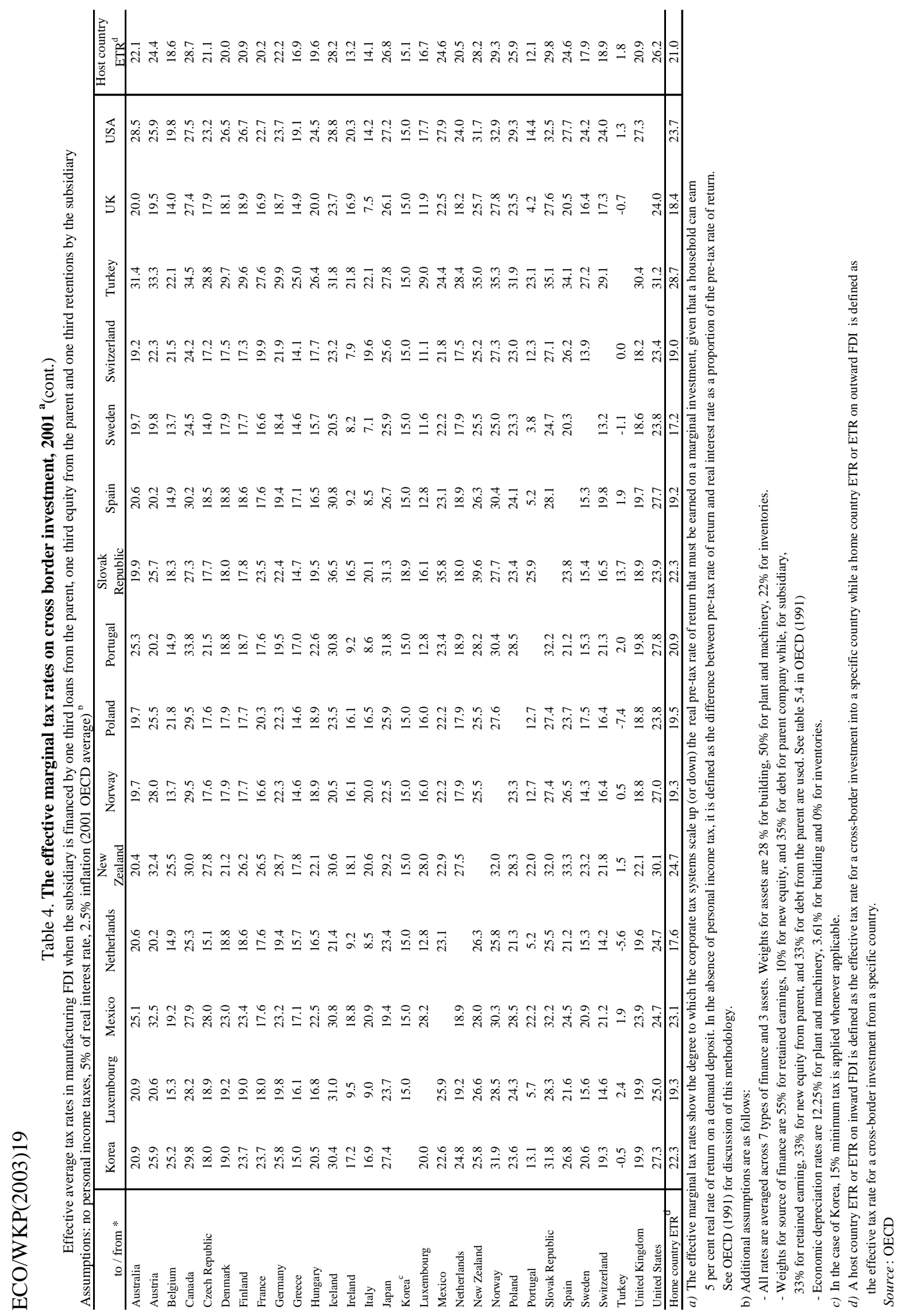




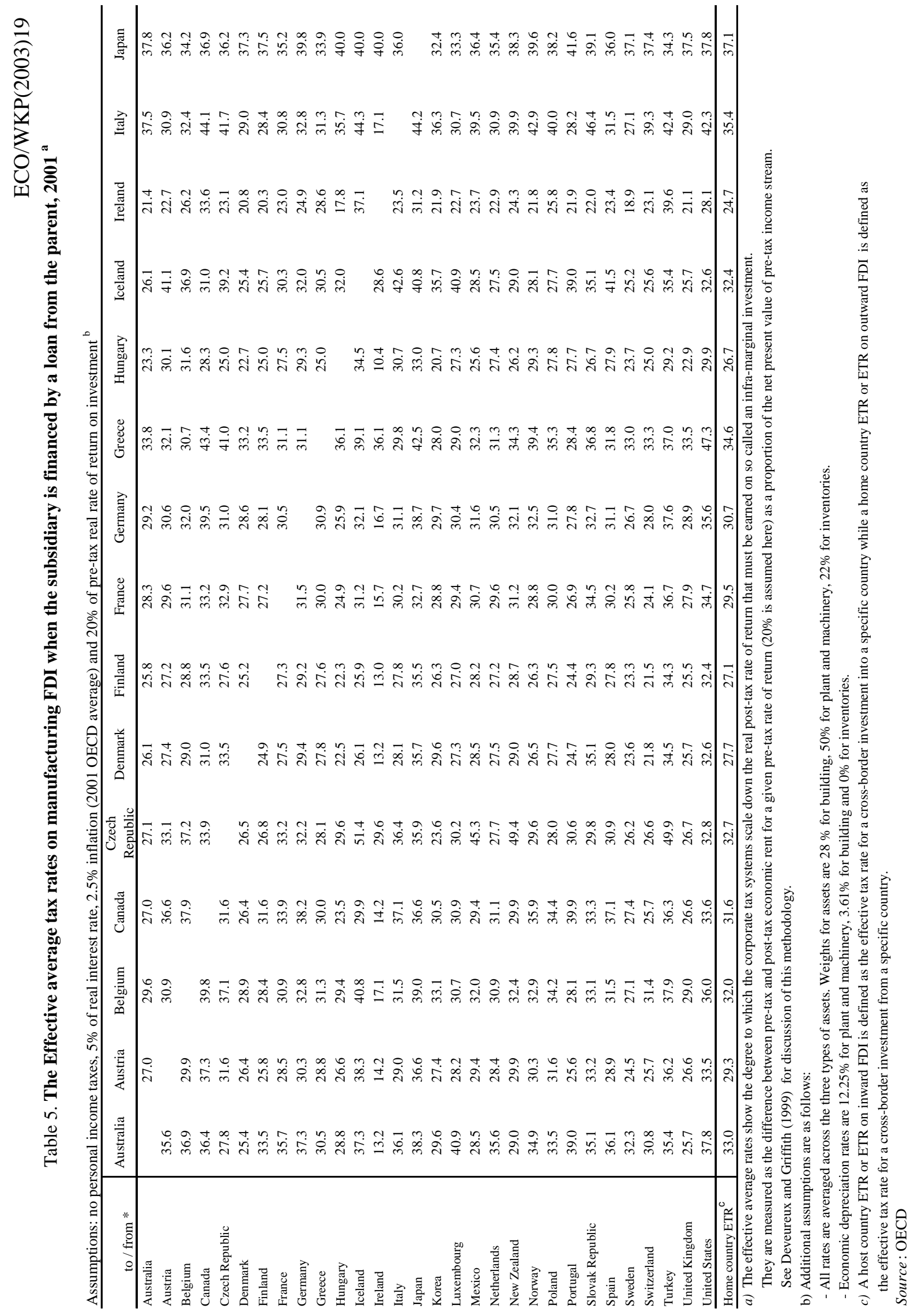




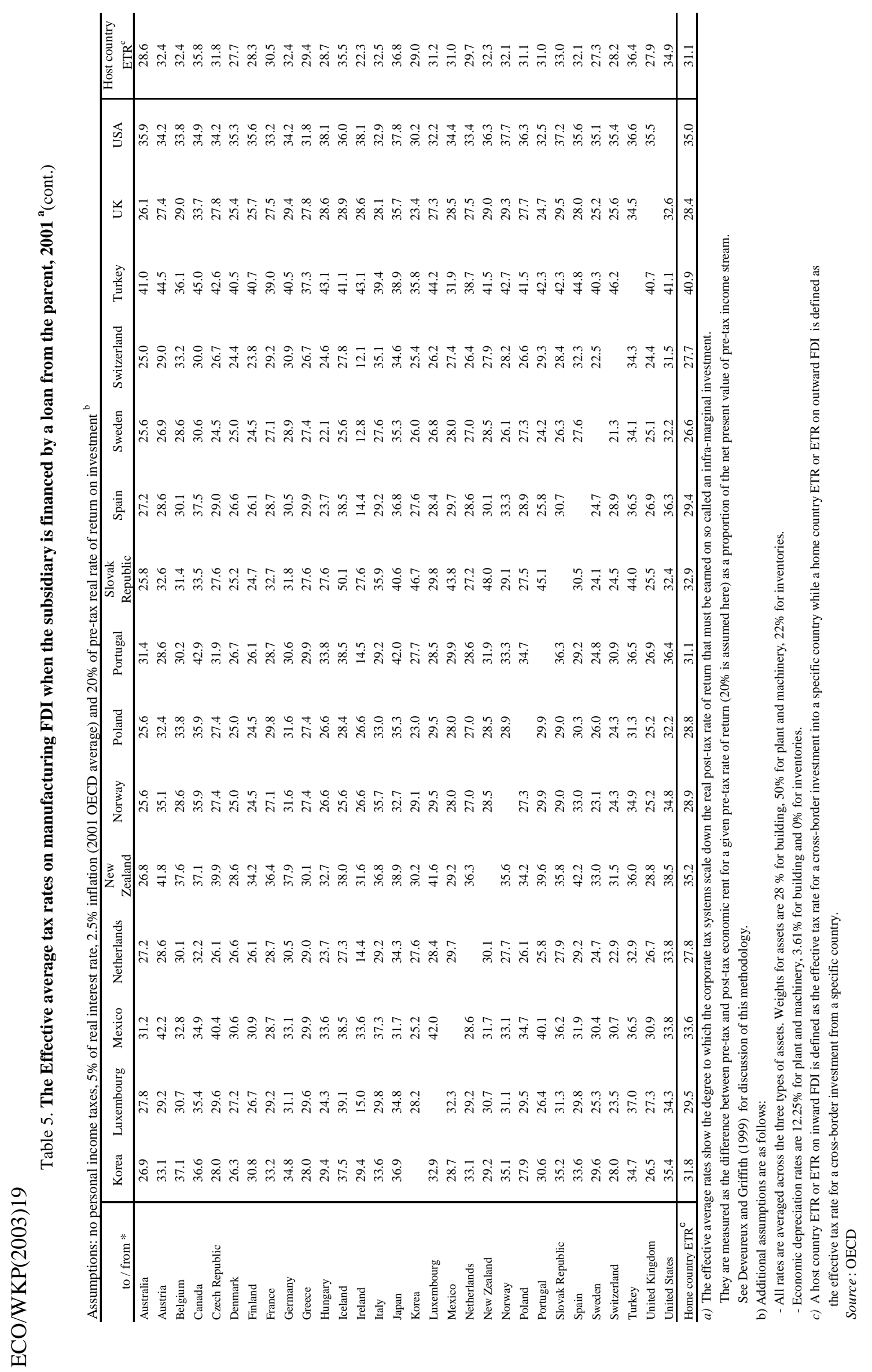




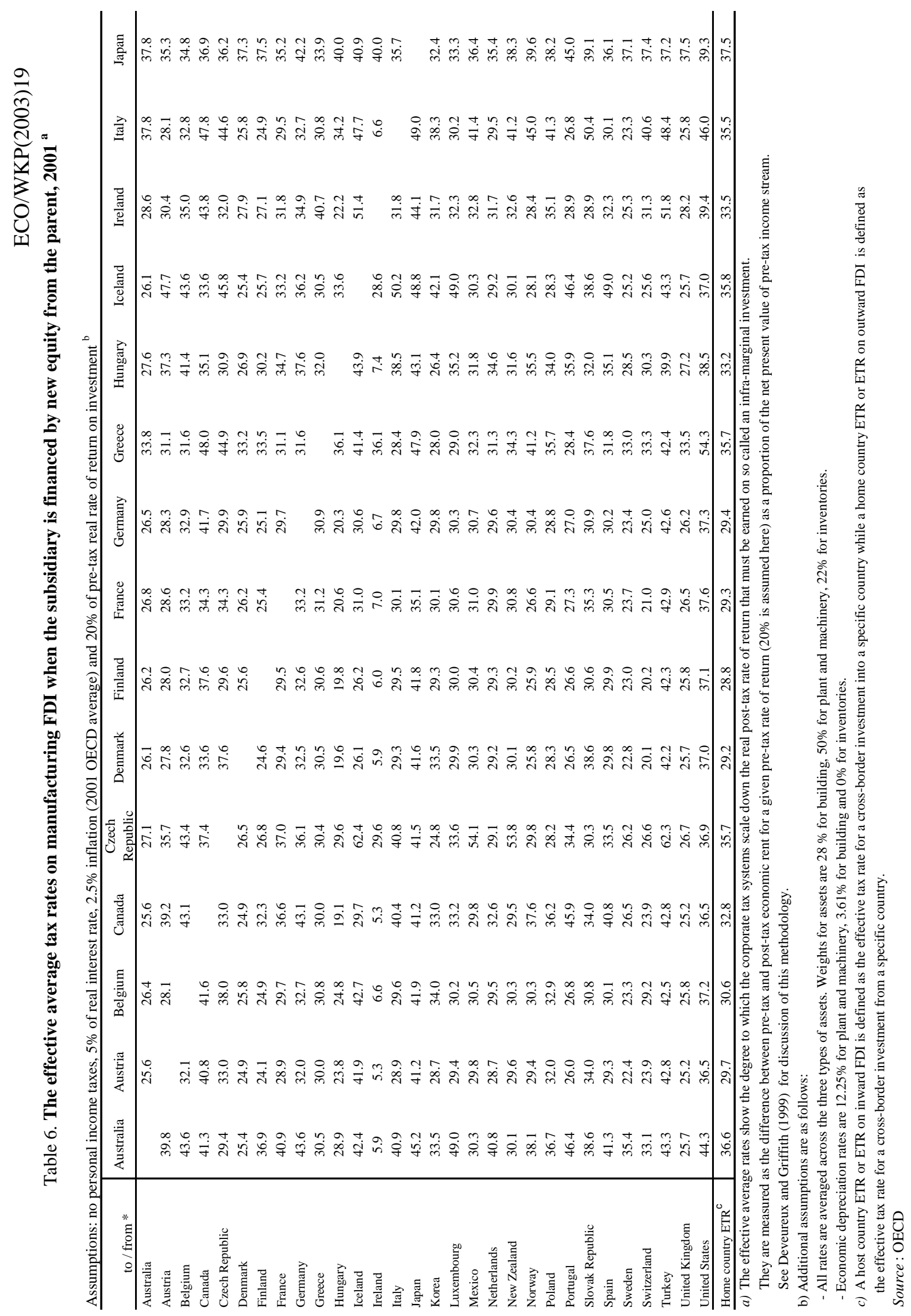




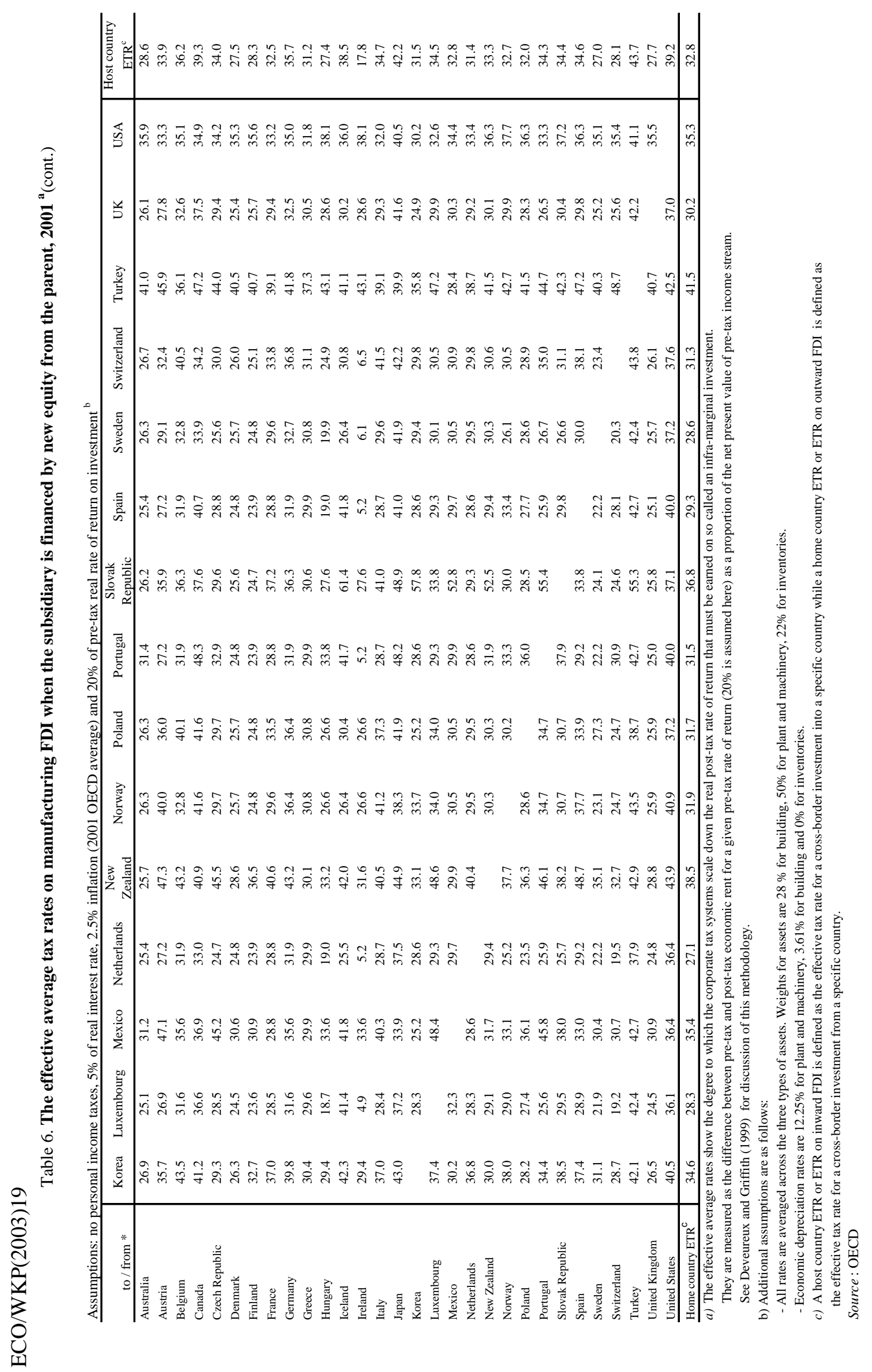




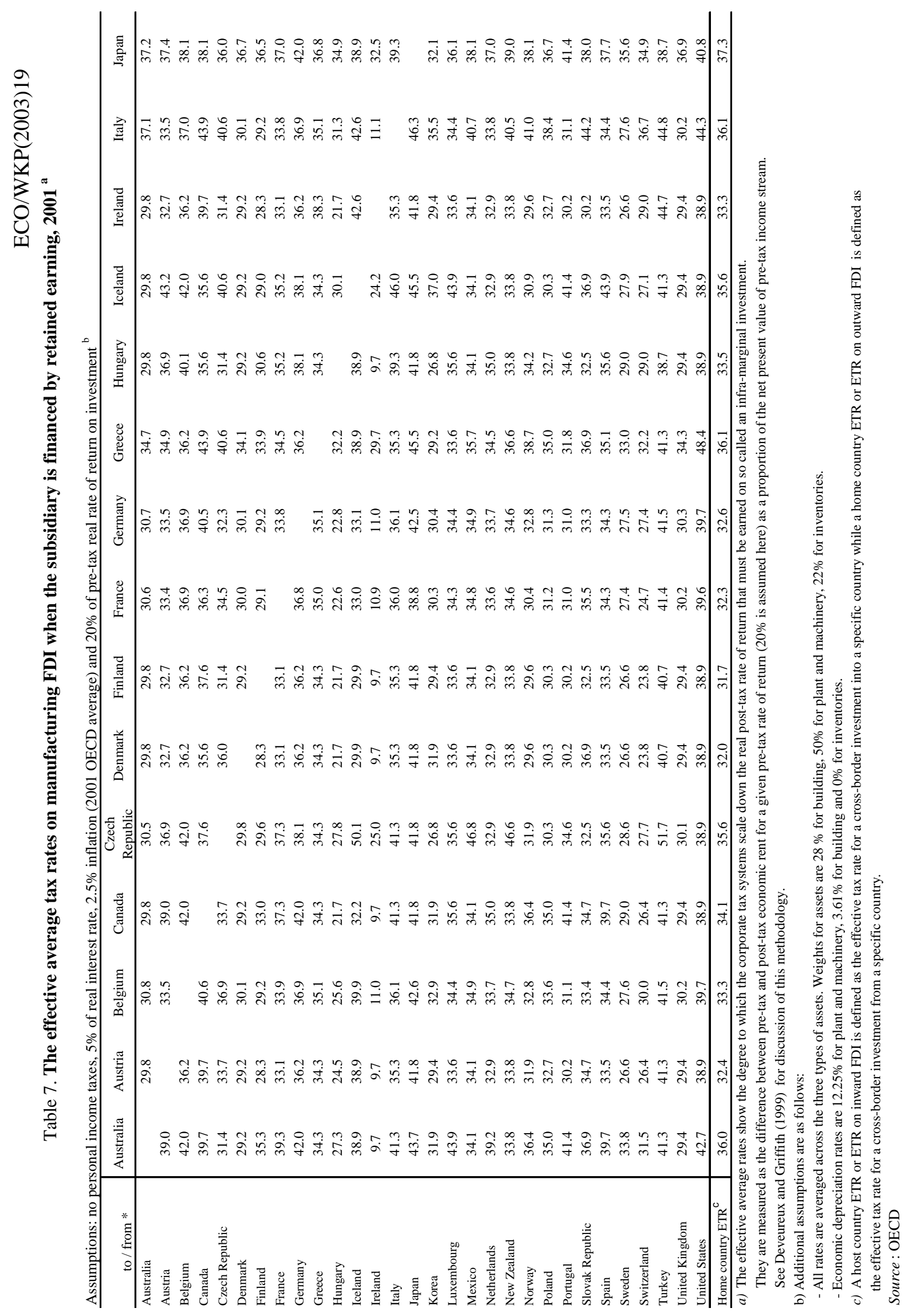

$\hat{\imath}$ 


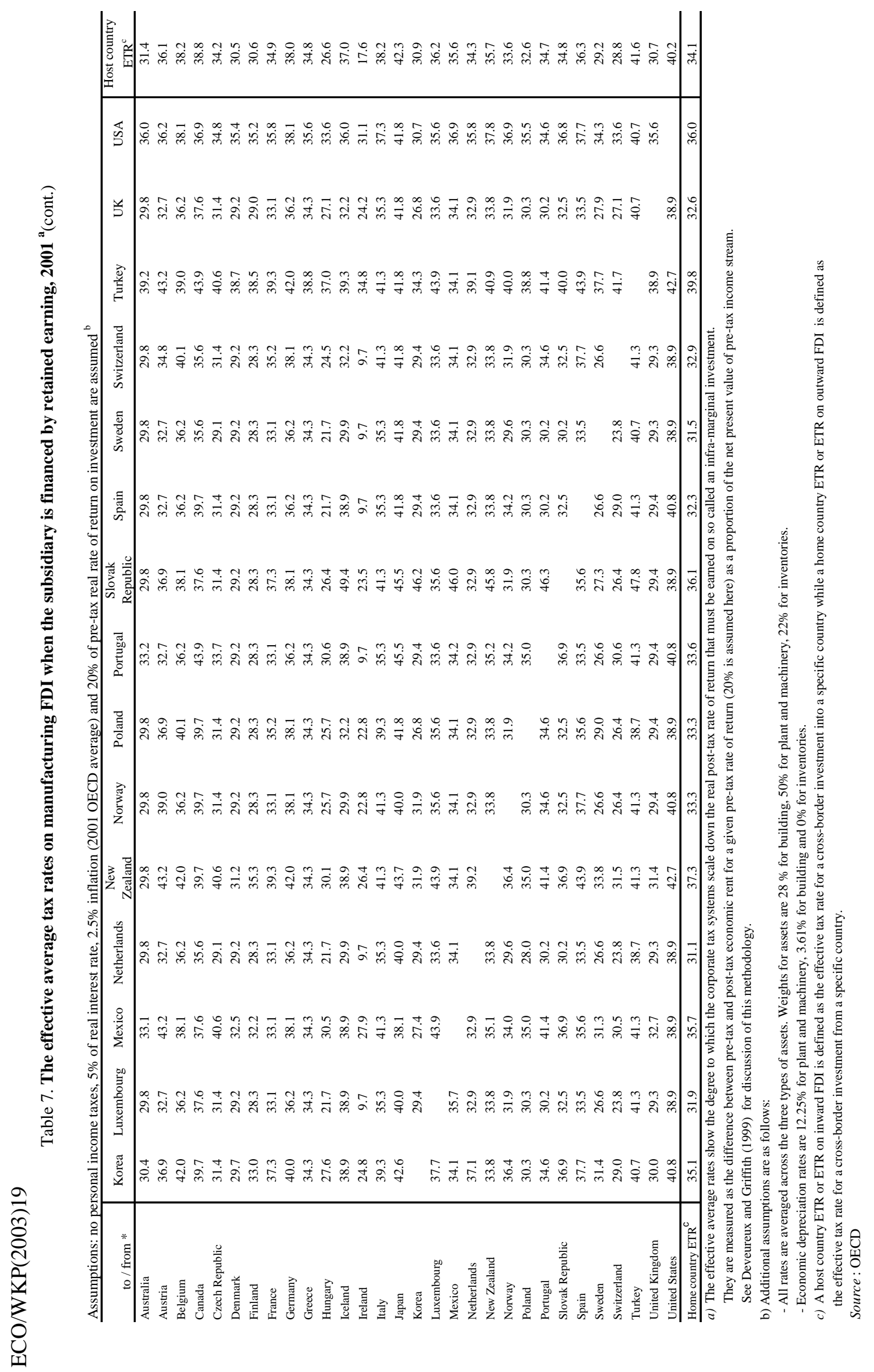




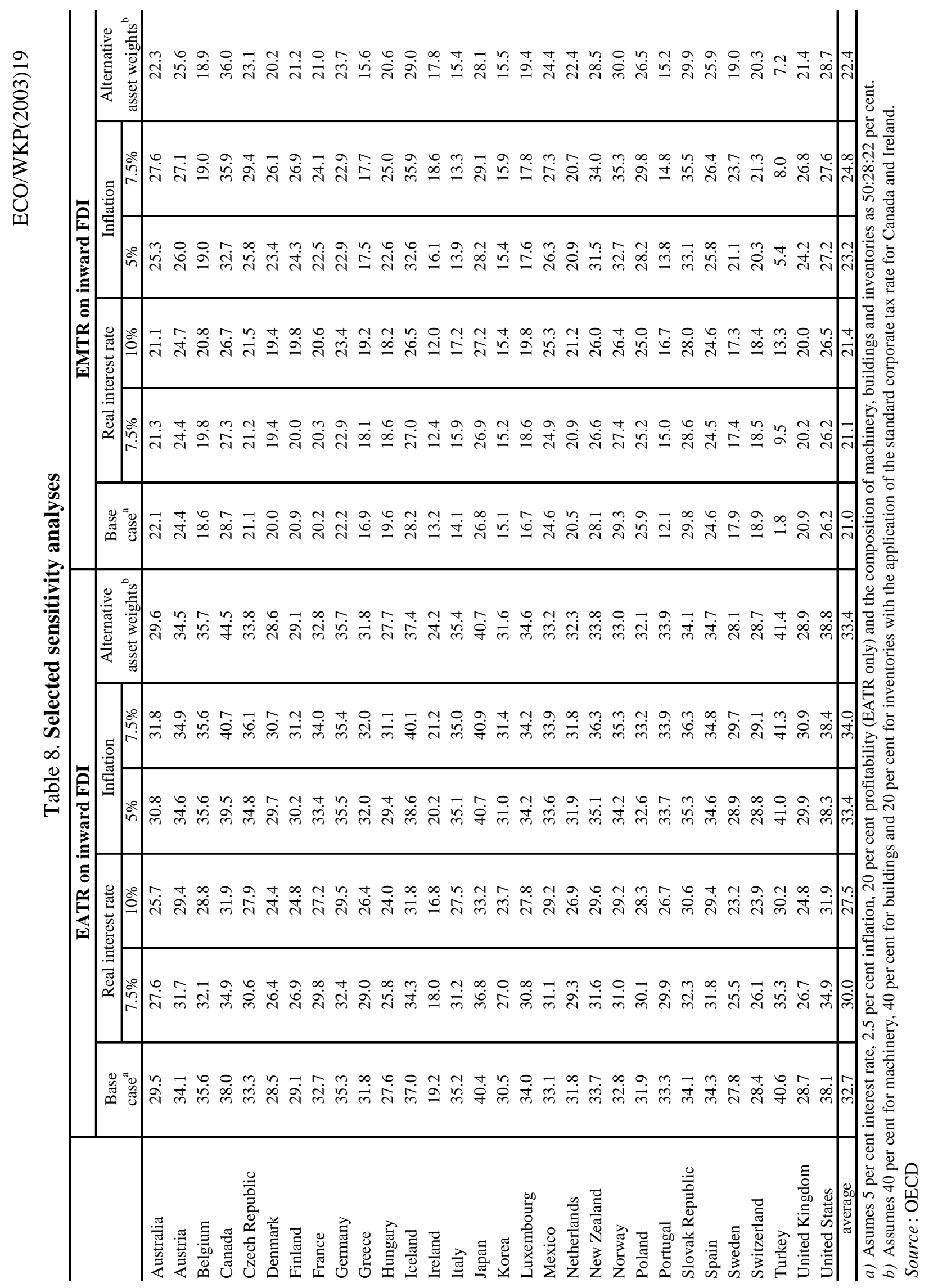




\section{Figure 1. The effective tax rates on inward and outward FDI ${ }^{1}$}

Panel A. Effective marginal tax rates on inward FDI ${ }^{2}$

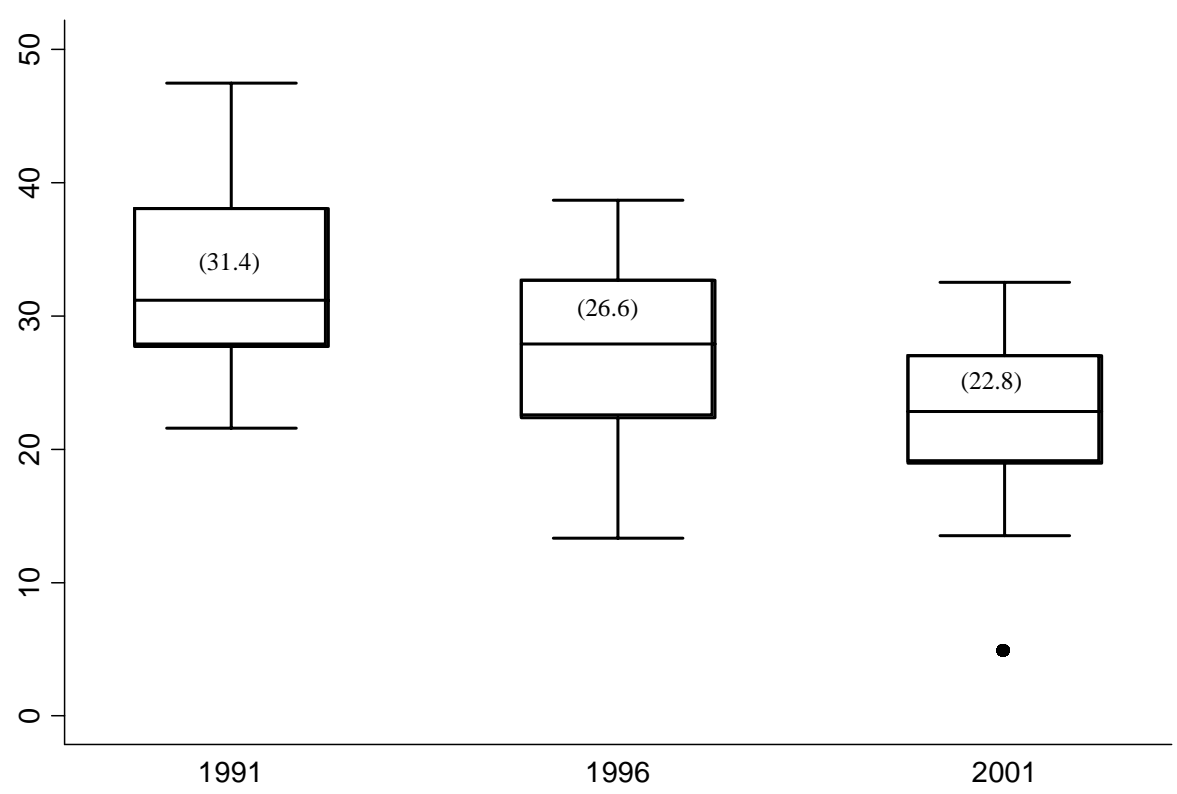

Panel B. Effective average tax rates on inward $\mathrm{FDI}^{2}$

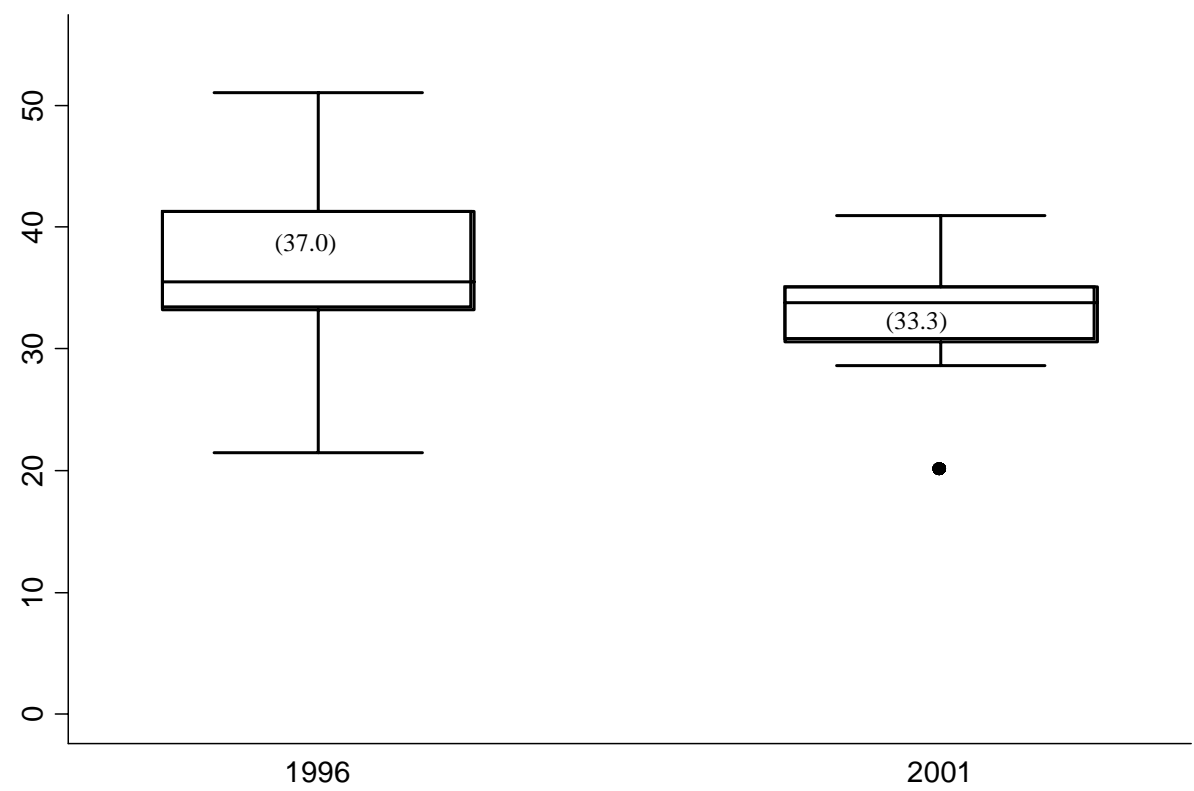

1. An effective tax rate on inward FDI refers to the rate applied to investors in the average investor country on income earned in a host country. An effective marginal rate applies to a marginal investment that earns the minimum rate of return after tax, while an effective average rate applies to an infra-marginal investment that earns some economic rent i.e. a project that earns more than the minimum required after-tax rate of return.

2. The box plot shows, in each year, the median OECD value of the effective tax rate imposed on inward FDI (the horizontal line in the box), the third and second quartiles of the cross-country distribution (the edges of each box) and the extreme values (the two whiskers extending from the box). Averages are provided in parentheses. Dots identify outlier observations. 2001 figures are based on 4.5 per cent inflation to ensure the consistency.

Source: OECD 
Figure 1. The effective tax rates on inward and outward FDI $^{1}$ (cont.)

Panel C. Effective marginal tax rates on outward FDI ${ }^{2}$

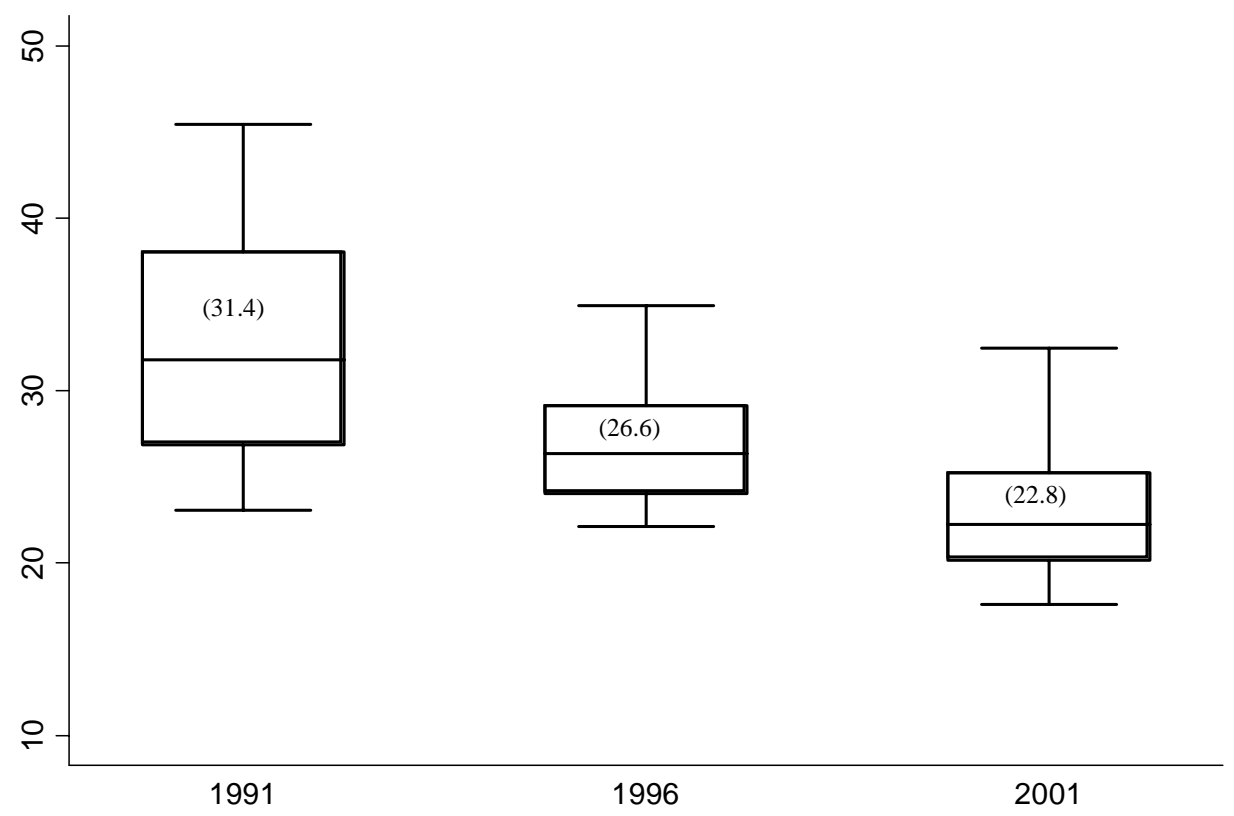

Panel D. Effective average tax rates on outward FDI ${ }^{2}$

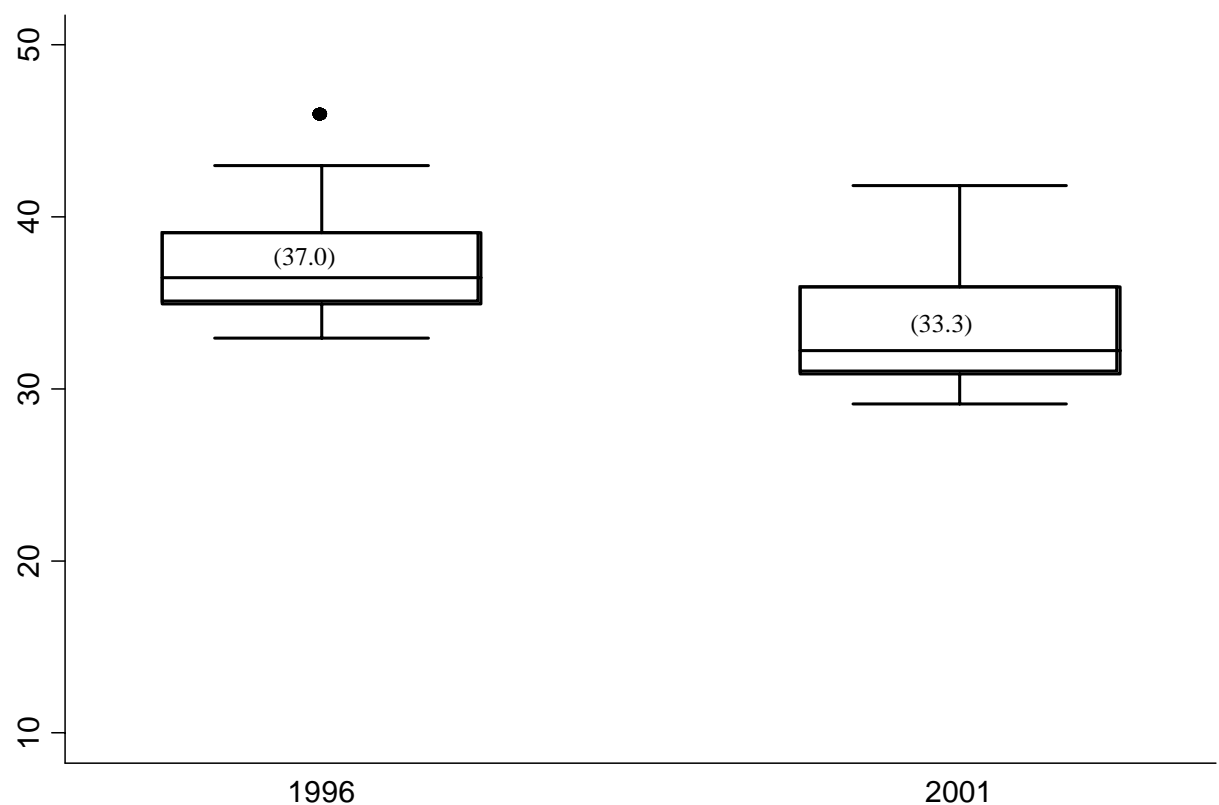

1. An effective tax rate on outward FDI refers to the rate applied by a home country for investing in the average host country. An effective marginal rate applies to a marginal investment that earns minimum rate of return after tax, while an effective average rate applies to an infra-marginal investment that earns some economic rent i.e. a project that earns more than the minimum required after-tax rate of return.

2. The box plot shows, in each year, the median OECD value of the effective tax rate imposed on outward FDI (the horizontal line in the box), the third and second quartiles of the cross-country distribution (the edges of each box) and the extreme values (the two whiskers extending from the box). Averages are provided in parentheses. Dots identify outlier observations. 2001 figures are based on 4.5 per cent inflation to ensure the consistency.

Source: OECD 
Figure 2. Variation of the effective tax rates on inward FDI applied by host country, 2001 ${ }^{1}$

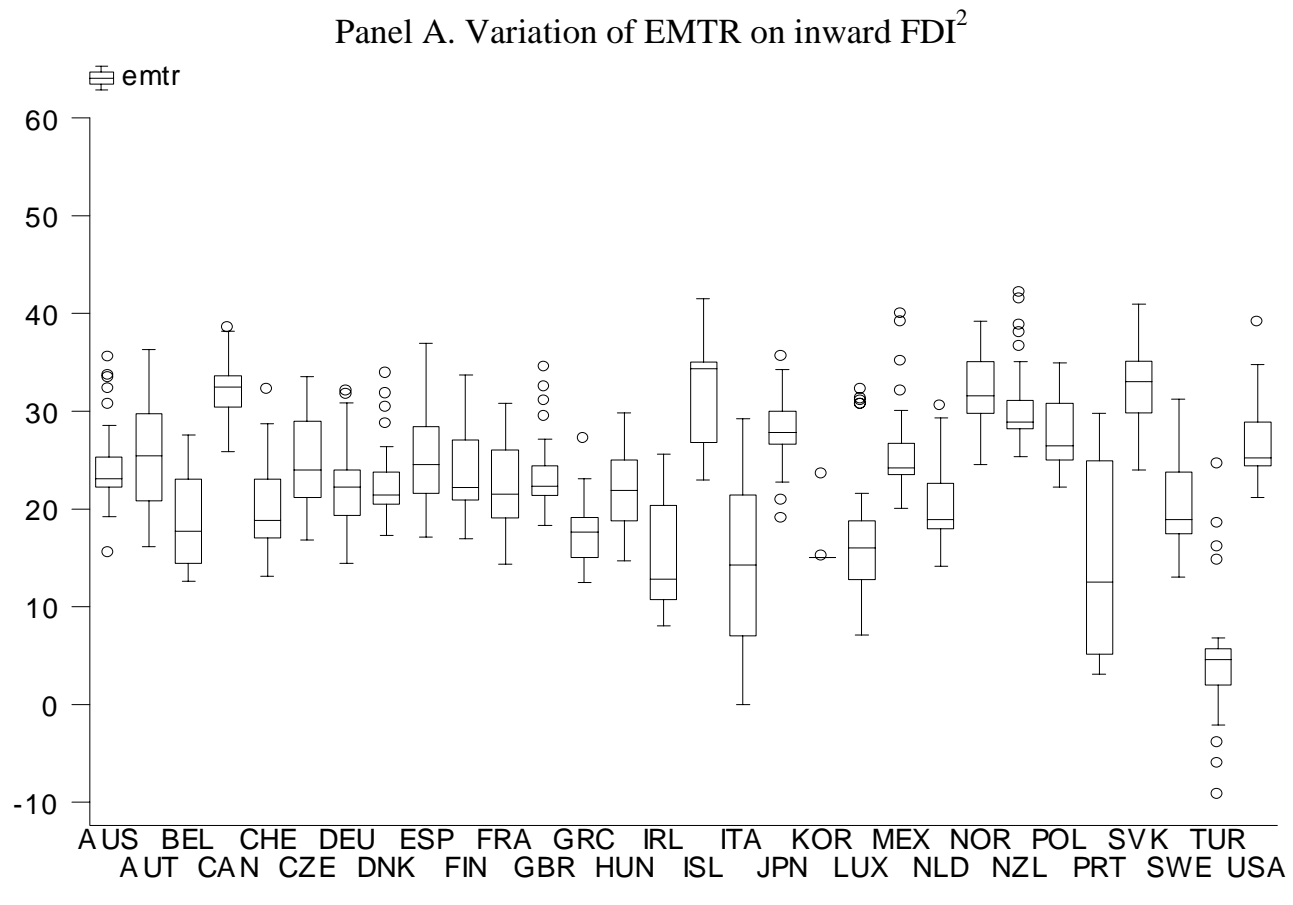

Panel B. Variation of EATR on inward $\mathrm{FDI}^{2}$

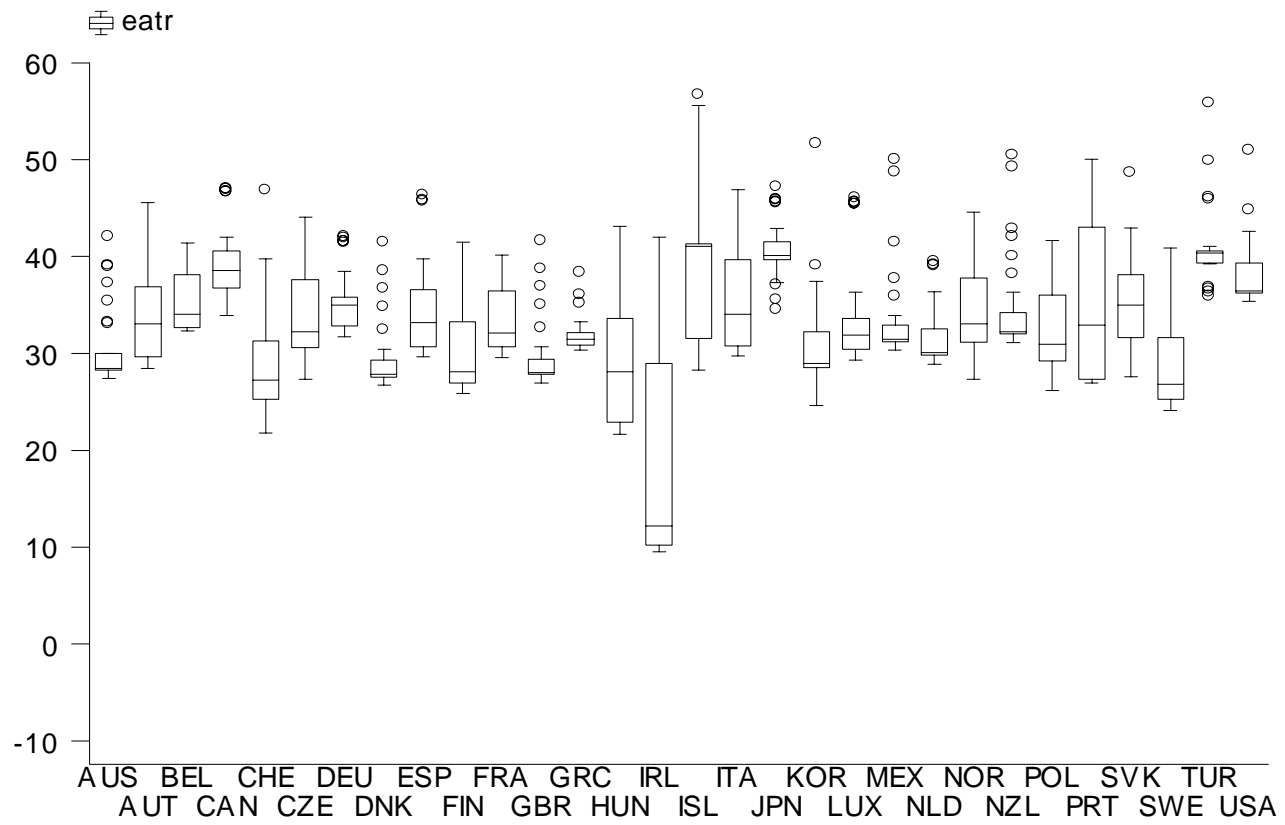

1. An effective tax rate on inward FDI refers to the rate applied to investors in the average investor country on income earned in a host country. An effective marginal rate applies to a marginal investment that earns the minimum rate of return after tax, while an effective average rate applies to an infra-marginal investment that earns some economic rent i.e. a project that earns more than the minimum required after-tax rate of return.

2. The box plot shows, for each host country, the variation of EMTR or EATR imposed on the investment from other countries. The median value of the effective tax rate is depicted by the horizontal line in the box, the third and second quartiles of the cross-country distribution by the edges of each box and the extreme values by the two whiskers extending from the box. Dots identify outlier observations.

Source: OECD 
Figure 3. Variation of the effective tax rates on outward FDI applied by host country, 2001 ${ }^{1}$
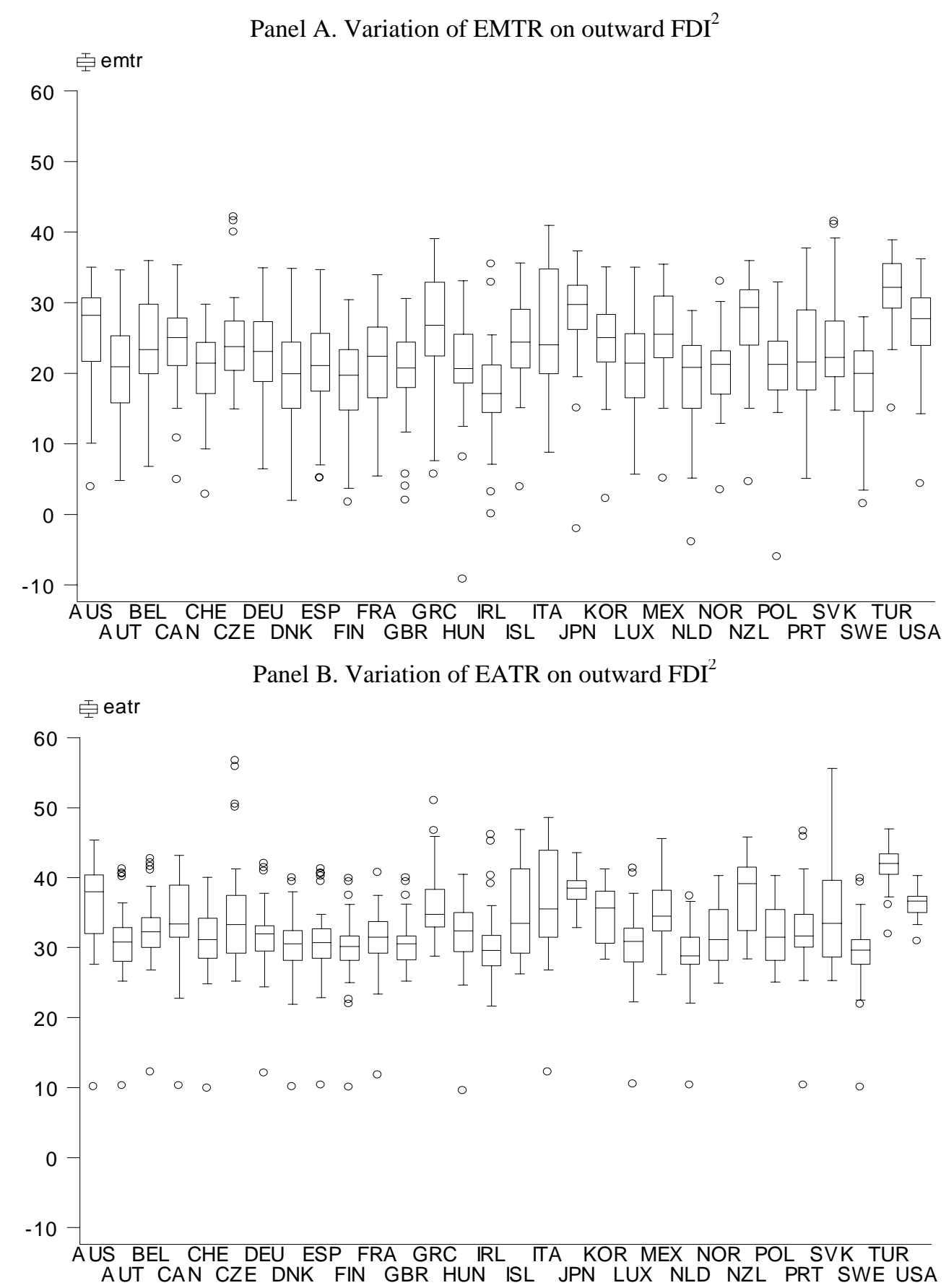

1. An effective tax rate on outward FDI refers to the rate applied by a home country for investing in the average host country. An effective marginal rate applies to a marginal investment that earns minimum rate of return after tax, while an effective average rate applies to an infra-marginal investment that earns some economic rent i.e. a project that earns more than the minimum required after-tax rate of return.

2. The box plot shows, for each investor country, the variation of EMTR or EATR faced by its residents in other countries. The median value of the effective tax rate is depicted by the horizontal line in the box, the third and second quartiles of the cross-country distribution by the edges of each box and the extreme values by the two whiskers extending from the box. Dots identify outlier observations. Source: OECD 
Figure 4. Change in effective tax rates on inward FDI measured relative to the OECD average ${ }^{1}$

Panel A: Change in EMTR

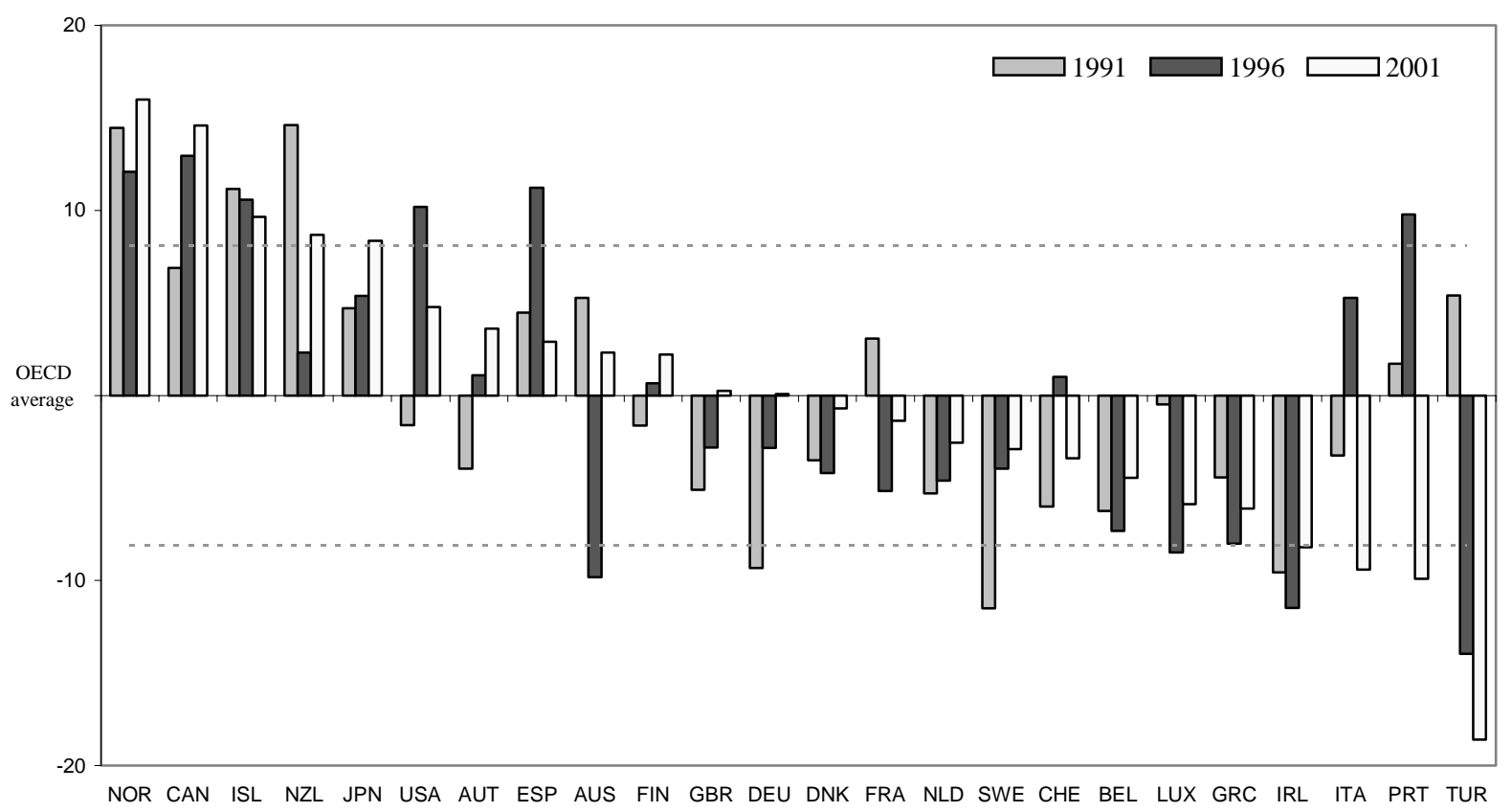

Panel B: Change in EATR

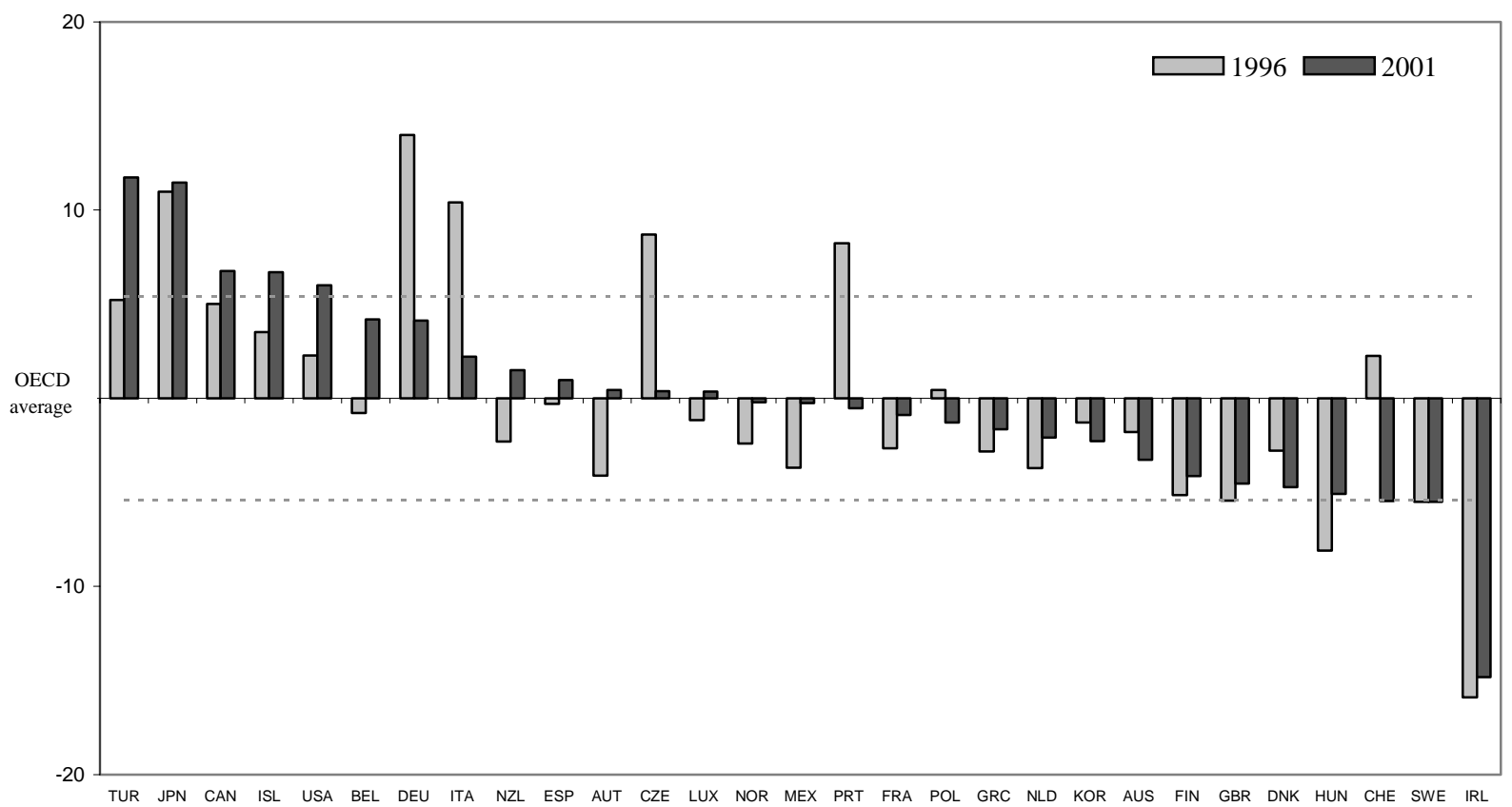

1. An effective tax rate on inward FDI refers to the rate applied to investors in the average investor country on income earned in a host country. An effective marginal rate applies to a marginal investment that earns the minimum rate of return after tax, while an effective average rate applies to an infra-marginal investment that earns some economic rent i.e. a project that earns more than the minimum required after-tax rate of return. The rate is measured as a deviation from the OECD average. Dotted lines in the graphs indicate the interval of one standard deviation (2001). Source: OECD 
Figure 5. Change in effective tax rates on outward FDI measured relative to the OECD average ${ }^{1}$

Panel A: Change in EMTR

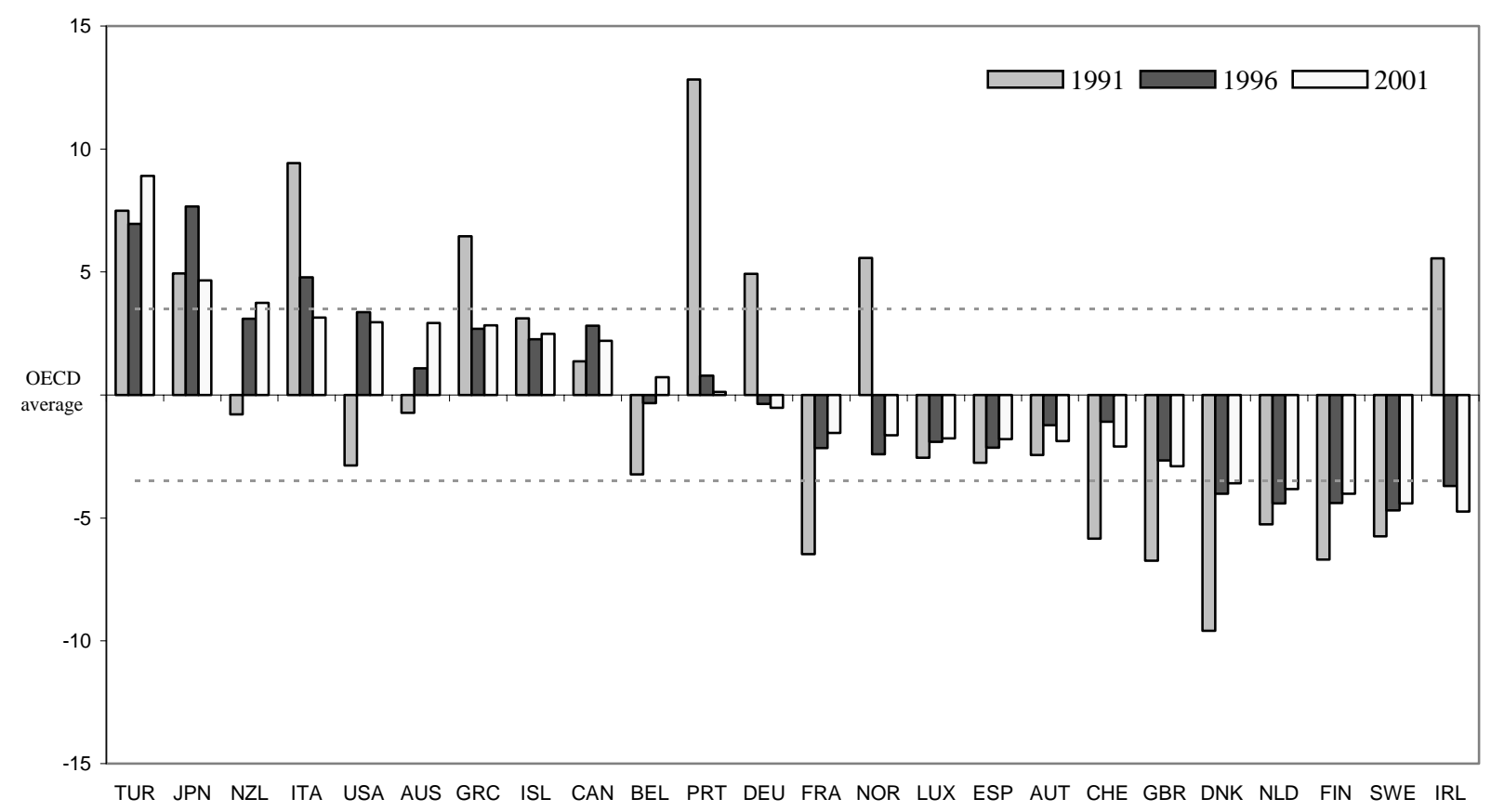

Panel B: Change in EATR

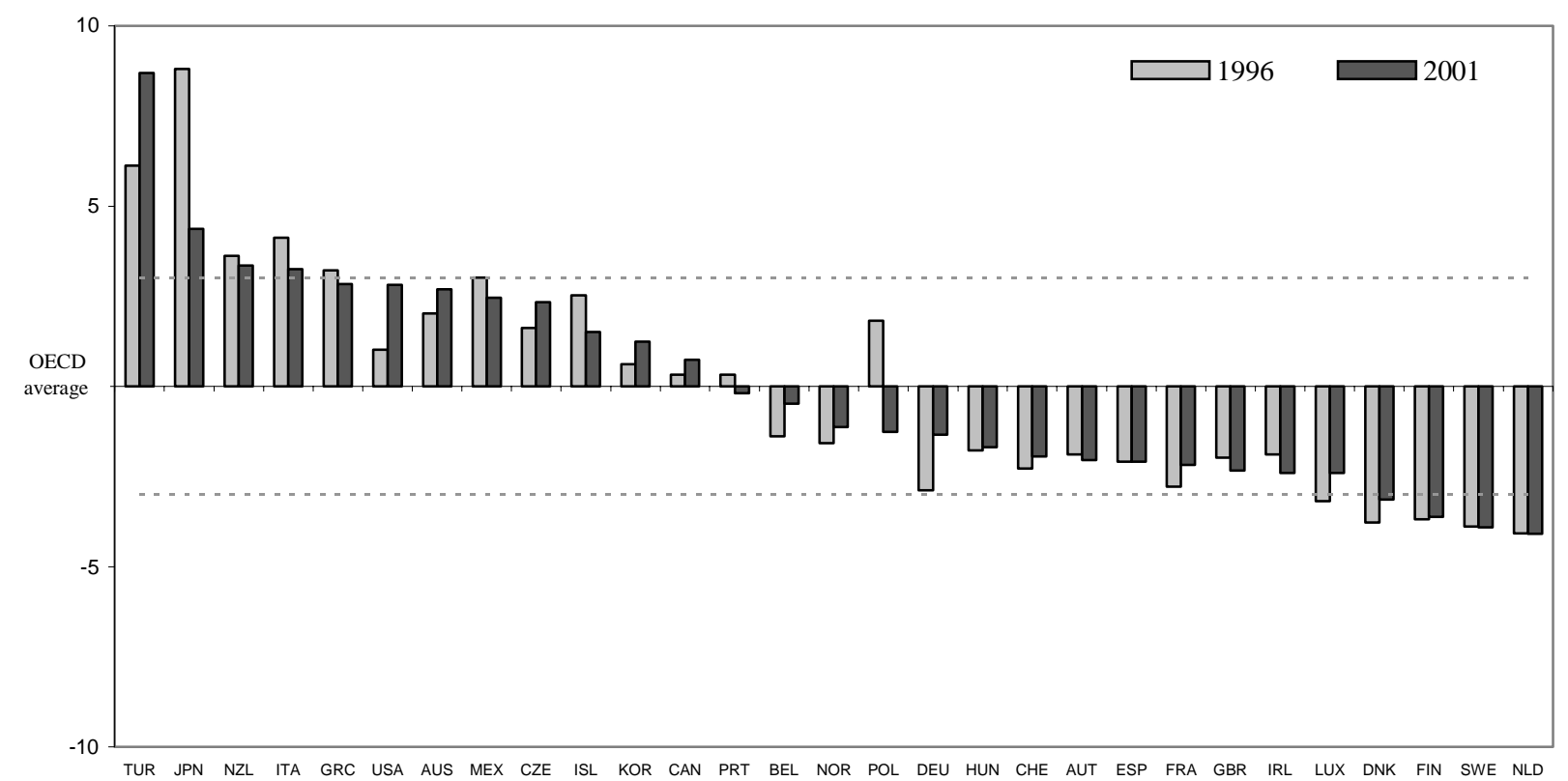

1. An effective tax rate on outward FDI refers to the rate applied by a home country for investing in the average host country. An effective marginal rate applies to a marginal investment that earns minimum rate of return after tax, while an effective average rate applies to an infra-marginal investment that earns some economic rent i.e. a project that earns more than the minimum required after-tax rate of return. The rate measured as a deviation from the OECD average. Dotted lines in the graphs indicate the interval of one standard deviation (2001). Source: OECD 
Figure 6. The EATRs on inward FDI by financing source, $2001^{1}$

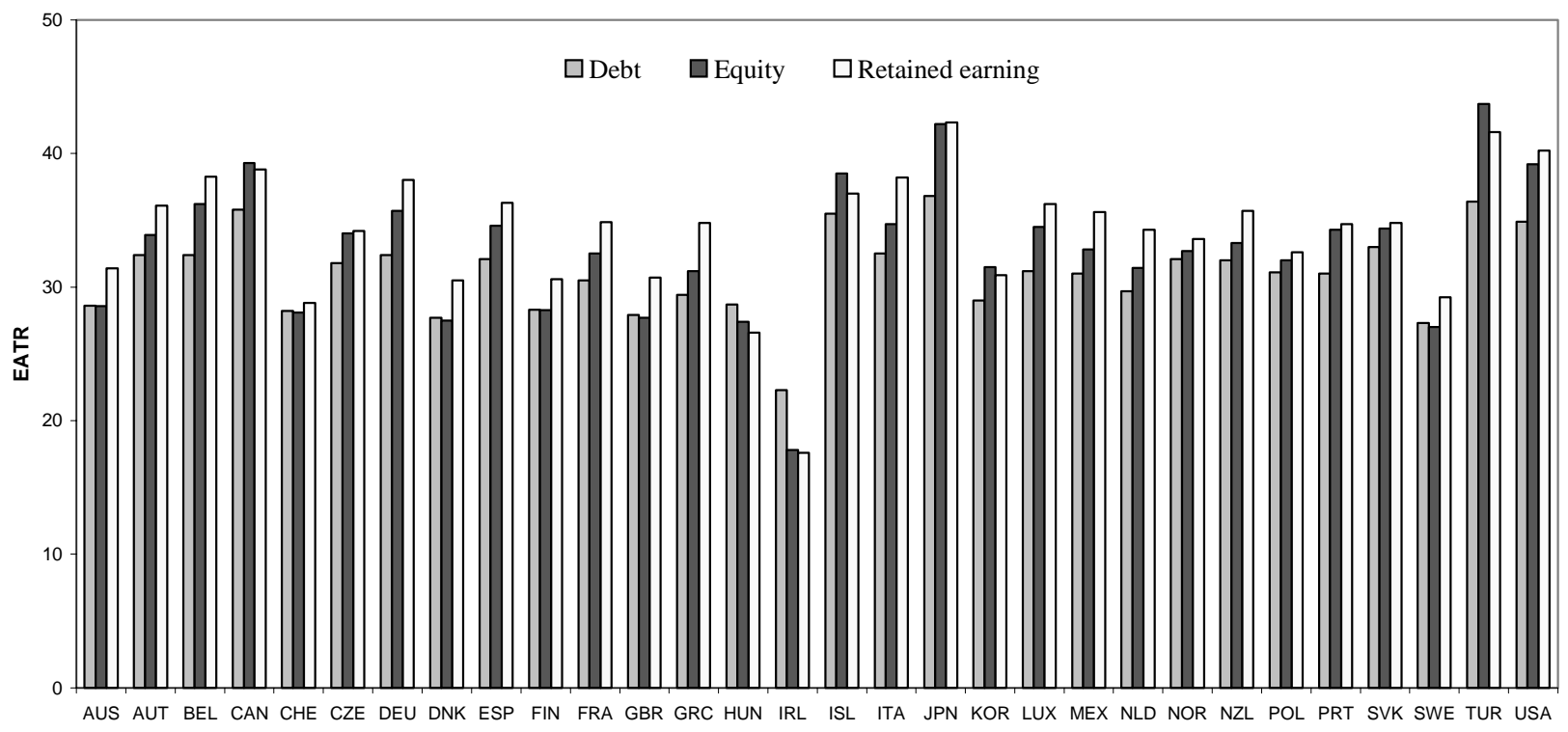

Figure 7. The EATRs by the type of assets, $2001^{1}$

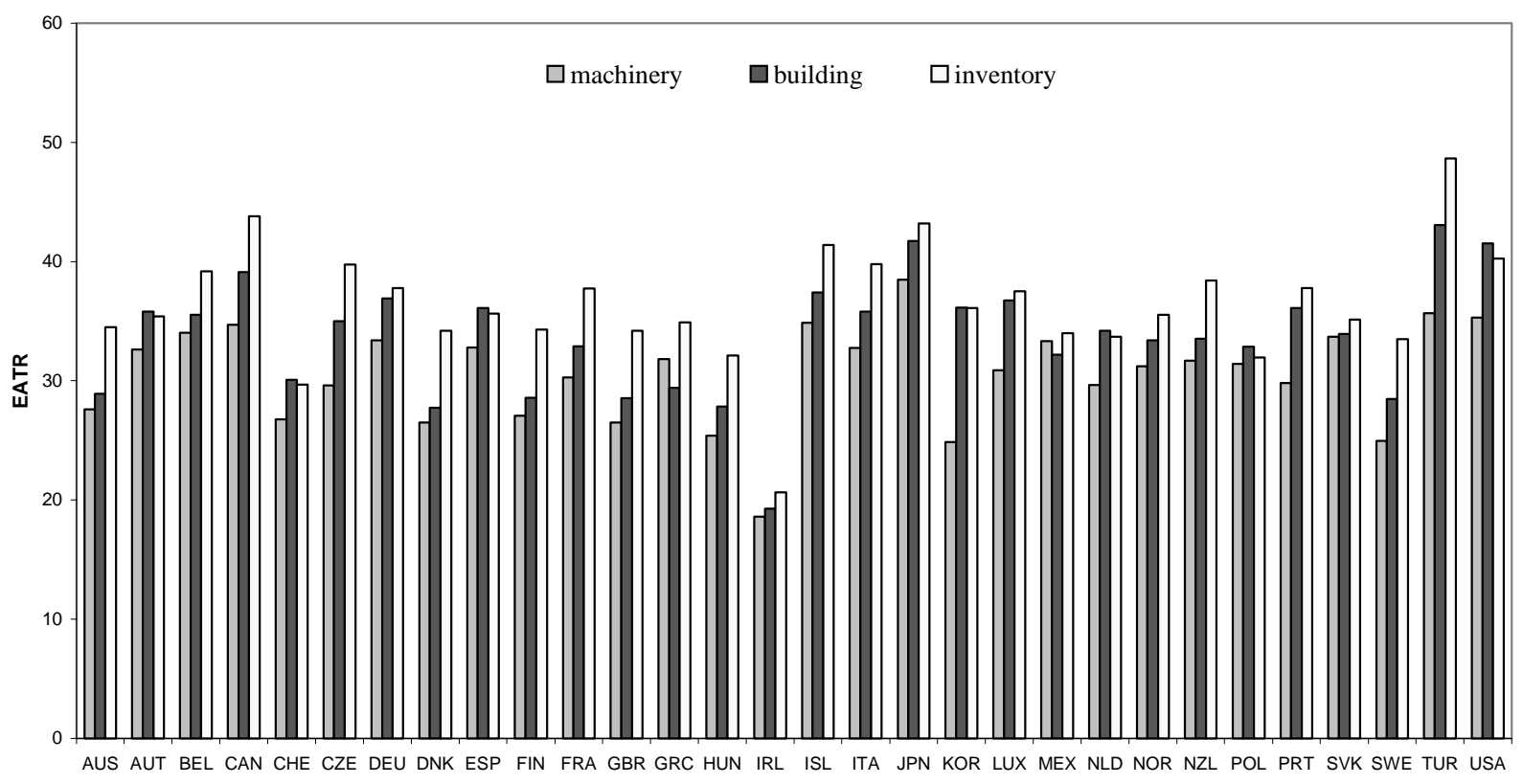

1. An effective average tax rate on inward FDI refers to the rate applied by a host country to the average investor country's infra-marginal investment that earns some economic rent i.e. a project that earns more than the minimum required after-tax rate of return. Source: $\mathrm{OECD}$ 
Figure 8. The EATRs on outward FDI - exemption vs. credit system countries, $2001^{1}$

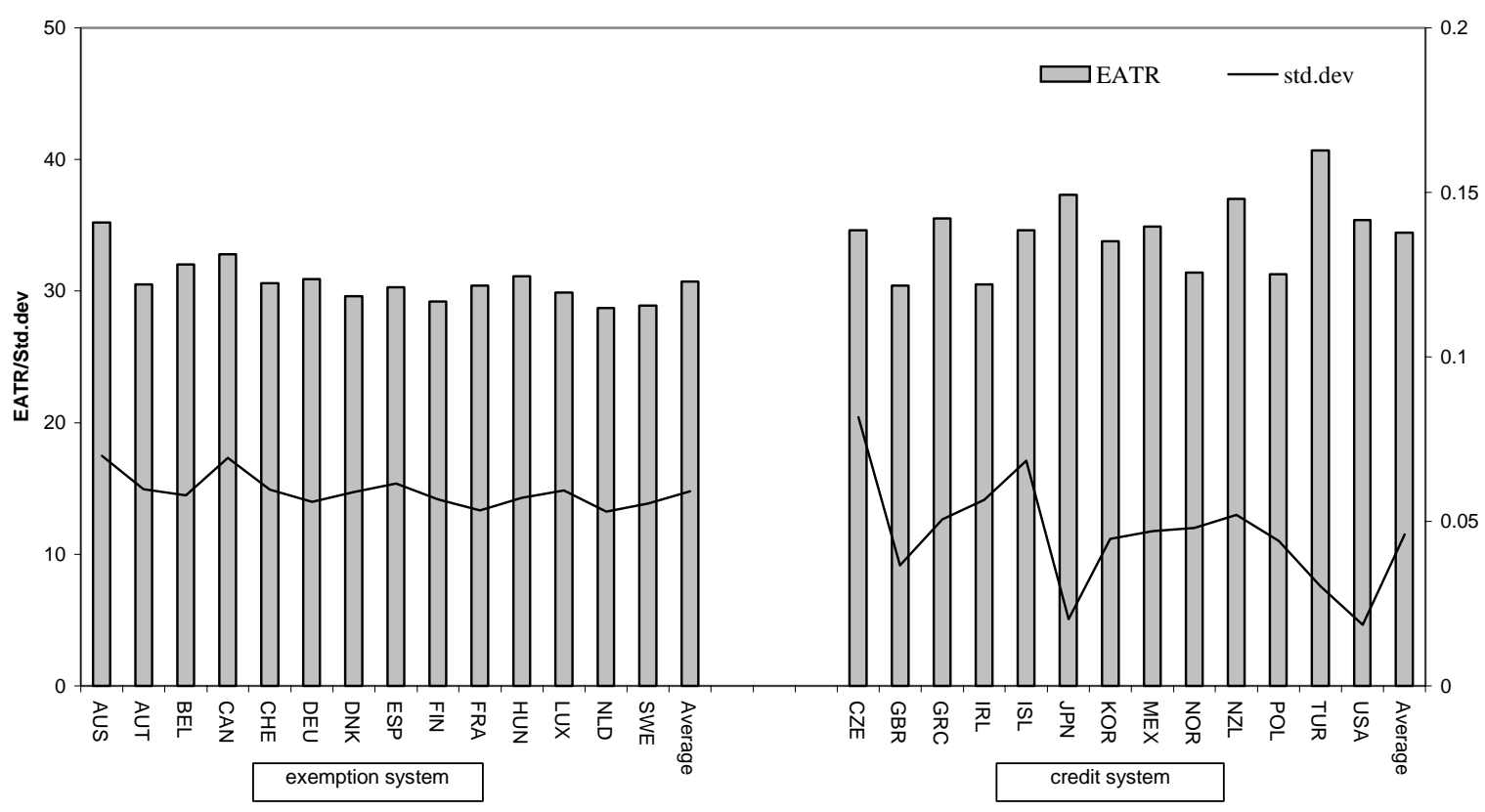

Figure 9. The EATRs on inward FDI by the level of profitability, $2001^{2}$

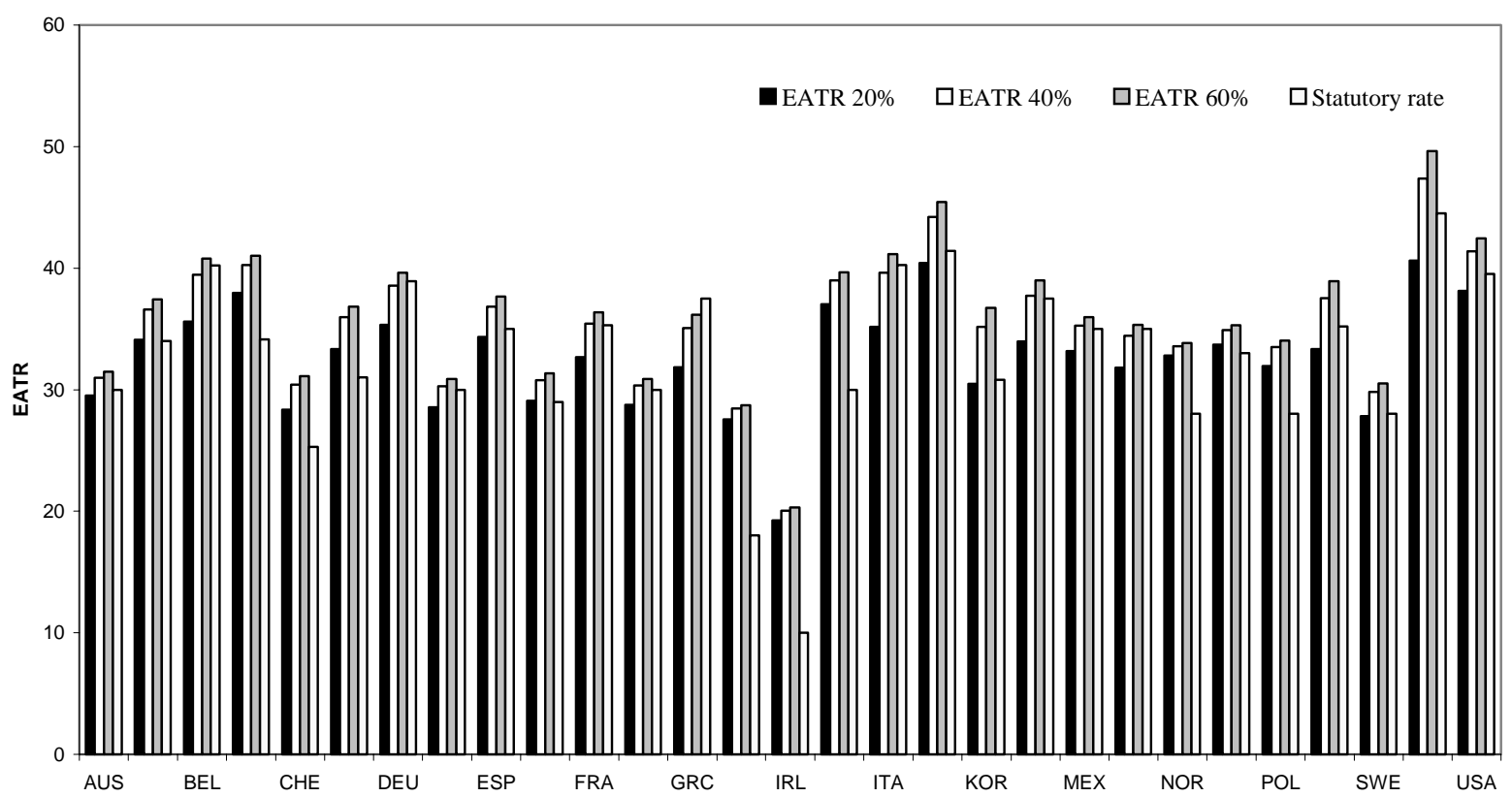

1. An EATR on outward FDI refers to the rate applied by a home country for an infra-marginal investment in the average host country. Exemption system countries exempt tax on foreign-source income while credit system countries grant tax credits for foreign taxes paid by subsidiaries. Italy and Portugal are excluded since they exempt taxes for EU countries, but partially exempt or provide credits for non-EU countries.

2. An effective average tax rate on inward FDI refers to the rate applied by a host country to the average investor country's infra-marginal investment that earns some economic rent i.e. a project that earns more than the minimum required after-tax rate of return. The profitability is defined as pre-tax real rate of return on investment.

Source: OECD 


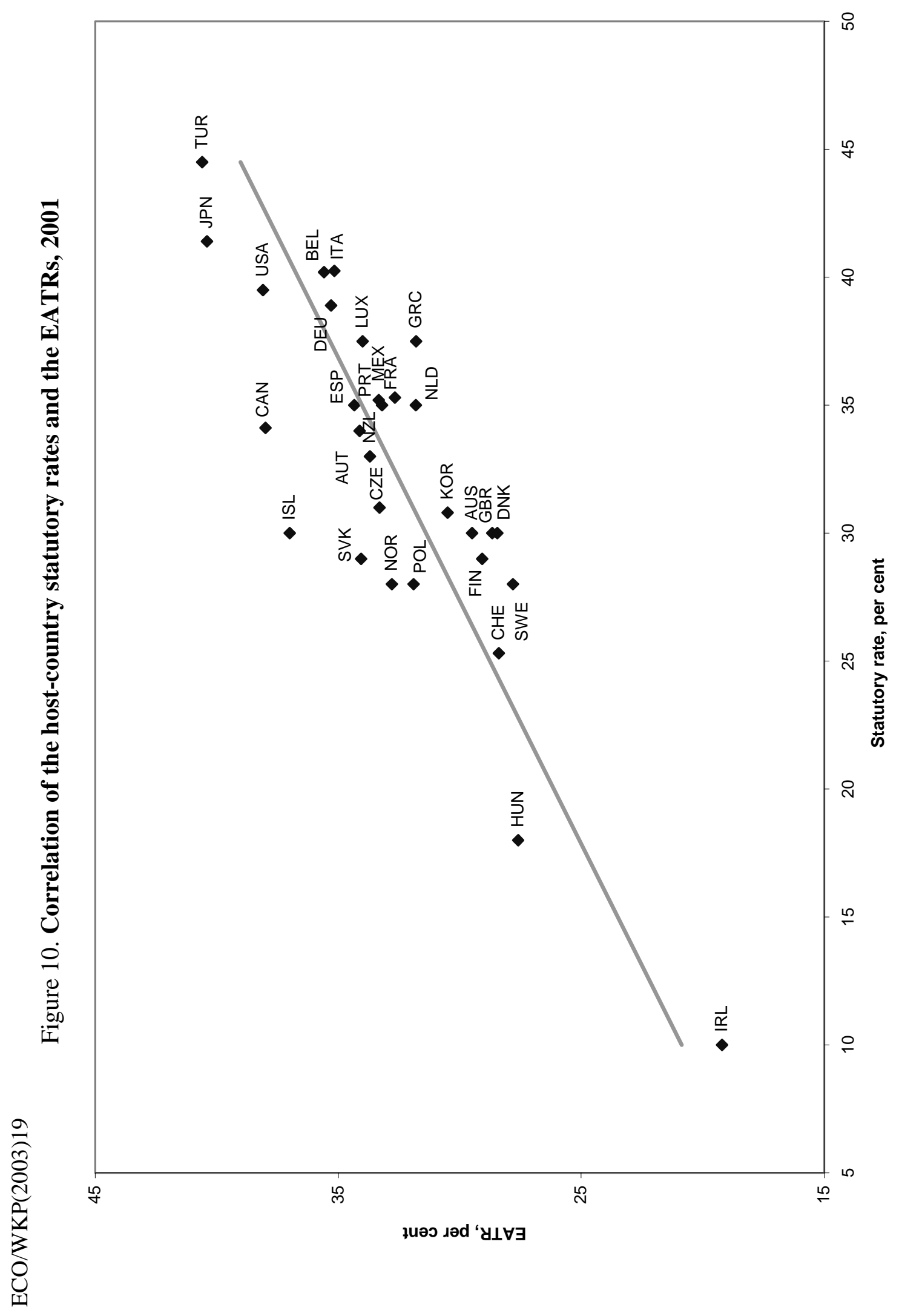

0
0
0
0
0
$\vdots$
$\vdots$
0 
Figure 11. The EATRs on inward FDI and the ATRs on capital, $1996{ }^{1}$

Panel A: Carey et al (2000)'s ATR based on net operating surplus

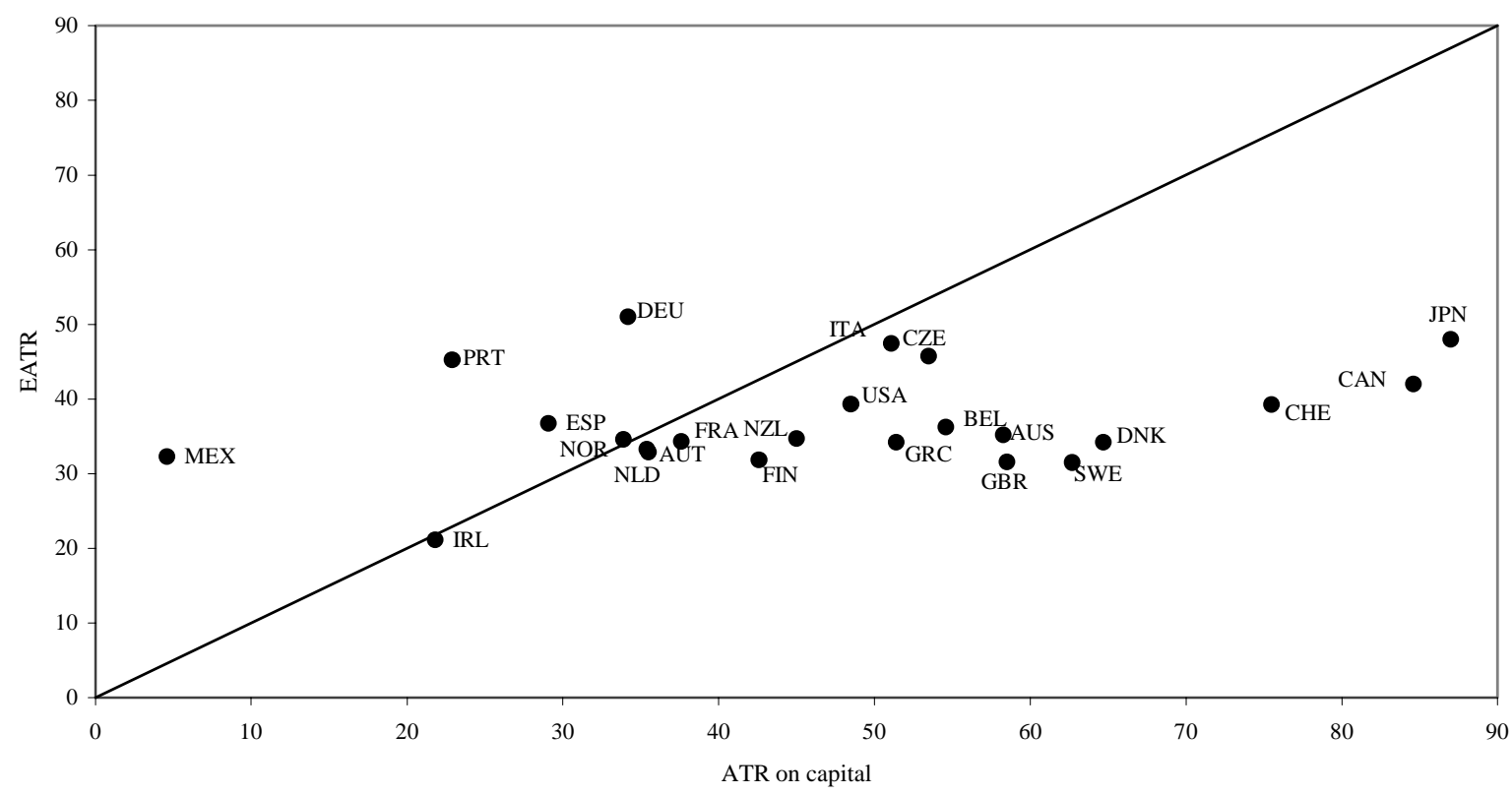

Panel B: Carey et al (2000)'s ATRs based on gross operating surplus

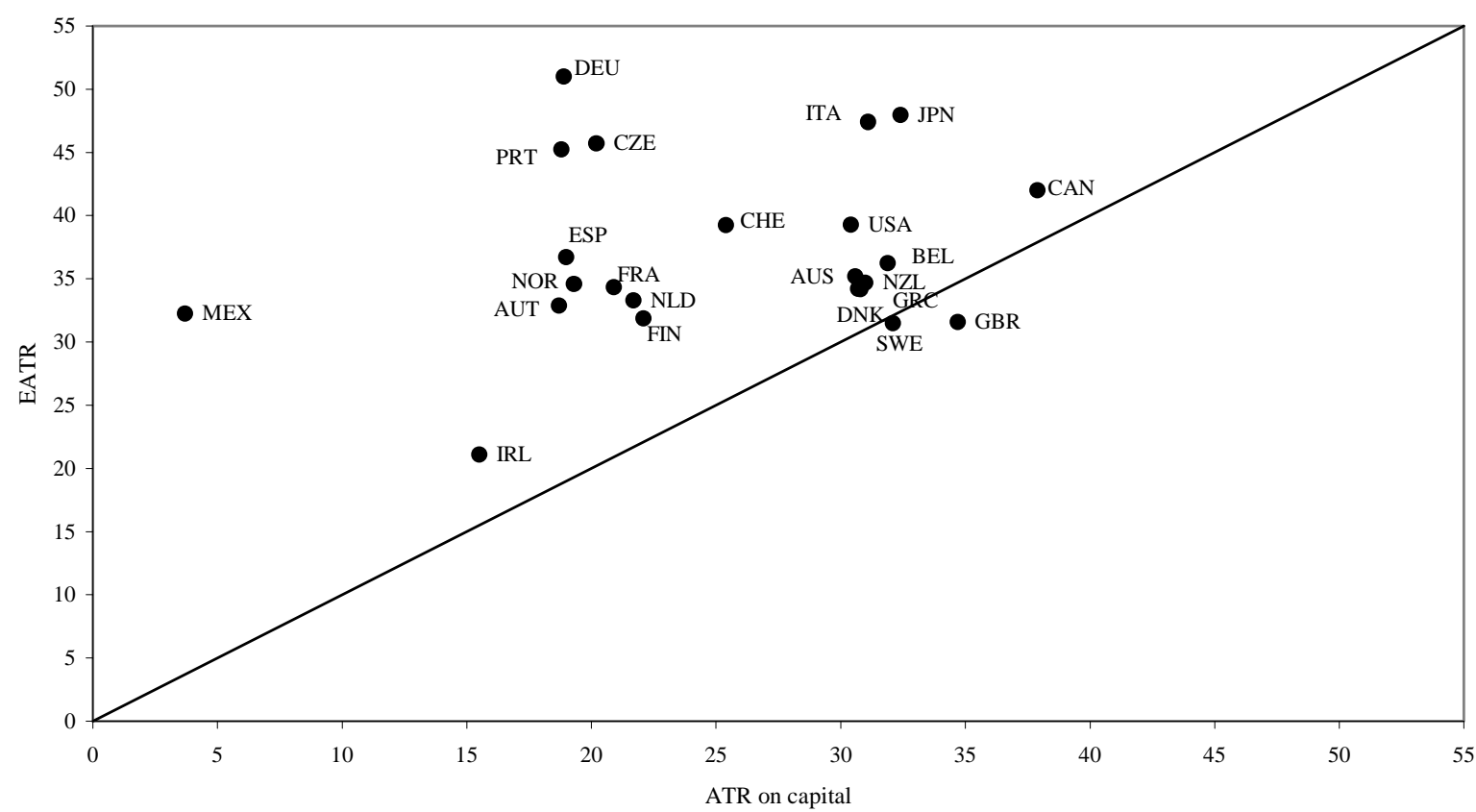

1. An effective average tax rate on inward FDI refers to the rate applied by a host country to the average investor country's infra-marginal investment that earns some economic rent i.e. a project that earns more than the minimum required after-tax rate of return. Average tax rates (ATR) on capital relates realised tax revenues directly to net operating surplus, using the National Accounts and OECD Revenue Statistics.

Source: Carey and Tchilinguirian (2000) and OECD 


\section{Appendix 1: The methodology of calculating the EMTR and EATR on FDI}

20. This appendix summarises the methodology developed by Devereux and Griffith (1999) and used in this paper to calculate the effective marginal and average tax rates on foreign direct investment (FDI).

\section{A1. Foreign direct investment in the absence of taxation}

21. The approach assumes that a subsidiary is wholly-owned and fully-financed by a parent firm. Suppose that the subsidiary finances an investment project by reducing its dividends to the parent by one unit. The parent in turn reduces its dividend payment to the shareholders by one unit. In period $t+1$, the value of its new investment is equal to $(1-\delta)\left(1+\pi_{n}\right)$, where $\delta$ and $\pi_{n}$ represent the depreciation rate of assets and the inflation rate in the host country $(n)$, respectively. At the same time, the investment made in period $t$ generates a return of $(p+\delta)\left(1+\pi_{n}\right)$ in period $t+1$ where $p$ is defined as the pre-tax real rate of return on investment. Thus the subsidiary pays a dividend of $E(1+p)\left(1+\pi_{n}\right)$ to a parent where $E$ denotes the bilateral exchange rate. In the absence of tax, the net present value of one unit of investment to the shareholders $\left(R^{*}\right)$, therefore, can be written as follows:

$$
R^{*}=-1+\frac{E(1+p)\left(1+\pi_{n}\right)}{1+i}
$$

where $(1+i)=(1+r)(1+\pi)$ where $\pi$ is the inflation rate in the home country, and $r$ denotes a real interest rate on alternative investment. Assuming the purchasing power parity (PPP) holds, i.e $E=(1+\pi) /\left(1+\pi_{n}\right), R^{*}$ simplifies to $(p-r) /(1+r)$.

22. Similarly, it can be shown that, in the presence of uniform inflation and real interest rate across trading countries, the pre-tax net present value of investment or pre-tax economic rent to shareholders is independent of the sources of finance and is the same as in the expression (1).

\section{A2. Introducing host country taxation on FDI}

23. Investment is usually entitled to depreciation allowances and therefore the net cost of investment to the subsidiary is reduced by $\tau_{n} \phi$ where $\tau_{n}$ and $\phi$ represent the statutory corporate tax rate of the host country and depreciation allowances for tax purposes, respectively. Following King and Fullerton (1984), and denoting by $\rho$ the shareholder's discount rate and by $N$ the number of years for which a depreciation allowance can be claimed, the net present value of depreciation allowances for one unit of investment in the host country can be written as: ${ }^{19}$

19. The value of cross-border investment to the shareholders in the home country is expressed in terms of home country currency and $E$ shows up in most of the calculations. Since it is assumed that $E$ in period $t$ is normalised to 1, and that PPP holds and that the inflation rate is uniform across countries, $E$ drops out from the formula. 
$A_{D B}=\frac{\tau_{n} \phi(1+\rho)}{\phi+\rho}$ for declining balance schedules, and

$A_{S L}=\frac{\tau_{n} \phi(1+\rho)}{\rho}\left(1-\frac{1}{(1+\rho)^{N}}\right)$ for straight line schedules.

24. If, after $M$ years, a switch from the declining balance system to the straight line system for a further $N$ years is made, the net present value of depreciation allowances is:

$$
A_{B}=A_{D B}\left[1-\frac{(1-\phi)^{M}}{(1+\rho)^{M}}\right]+A_{S L}\left(\frac{1}{(1+\rho)^{M}}\right)
$$

25. The net present value of depreciation allowances differs across the type of assets purchased. Abstracting from personal income tax implies that the shareholder's discount rate $(\rho)$ is equal to the nominal interest rate $(i)$.

\section{A3. Introducing international taxation}

26. FDI is subject to an additional layer of taxation associated with the cross-border payment of dividends and interest income repatriated by the subsidiary in the host country to the parent in the home country $(j)$.

27. The total tax due on the repatriation of one unit of dividends from the subsidiary to the parent is defined by $\sigma$. This may include a host-country withholding tax levied on dividends $\left(c_{n}\right)$ plus any additional tax imposed by the home country. The existence of the additional home country tax depends on the home country's tax treatment of foreign-source dividend: exemption, credit with limitation or deduction. That is:

$$
\begin{aligned}
\sigma & =c_{n} & & \text { exemption } \\
& =\max \left\{\frac{\tau_{j}-\tau_{n}}{1-\tau_{n}}, c_{n}\right\} & & \text { credit with limitation } \\
& =\tau_{j}\left(1-c_{n}\right)+c_{n} & & \text { deduction }
\end{aligned}
$$

28. Similarly, the total tax due on interest payments from the subsidiary to the parent is defined by $\omega$. This may include a host-country withholding tax levied on interest income $\left(\overline{\omega_{n}}\right)$ plus any additional tax imposed by the home country. Since interest payments are deductible from taxable income as operating expenses, the overall host-country tax due on debt-financed investment tends to be smaller than that on equity-financed investment. The existence of the additional home country tax again depends on the home country's tax treatment of foreign-source interest: exemption, credit with limitation or deduction. That is:

$\omega=\bar{\omega}_{n}-\tau_{n} \quad$ exemption 


$$
\begin{array}{ll}
=\max \left\{\tau_{j}, \overline{\omega_{n}}\right\}-\tau_{n} & \text { credit with limitation } \\
=\tau_{j}\left(1-\overline{\omega_{n}}\right)+\overline{\omega_{n}}-\tau_{n} & \text { deduction }
\end{array}
$$

\section{A4. Foreign direct investment in face of the home and host country taxation}

29. The economic rent generated from one unit of cross-border investment given the home and host country taxation can be derived as follows. The economic rent or net present value of one unit of investment $(R)$ can be split into three parts: $(i)$ the rent attributable to the investment in the subsidiary financed by retained earnings ( $R_{n}^{R E}$ ); (ii) the additional cost of the parent raising external finance $\left(F_{j}\right)$ or the rent associated with new equity or debt financing of the parent firm; (iii) the additional cost of the subsidiary raising finance from the parent $\left(F_{n}\right)$ or the rent associated with new equity or debt financing of the subsidiary from the parent. Thus the economic rent earned from one unit of investment by the subsidiary is given by $R_{n}=R_{n}^{R E}+F_{j}+F_{n}$. The following explains each part of economic rents according to the financing sources.

\section{A4.1. Finance by retained earning of subsidiary and parent $\left(R_{n}^{R E}\right)$}

30. Consider the case in which the subsidiary finances its investment by retained earnings and the parent finances its reduced dividend income by reducing dividends paid to the shareholders. Since the tax rate on the cross-border payment on dividend is $\sigma$ and the net present value of allowances is $\left(1-A_{n}\right)$, the net cost of investment to the shareholder in period $t$ is given by $\gamma_{j}(1-\sigma)\left(1-A_{n}\right)$ where $\gamma_{j}$ denotes the tax discrimination factor between new equity and retained earning. Abstracting from personal income tax implies that the tax discrimination factor $\left(\gamma_{j}\right)$ is equal to unity. The net return from one unit of investment is given by $\left(1-\tau_{n}\right)(p+\delta)\left(1+\pi_{n}\right)$, and the value of investment in period $t+1$ remains $\left(1-A_{n}\right)(1-\delta)\left(1+\pi_{n}\right)$. Both of these should then be adjusted for the exchange rate and the tax due on repatriated dividends to the parent. Where the exchange rate in period $t$ is normalised to 1 , and PPP holds, and the inflation rate is uniform across countries, the net present value of one unit of investment to the parent company can be written as:

$$
\begin{aligned}
& R_{n}^{R E}=\gamma_{j}(1-\sigma)\left\{-\left(1-A_{n}\right)+\frac{\left(1-\tau_{n}\right)(p+\delta)\left(1+\pi_{n}\right)+\left(1-A_{n}\right)(1-\delta)\left(1+\pi_{n}\right)}{1+\rho}\right\} \\
& =\gamma_{j}(1-\sigma)\left\{\frac{\left(1-\tau_{n}\right)(p+\delta)\left(1+\pi_{n}\right)-\left(1-A_{n}\right)\left[(1+\rho)-(1-\delta)\left(1+\pi_{n}\right)\right]}{1+\rho}\right\}
\end{aligned}
$$

31. While the depreciation allowances $\left(A_{n}\right)$ are adequately taken into account for machinery and buildings, $R_{n}^{R E}$ should be modified in the case of investment in inventories in order to reflect the situation that any increase in the value of inventories due to inflation is taxed under FIFO method. Thus an 
additional term is added for investment in inventories when inventories are valued by FIFO method $(2 a)$. This is in compliance with OECD (1991) and EC (2001).

$$
R_{I N V}^{R E}=R_{n}^{R E}-\frac{\gamma_{j}(1-\sigma)}{(1+\rho)} \times \frac{\tau_{n} \pi_{n}}{\left(1-\tau_{n}\right)\left(1+\pi_{n}\right)}
$$

\section{A4.2. Finance by the parent $\left(F_{j}\right)$}

32. In the case of equity finance by the parent, the net cost or the amount of new equity raised for one unit of investment is $\left(1-\tau_{n} \phi_{n}\right)$ in period $t$. Compared to the case of retained earnings, the shareholders contribute $\left(1-\tau_{n} \phi_{n}\right)$ in new equity, but instead receive a net income of $\gamma_{j}\left(1-\tau_{n} \phi_{n}\right)$ through higher dividends. In period $t+1$, the shareholders receive $\left(1-\tau_{n} \phi_{n}\right)$ as a repurchase of equity. Compared to the case of retained earnings, this implies that dividends paid in period $t+1$ are lower by this amount and that the shareholders receive lower net income of $\gamma_{j}\left(1-\tau_{n} \phi_{n}\right)$ through lower dividends. In the case of debt finance by the parent, the shareholders do not have to give up dividends in period $t$. However, the parent should repay $\left(1-\tau_{n} \phi_{n}\right)(1+i)$ in period $t+1$. Since interests paid by the parent are deductible from the home country taxation, the debt finance reduces the net income to the shareholders by $\gamma\left(1-\tau_{n} \phi_{n}\right)\left(1+i\left(1-\tau_{j}\right)\right)$, in comparison to the case of retained earnings. Thus after rearranging terms, the additional rent associated with the parent's finance $\left(F_{j}\right)$, compared to the case of retained earnings, can be written as:

$$
\begin{aligned}
F_{j} & =0 & & \text { if the parent finances by retained earn } \\
& =\frac{-\rho\left(1-\gamma_{j}\right)\left(1-\tau_{n} \phi_{n}\right)}{1+\rho} & & \text { if the parent finances by new equity } \\
& =\frac{\gamma_{j}\left(1-\tau_{n} \phi_{n}\right)\left(\rho-i\left(1-\tau_{j}\right)\right)}{1+\rho} & & \text { if the parent finances by debt }
\end{aligned}
$$

\section{A4.3. Finance by the subsidiary $\left(F_{n}\right)$}

33. In the case in which the subsidiary issues new equity to the parent in period $t$, the difference between the net cost to the parent in this case, $\left(1-\tau_{n} \phi_{n}\right)$, and the net cost in the case of retained earnings, $(1-\sigma)\left(1-\tau_{n} \phi_{n}\right)$, represents the additional cost associated with equity finance by the subsidiary at a cost of $\gamma_{j} \sigma\left(1-\tau_{n} \phi_{n}\right)$ to the shareholders. Therefore, the additional rent associated with new equity by the subsidiary can be summarised after rearranging the terms as:

$$
F_{n}=0
$$

if the subsidiary finances by retained earning 


$$
=\gamma_{j} \sigma\left(1-\tau_{n} \phi_{n}\right)\left\{\frac{-\rho}{1+\rho}\right\}
$$

if the subsidiary finances by new equity

The economic rent in the case of debt finance by the subsidiary can be expressed in a similar fashion:

$F_{n}=\frac{\gamma_{j}\left(1-\tau_{n} \phi_{n}\right)}{(1+\rho)}\left\{\sigma\left[\left(1+i\left(1-\tau_{n}\right)-(1+\rho)\right]-\omega i\right\}\right.$ if the subsidiary finances by debt

\section{A5. The effective marginal tax rates (EMTR) on FDI}

34. The EMTR applies to marginal investment with zero post-tax economic rent or profit $\left(R_{n}=0\right)$. Thus the calculation of the EMTR requires the estimation of the cost of capital ( $\tilde{p})$. The cost of capital is defined as the pre-tax rate of return that is necessary to produce a zero post-tax economic rent or a predetermined post-tax rate of return on alternative investment. This is achieved by finding the value of $p$ for which $R_{n}=0$. It is straightforward to show that this value of $p$ is: ${ }^{20}$

$$
\tilde{p}=\frac{r \gamma_{j}(1+\sigma)\left(1-A_{n}\right)+\delta \gamma_{j}(1+\sigma)\left(\tau_{n}-A_{n}\right)-\left(F_{j}+F_{n}\right)(1+r)}{\gamma_{j}(1+\sigma)\left(1-\tau_{n}\right)}
$$

35. The EMTR is the percentage difference between the cost of capital $(\tilde{p})$ and the post-tax rate of return (i.e. the assumed post-tax rate of return on alternative investment in the absence of personal income and capital gains tax) as a proportion of the cost of capital. That is:

$$
\operatorname{EMTR}=\frac{\tilde{p}-r}{\tilde{p}} \times 100
$$

\section{A6. The effective average tax rate (EATR) on FDI}

36. The EATR applies to infra-marginal investment with positive post-tax economic rent or profit. It is measured as the difference between the pre-tax economic rent $\left(R^{*}\right)$ and the post-tax economic rent $\left(R_{n}\right)$ for a given level of the pre-tax rate of return. Fixing the pre-tax rate of return makes it possible to derive the corresponding pre-tax and post-tax economic rents. The denominator is carefully chosen to represent the net present value of the income stream in the absence of tax, $p /(1+r)$, because $R^{*}$, a natural candidate for the denominator, is not defined for investment projects whose pre-tax rents are zero in the absence of tax (i.e. $R^{*}=0$ ). That is to say:

20. Similarly the cost of capital for investment in inventories when inventories are valued by FIFO is adjusted such that $\tilde{p}_{i n v}=\tilde{p}+\tau_{n} \pi_{n} /\left[\left(1-\tau_{n}\right)\left(1+\pi_{n}\right)\right]$ 
ECO/WKP(2003)19

$$
E A T R=\frac{R_{j}^{*}-R_{j}}{p /(1+r)} \times 100
$$


ECO/WKP(2003)19

Appendix 2: 1991, 1996 and 2001 tax parameter data 


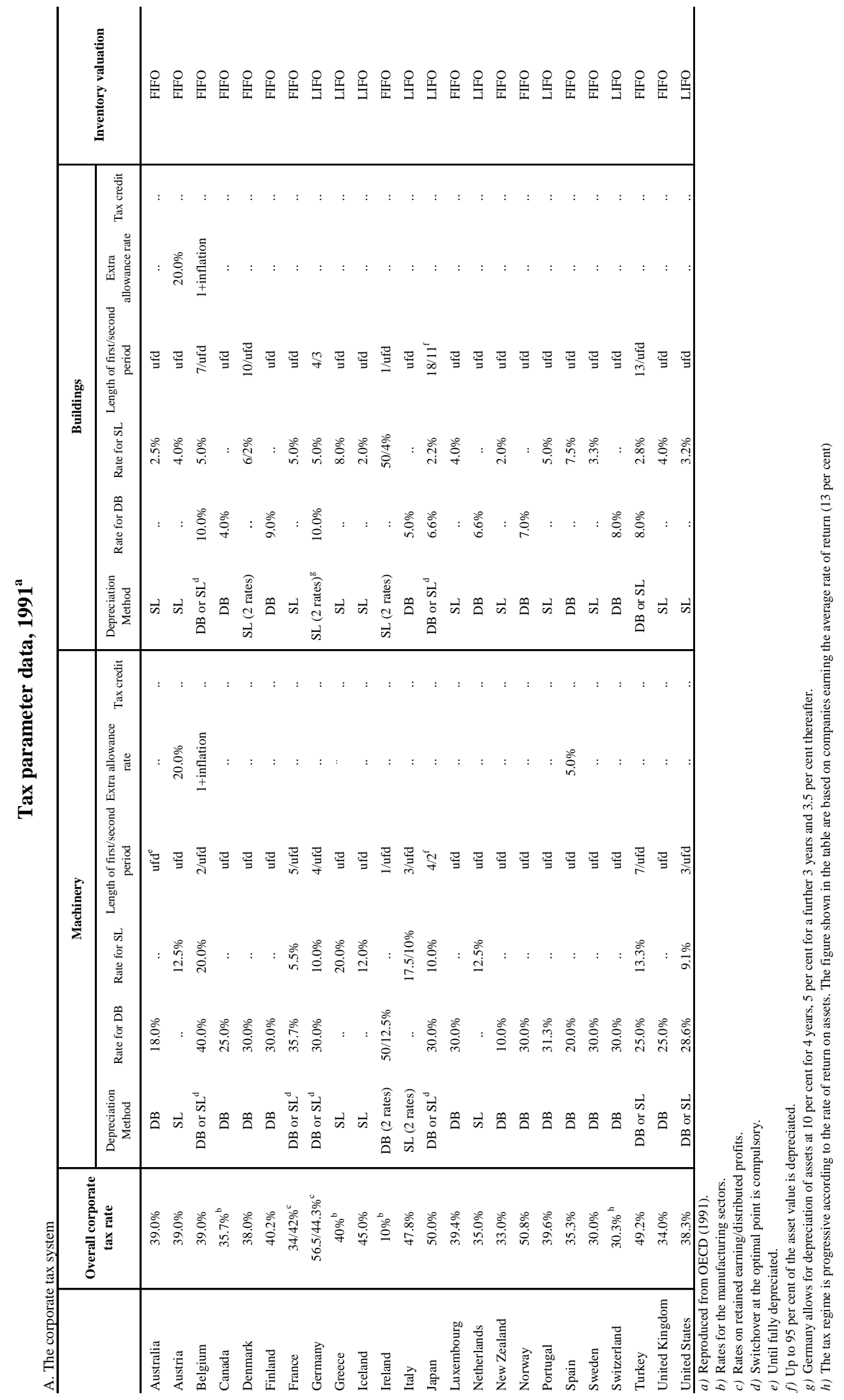




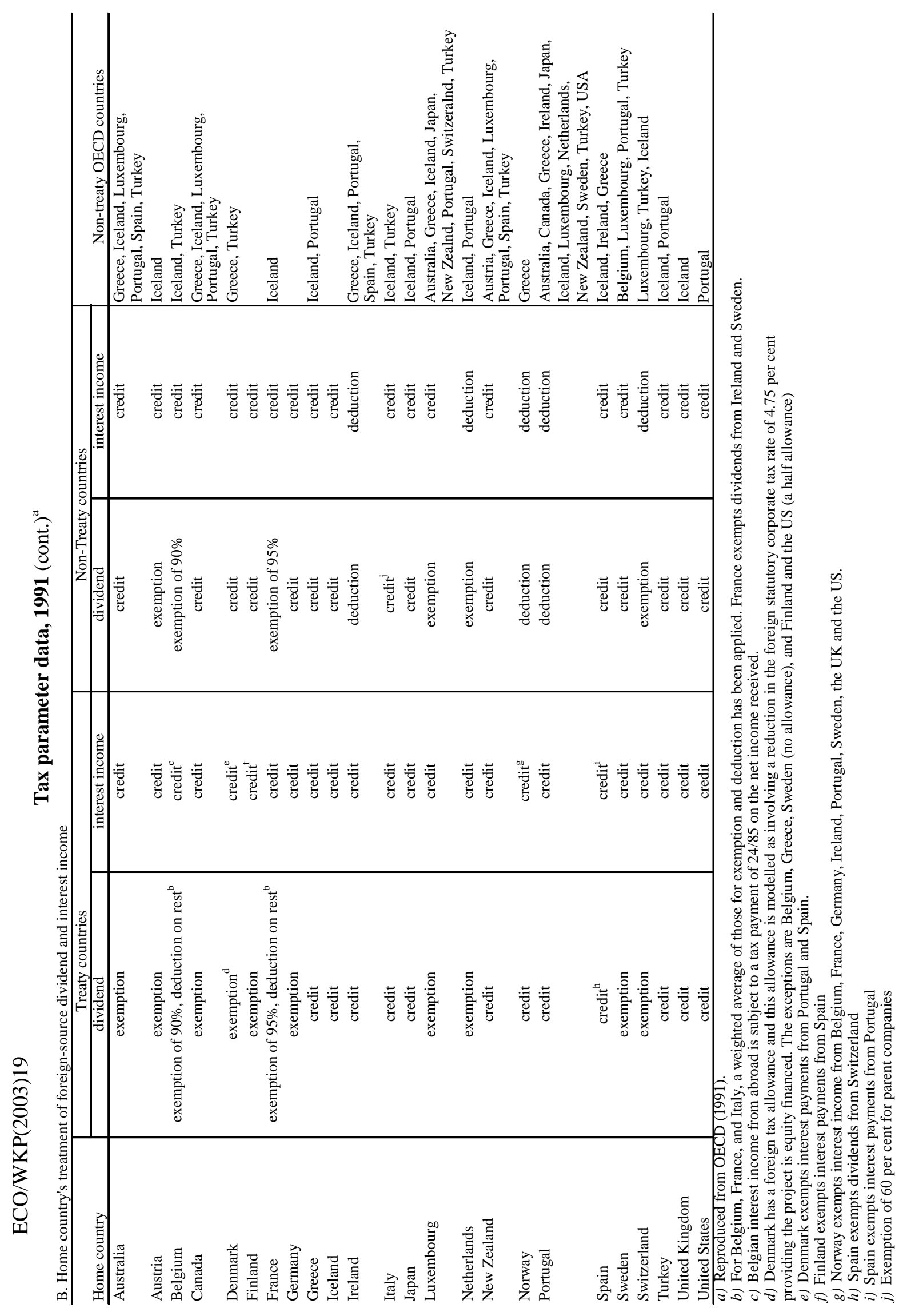




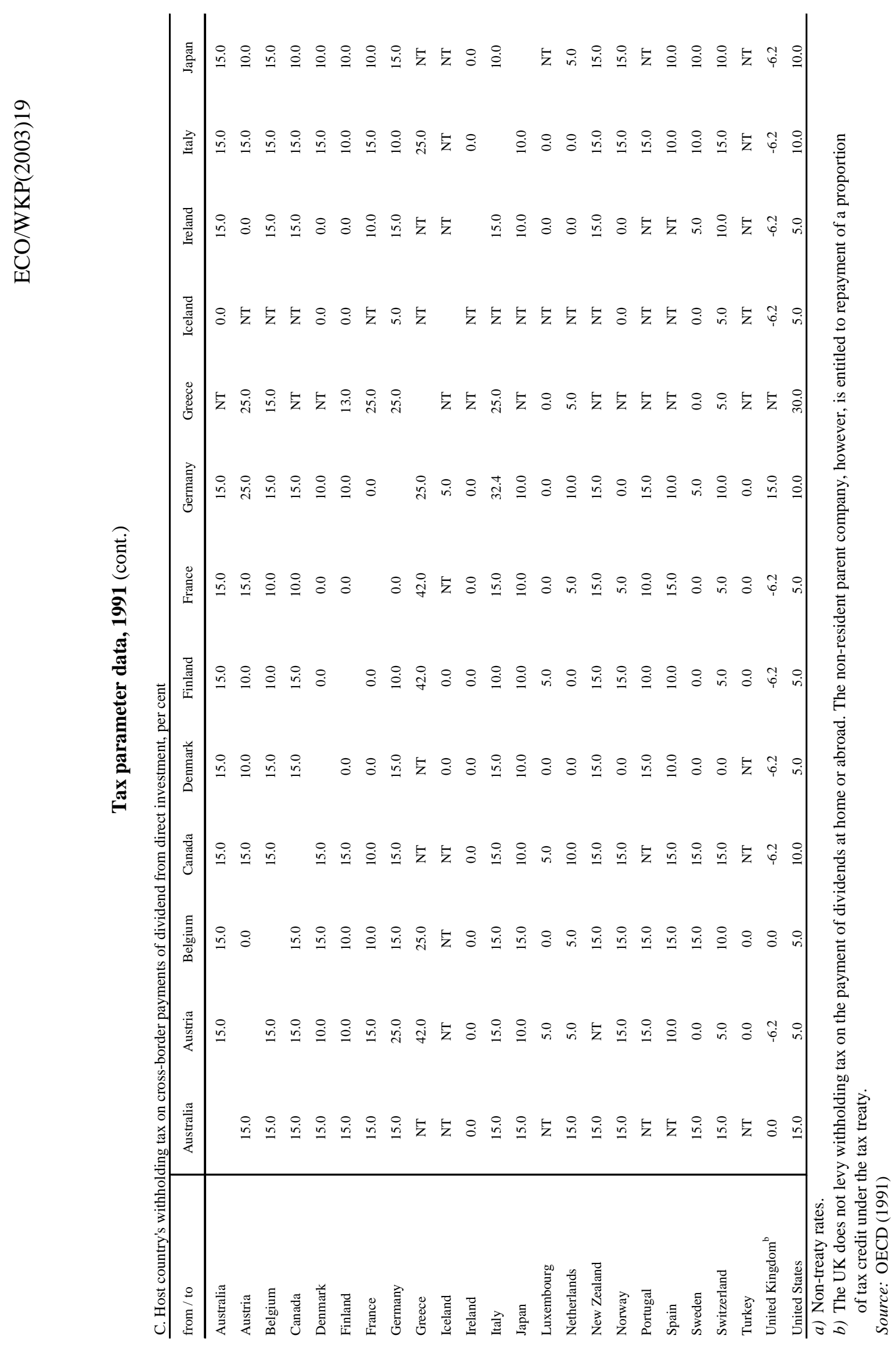




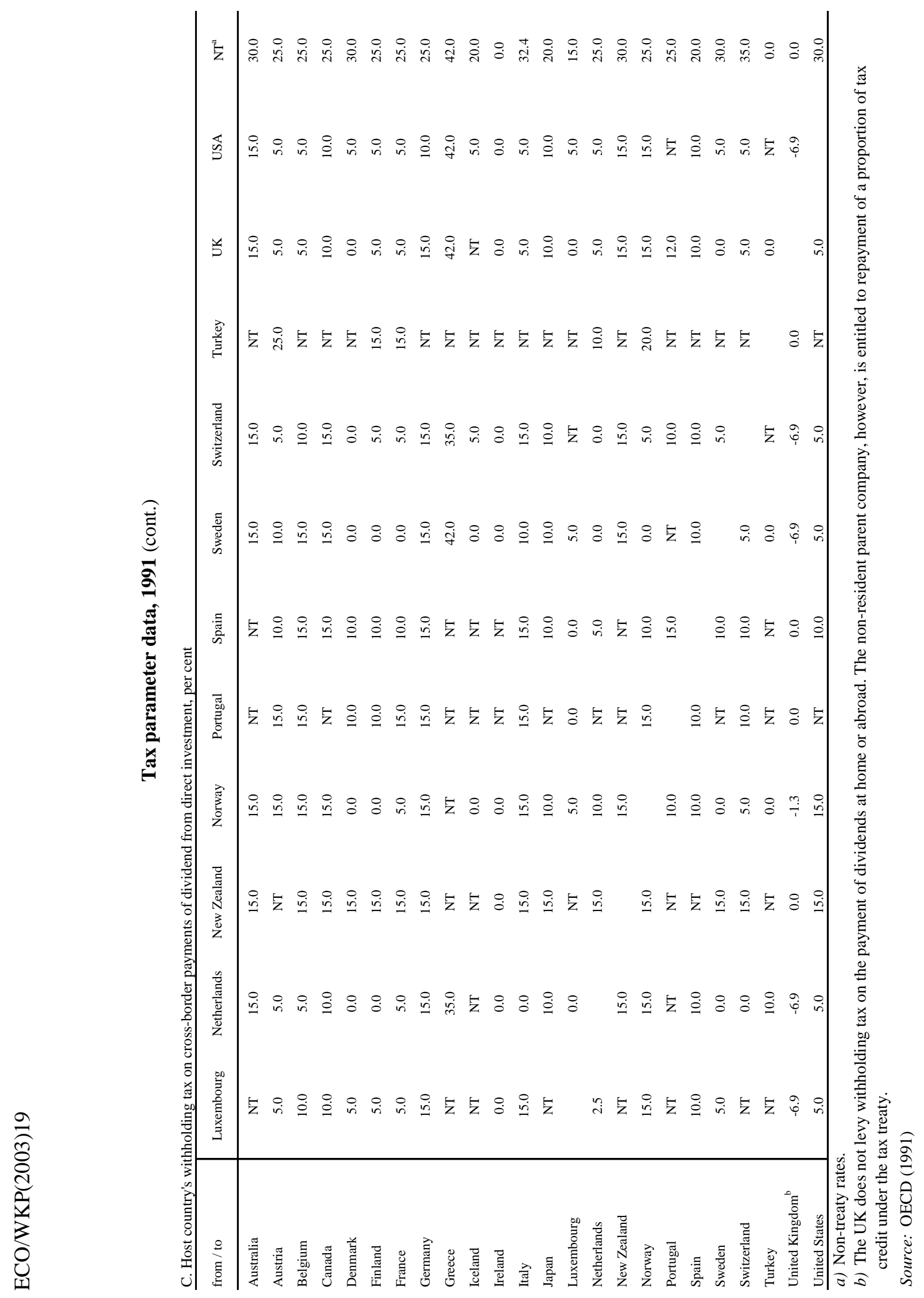




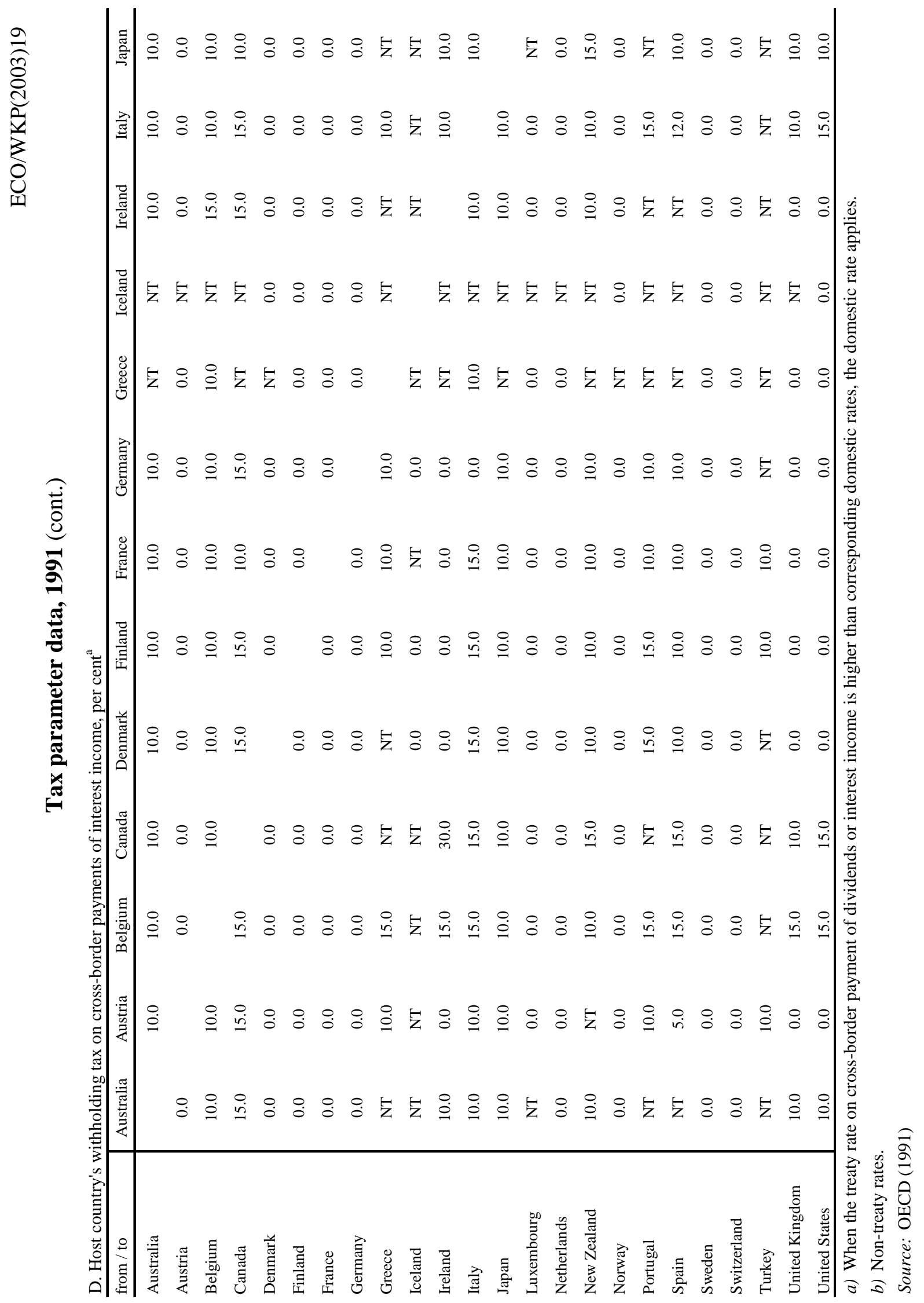




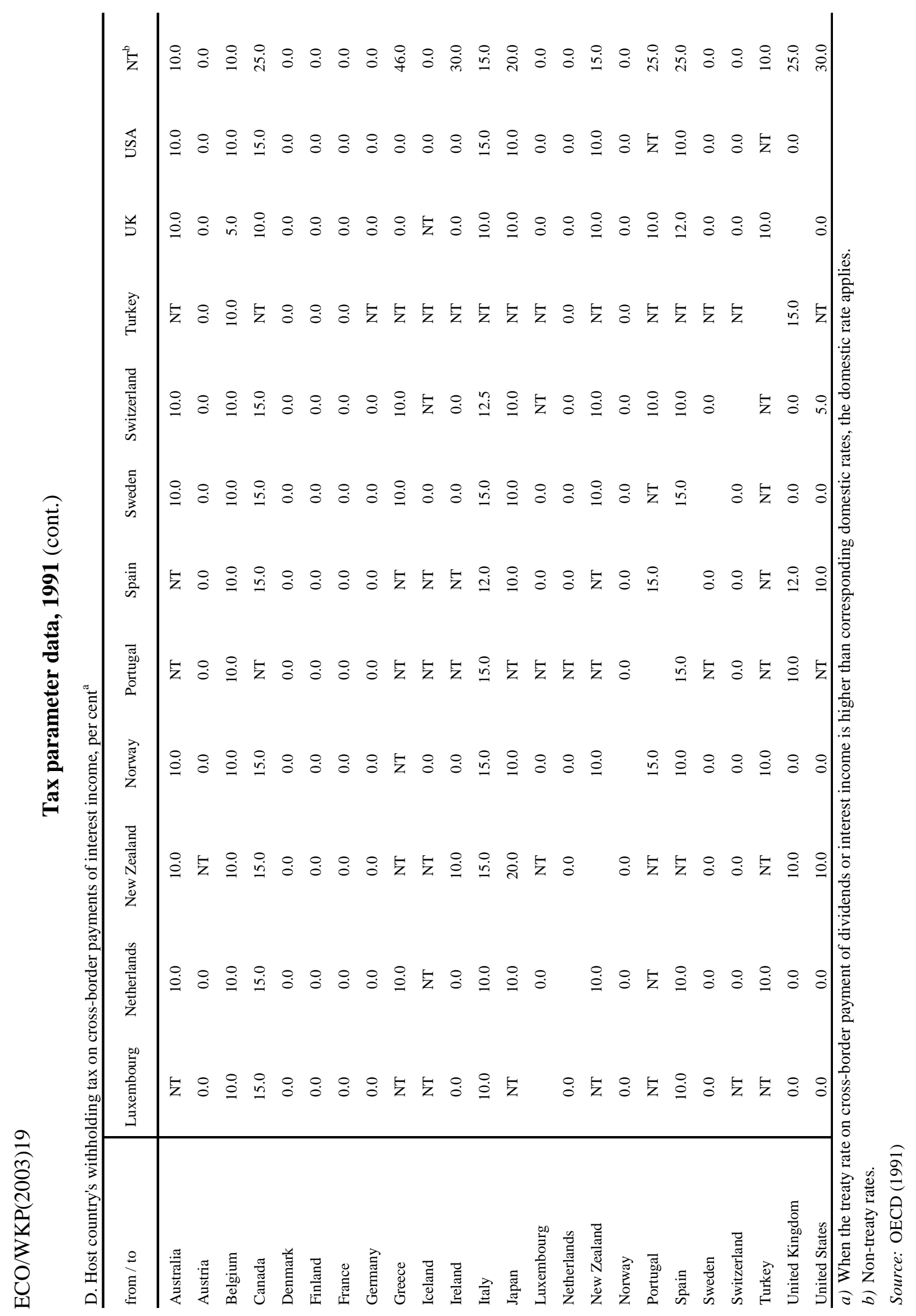




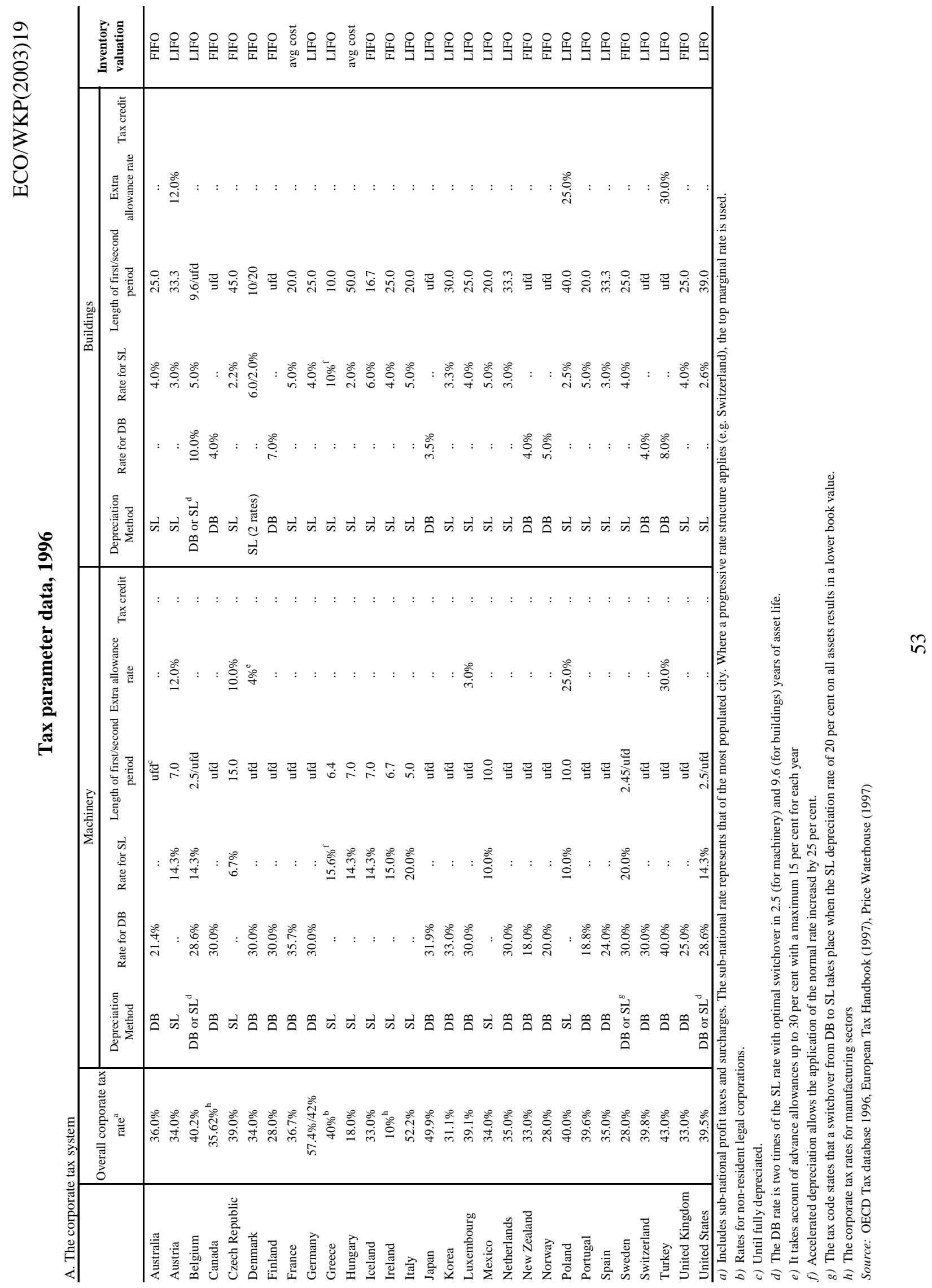




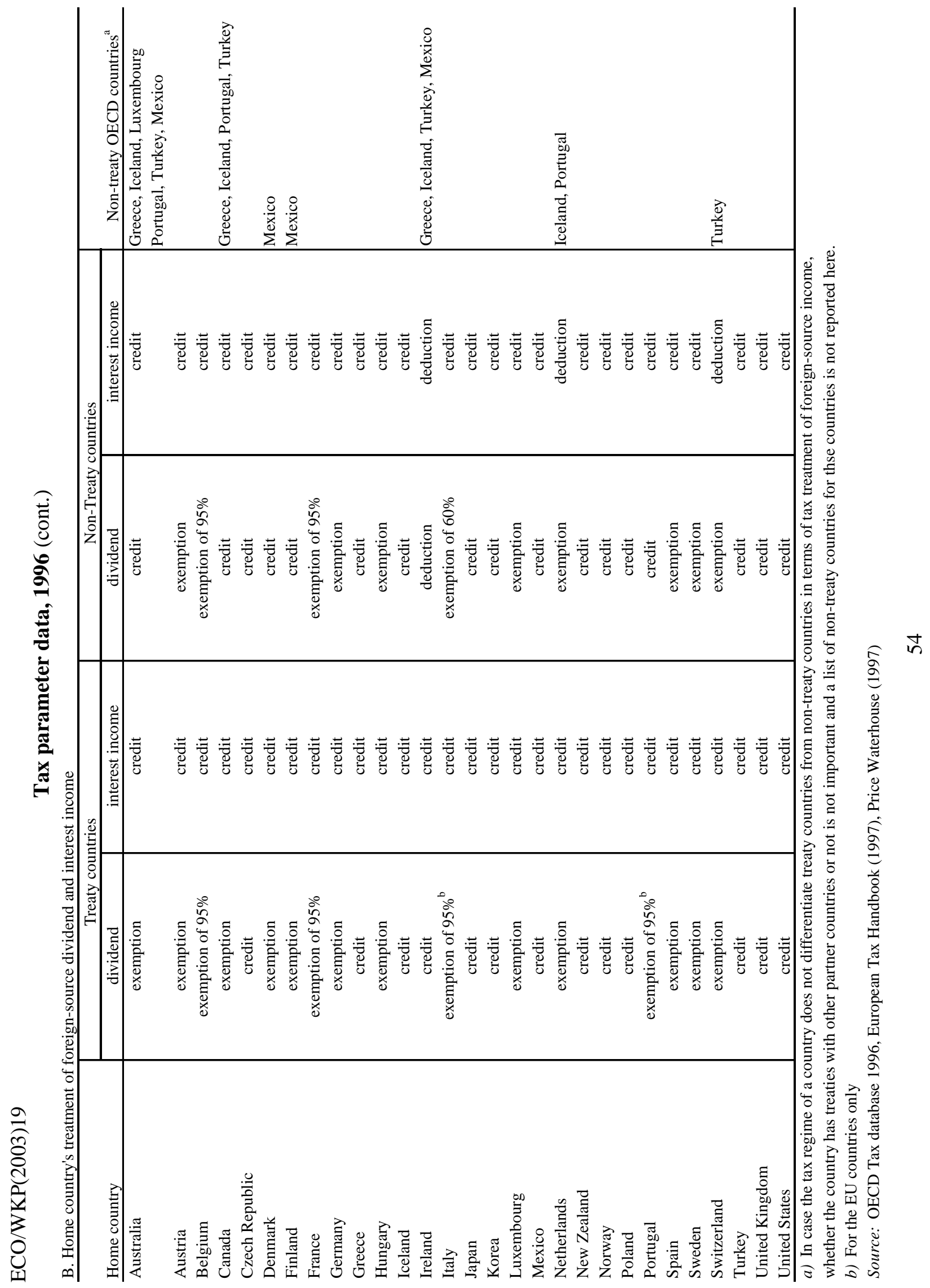




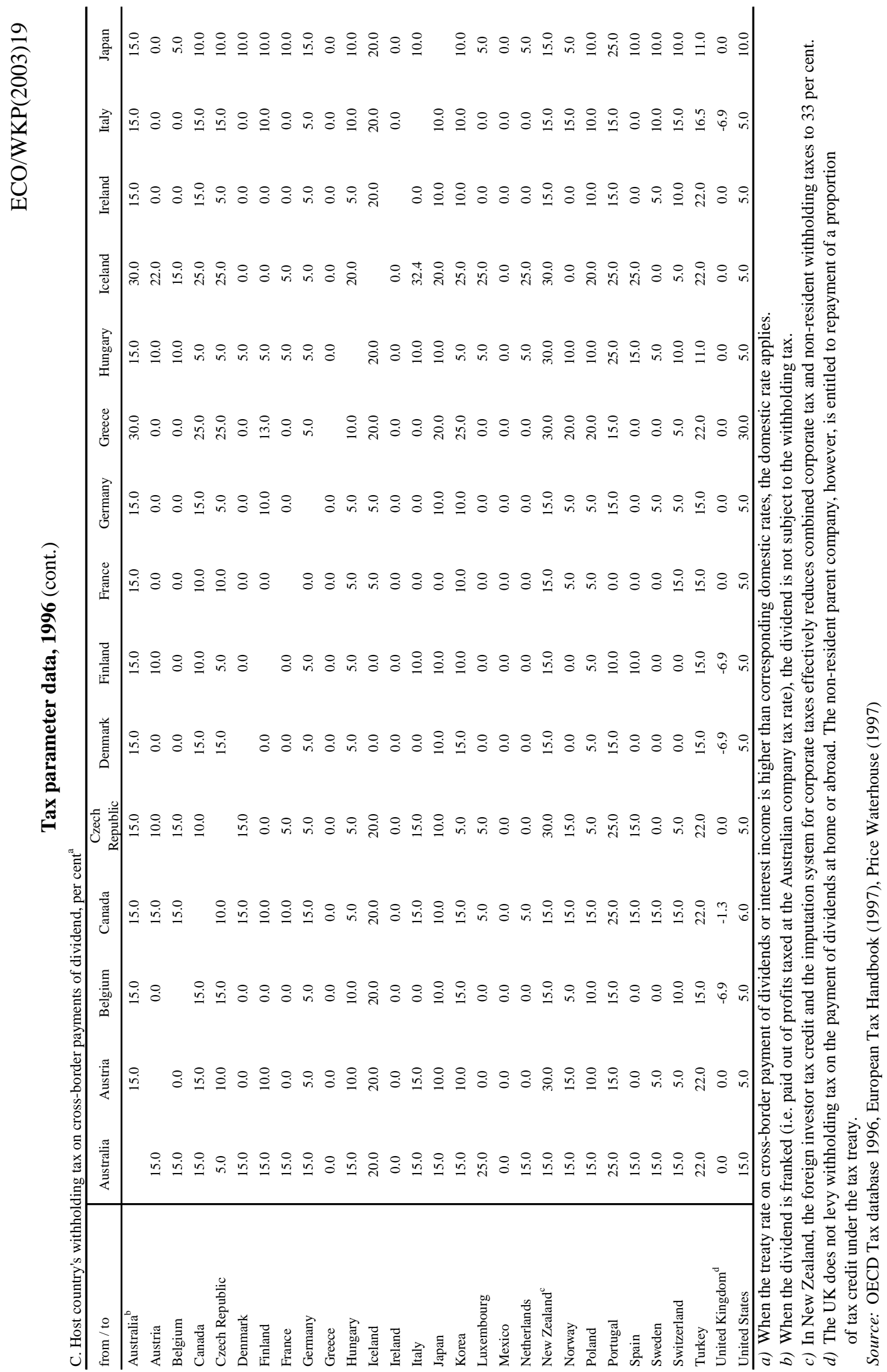




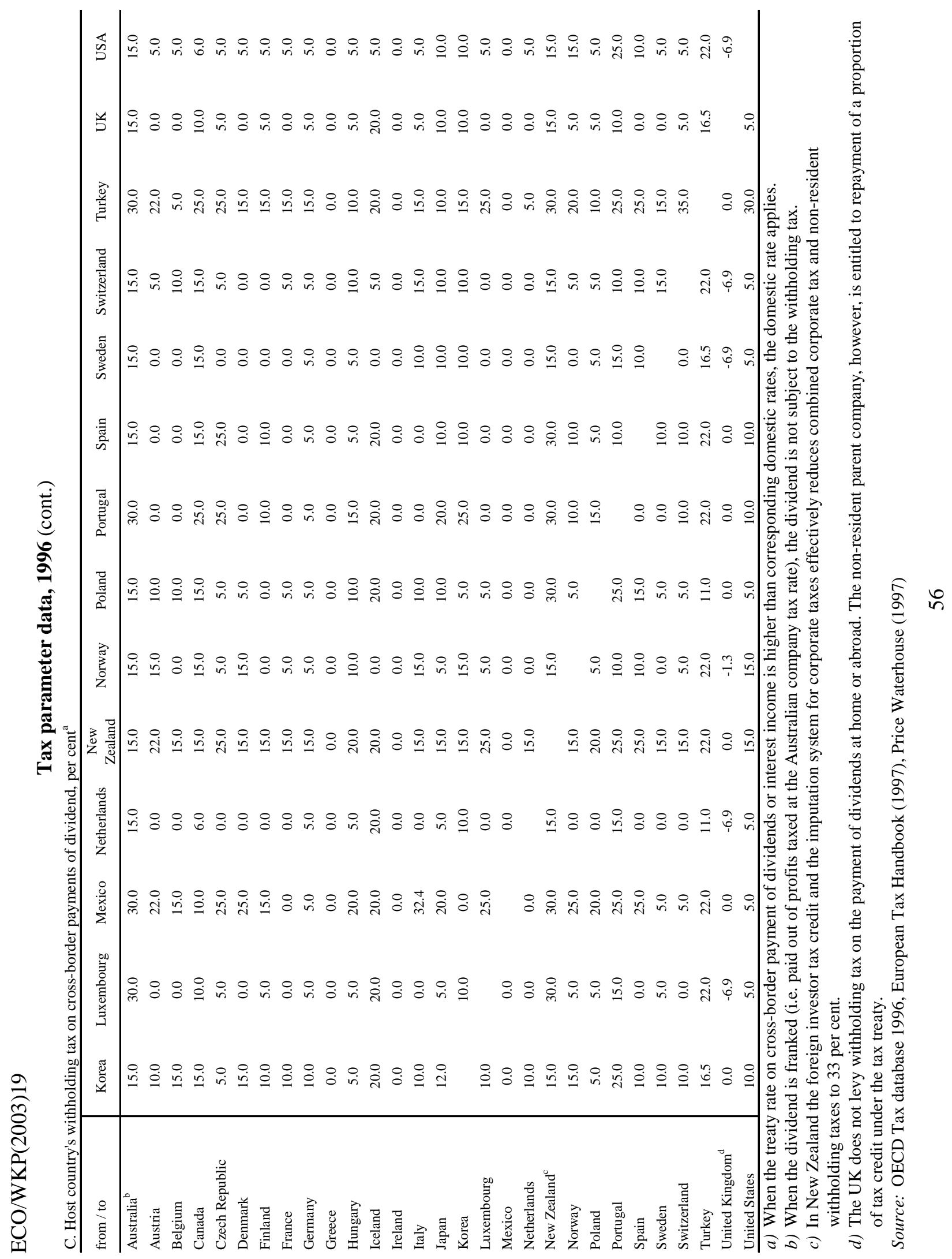




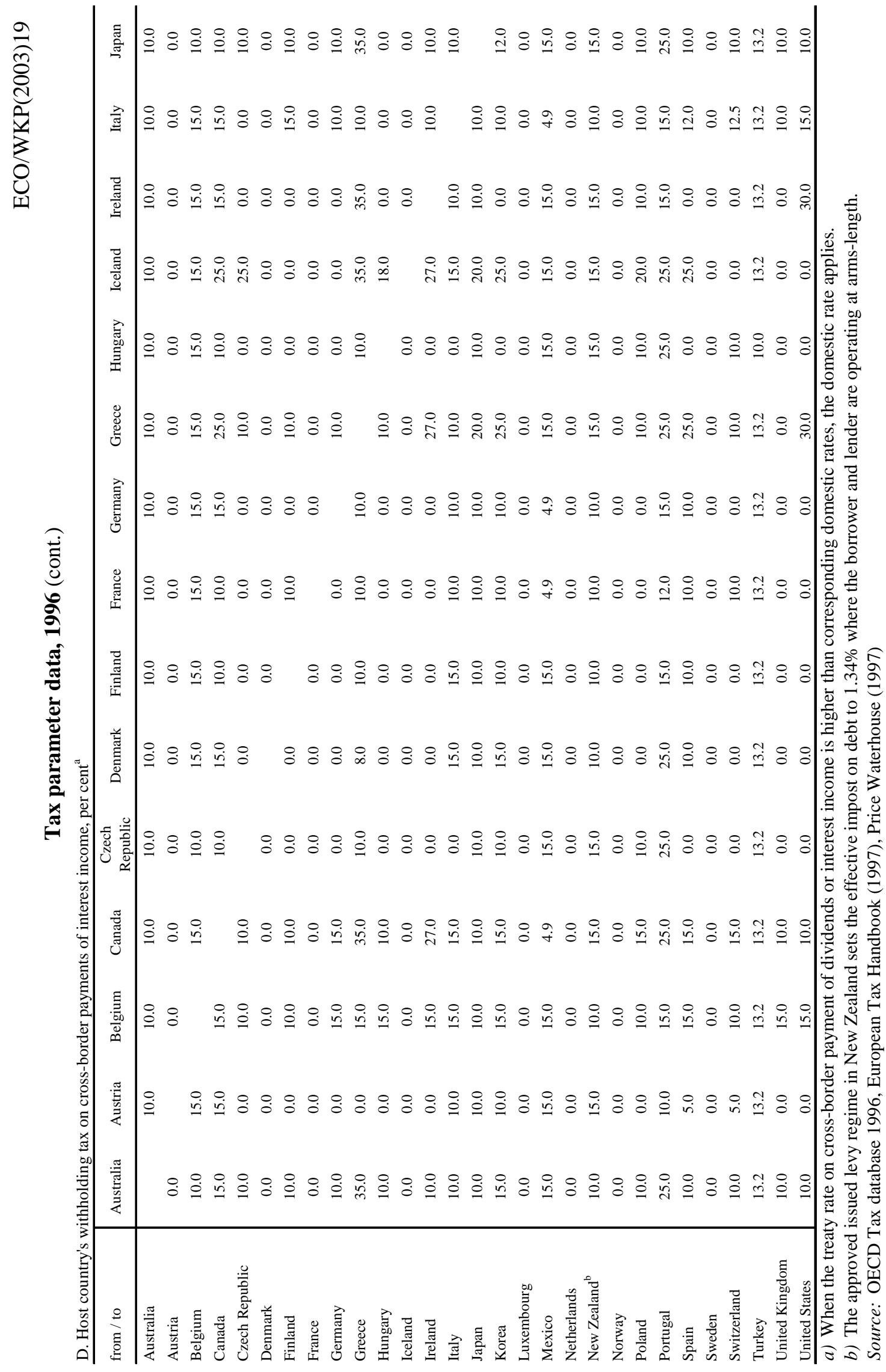

in 


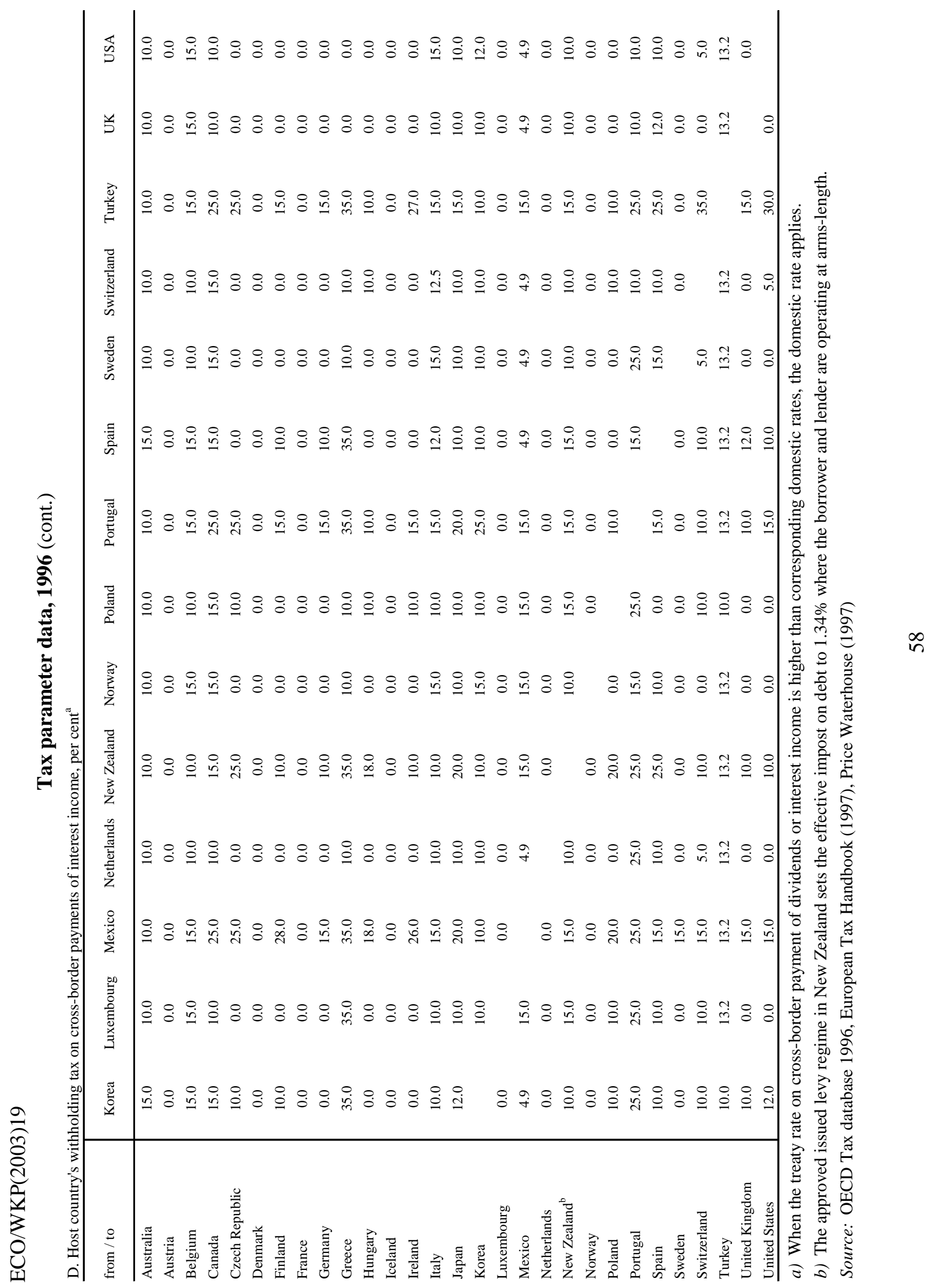


苍

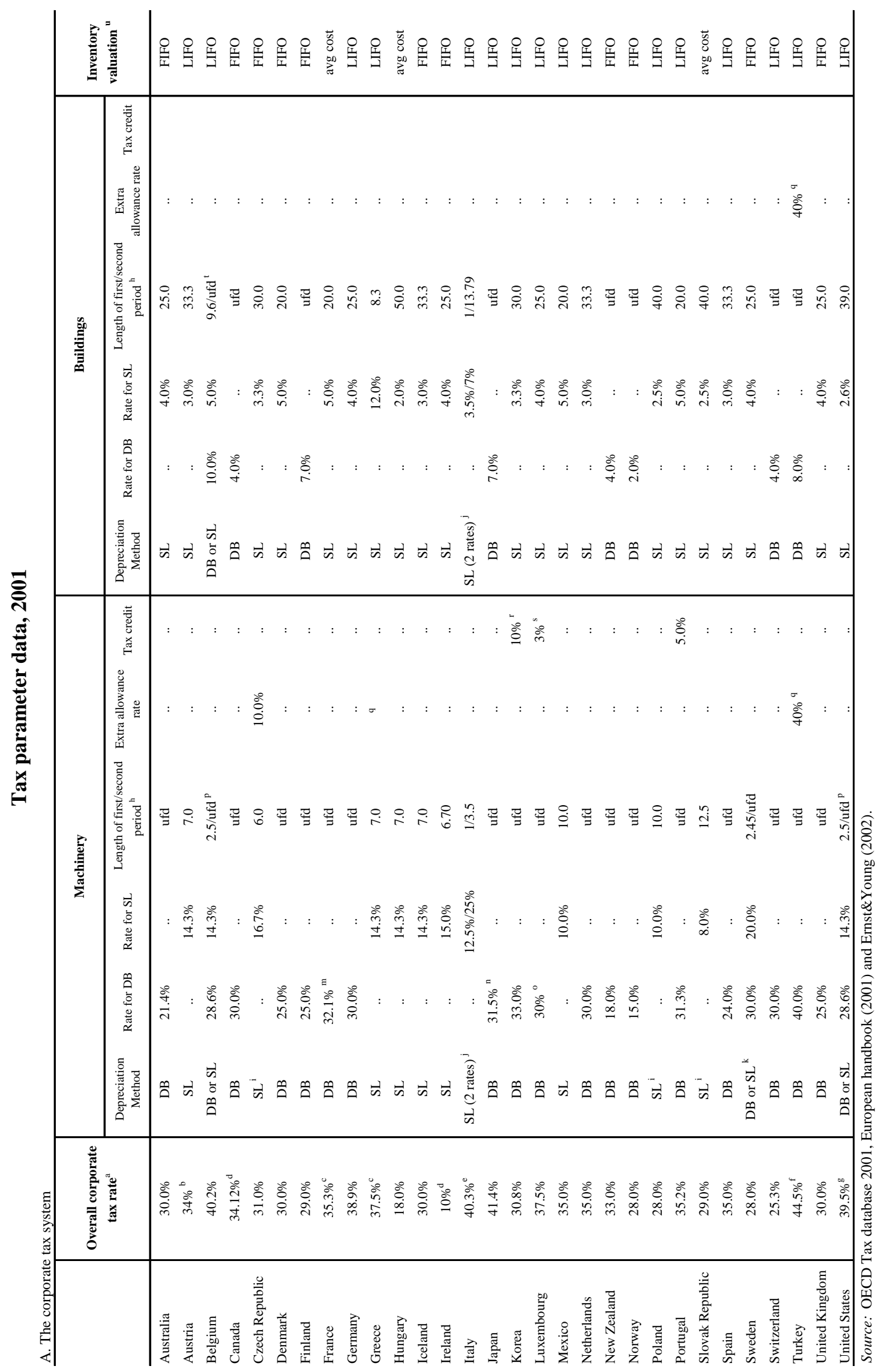

in 


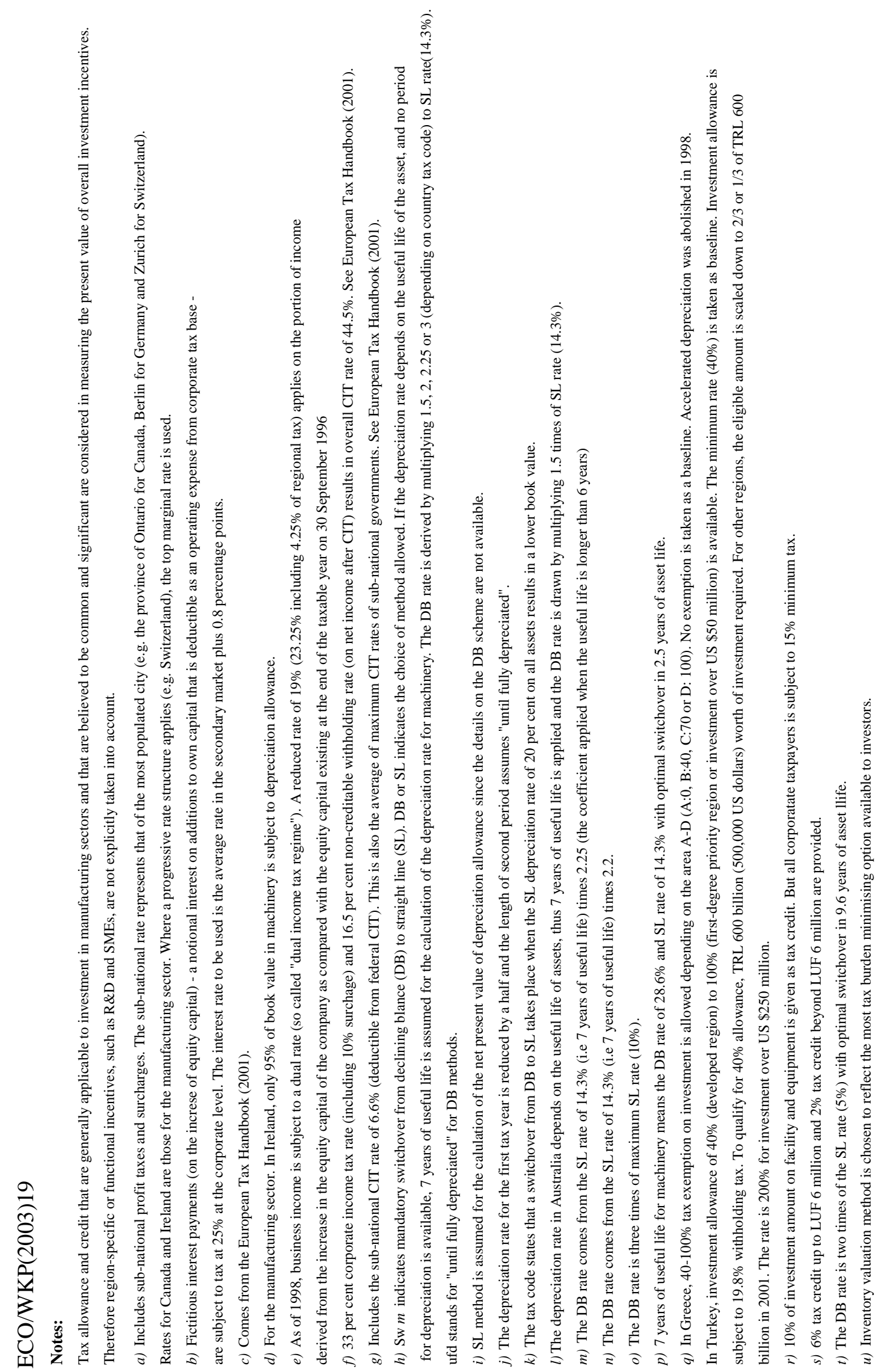




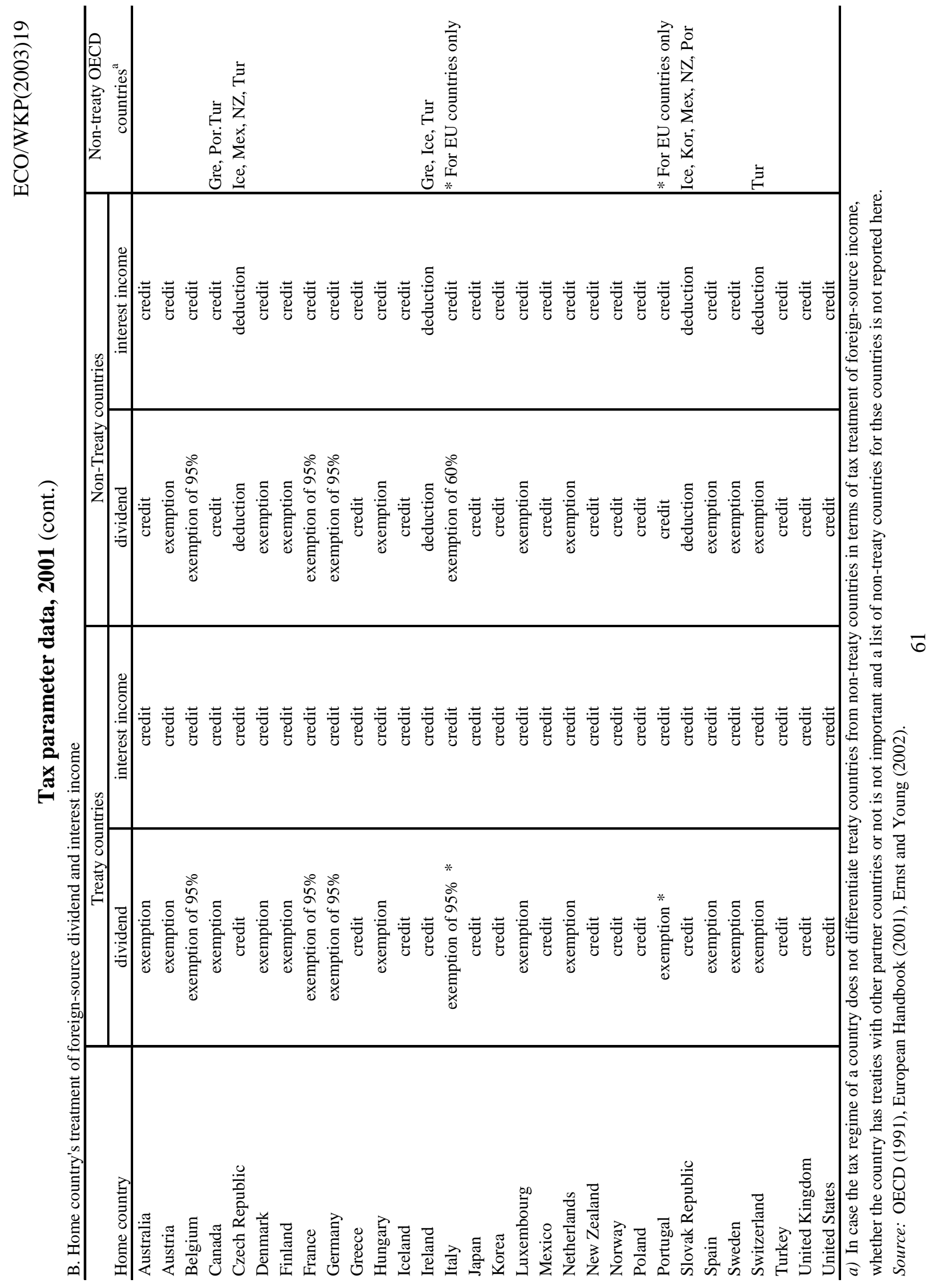




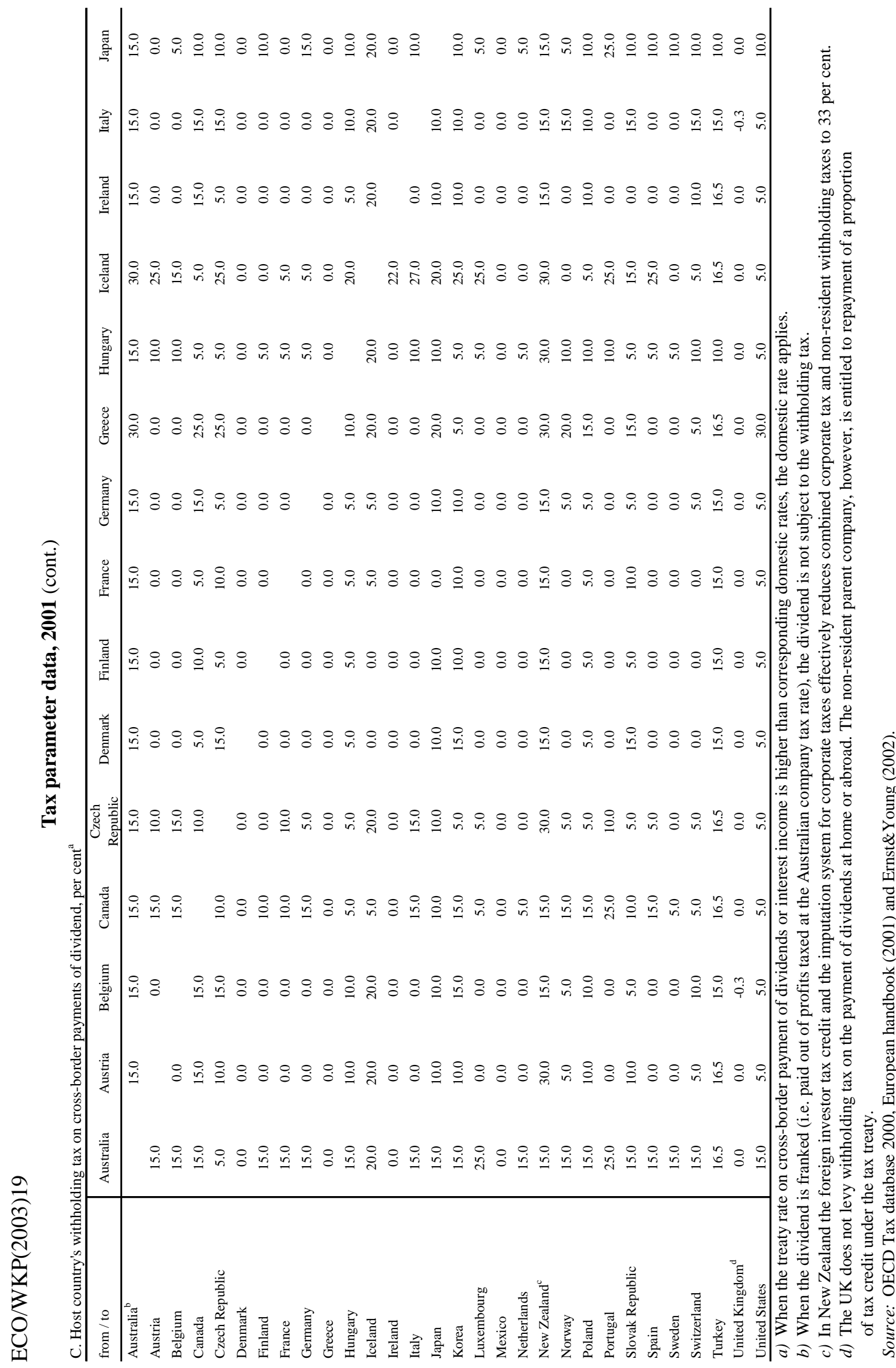




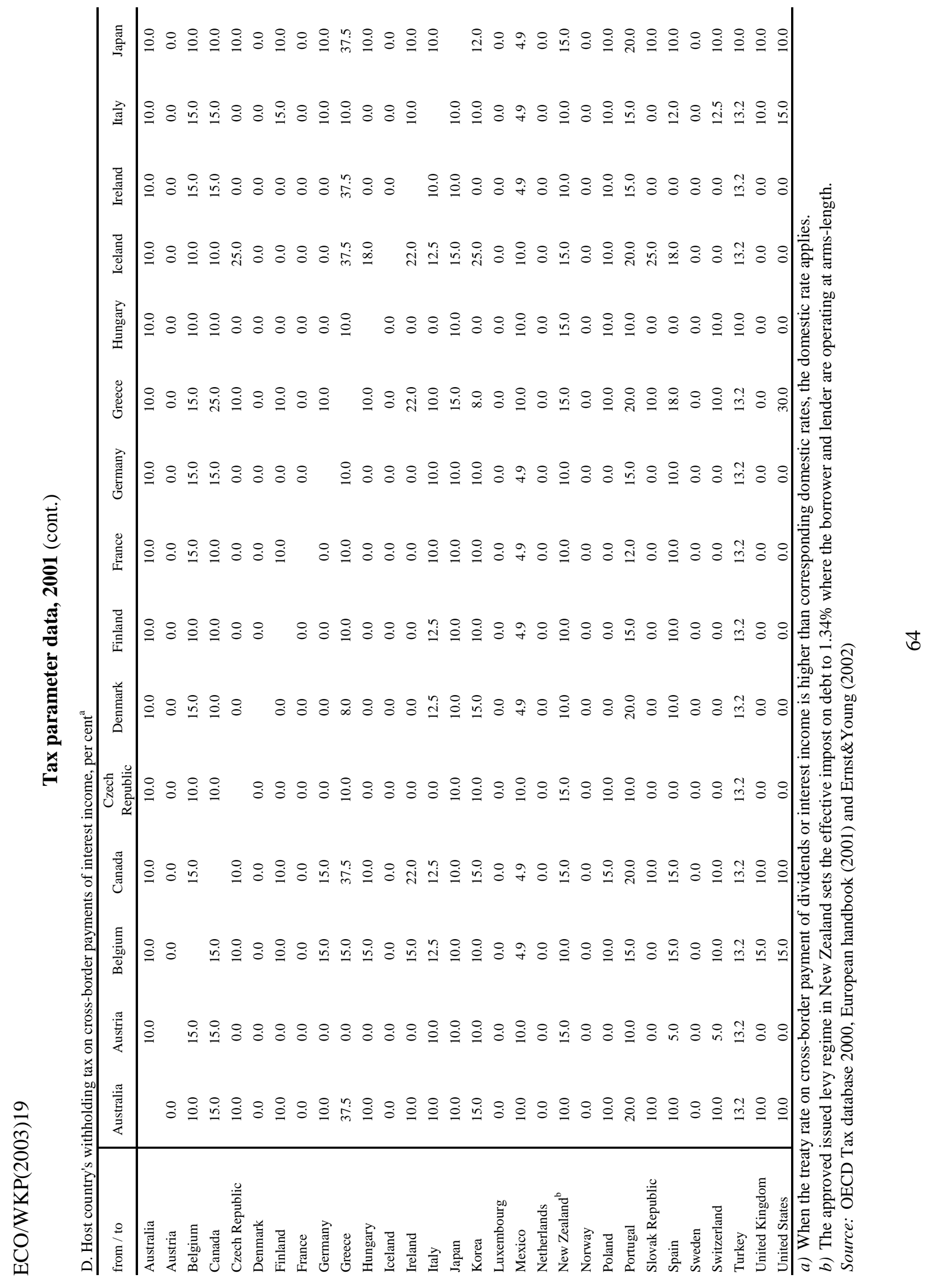




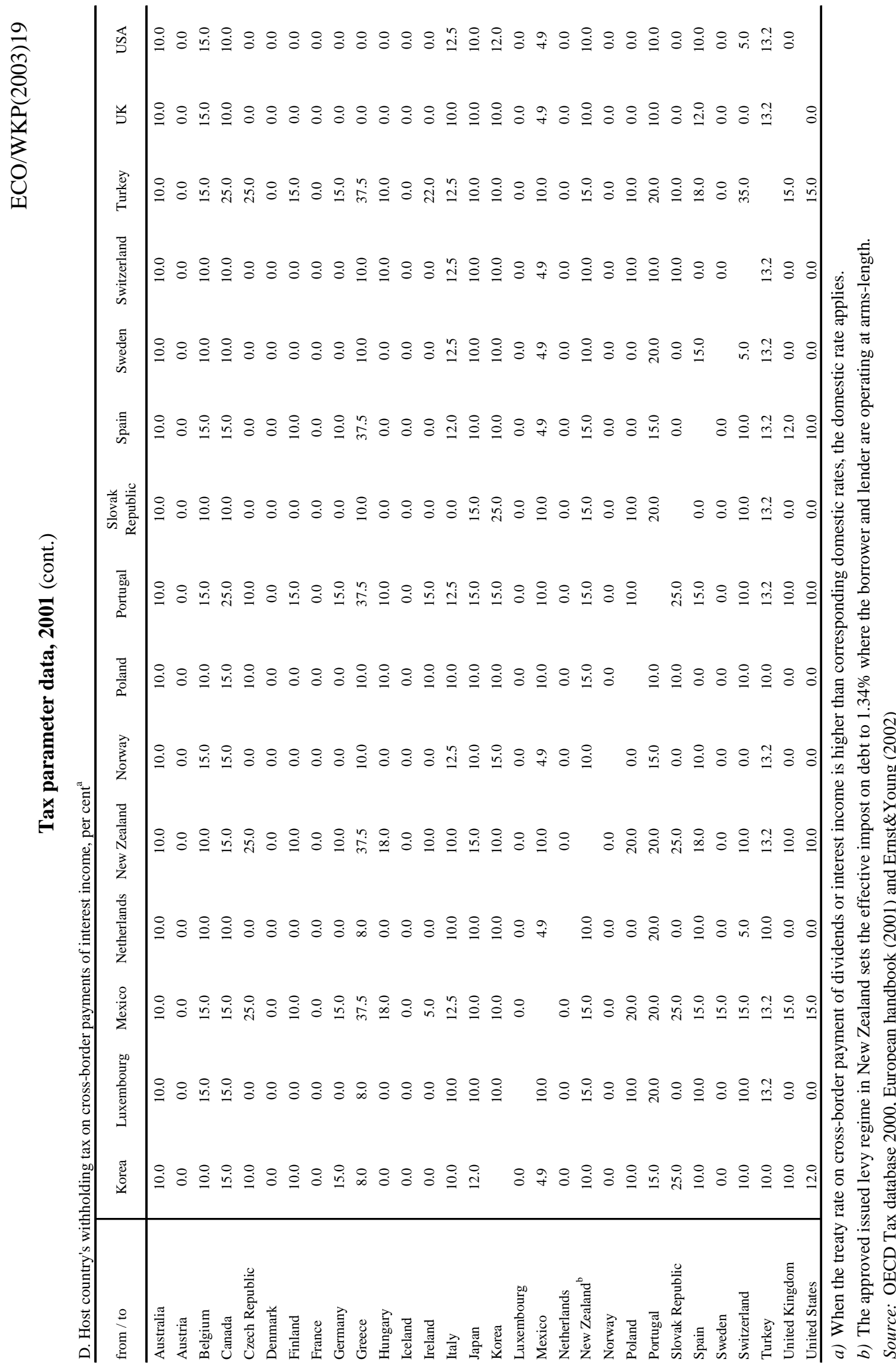




\section{Bibliography}

ALTSHULER, R., H. GRUBERT and T.S. NEWLON (1998),

"Has U.S. investment abroad become more sensitive to tax rates?", NBER Working Paper No. 6368.

ALTSHULER, R., and H. GRUBERT (2002),

"Repatriation taxes, repatriation strategies and multinational financial policy", Journal of Public Economics Vol. 87.

CAREY, D. and H. TCHILINGUIRIAN (2000),

"Average effective tax rates on capital, labour and consumption", OECD Economics Department working paper No.258.

CLAUSING, K.A. (1998),

"The impact of transfer pricing on intrafirm trade", NBER Working Paper No. 6688.

COLLINS, J.H. and D.A. SHACKELFORD (1995),

Corporate domicile and average effective tax rates: the cases of Canada, Japan, the UK and USA, International Tax and Public Finance, Vol. 2.

DESAI, M.A., F. FOLEY and J.R HINES (2002),

"Chains of ownership, regional tax competition and foreign direct investment", NBER Working

Paper No. 9224.

DEVEUREUX, M.P. and R. GRIFFITH (1998),

"Taxes and the location of production: evidence from a panel of US multinationals", Journal of Public Economics 68.

DEVEUREUX, M.P. and R. GRIFFITH (1999),

"The taxation of discrete investment choices", Institute for Fiscal Studies Working Paper No.W98/16.

ERNST AND YOUNG (2002),

Worldwide Corporate Tax Guide.

EUROPEAN COMMISSION (2001),

Company taxation in the internal market, European Commission Staff Working Paper

$\operatorname{COM}(2001) 582$.

GRESIK, T.A. (2001),

"The taxing task of taxing transnationals", Journal of Economic Literature Vol. 39, September.

GRUBERT, H. (1998),

"Taxes and the division of foreign operating income among royalties, interests, dividends and retained earnings", Journal of Public Economics 68.

GRUBERT, H. (2001),

"Enacting dividend exemption and tax revenue", National Tax Journal Vol. 54/4. 
GRUBERT, H. and J. MUTTI (1991),

"Taxes, tariffs and transfer pricing in multinational corporate decision making", Review of Economics and Statistics 73/2.

HARRIS, D.G (1993),

“The impact of US tax law revision on multinational corporations' capital location and income shifting decisions", Journal of Accounting Research 31.

HINES, J.R and G. HUBBARD (1990),

"Coming home to America: dividend repatriations by US multinationals", in Taxation in the Global Economy, edited by A. Razin and J. Slemrod, Chicago: University Press.

HINES, J.R. and E.M. RICE (1994),

"Fiscal paradise: foreign tax heavens and American business", Quarterly Journal of Economics $109 / 1$.

INTERNATIONAL BUREAU OF FISCAL DOCUMENTATION (various years), European Tax Handbook, Amsterdam.

KING, M.A. and D. FULLERTON (1984),

The Taxation of Income From Capital: A Comparative Study of the United States, the United Kingdom, Sweden and West Germany, University of Chicago Press.

KPMG (1998),

Taxfacts.

MENDOZA, E.G., A. RAZIN and L.L. TESAR (1994),

Effective tax rates in macroeconomics: cross-country estimates of tax rates on factor incomes and consumption, NBER working paper No. 4864.

OECD (1991),

Taxing Profits in a Global Economy, Paris.

OECD (1995),

Transfer Pricing Guidelines for Multinational Enterprises and Tax administrations, Paris.

OECD (various years),

OECD Tax Databases.

PAPKE, L.E (1991),

"Interstate business tax differentials and new firm location: evidence from panel data", Journal of Public Economics 45.

PRICE WATERHOUSE (1997),

Corporate Taxes: A Worldwide Summary.

ROUSSLANG, D.J. (1997),

"International income shifting by US multinational corporations", Applied Econometrics 29.

SLEMROD, J.(1990),

"Tax effects on foreign direct investment in the United States: Evidence from a cross-country 
ECO/WKP(2003)19

comparison", In Taxation in the Global Economy, edited by A. Razin and J. Slemrod, Chicago, University of Chicago Press.

SWENSON, D.L. (1994),

"The impact of U.S. tax reform on foreign direct investment in the United States", Journal of Public Economics 54/2.

WEICHENRIEDER, A. (1996),

"Fighting international tax avoidance: the case of Germany", Fiscal Studies 17.

WILSON, J.D. (1991),

"Tax competition with interregional differences in factor endowments", Regional Science and Urban Economics 21. 


\section{WORKING PAPERS}

The full series of Economics Department Working Papers can be consulted at www.oecd.org/eco/Working_Papers/

364. Indicator Models of Real GDP Growth in Selected OECD Countries

(July 2003) Franck Sédillot and Nigel Pain

363. Post-Crisis Change in Banking and Corporate Landscapes - the Case of Thailand (July 2003) Margit Molnar

362. Post-Crisis Changes in Banking and Corporate Landscapes in Dynamic Asia (June 2003) Margit Molnar

361. After The Telecommunications Bubble (June 2003) by Patrick Lenain and Sam Paltridge

360. Controlling Public Spending in Iceland (June 2003) Hannes Suppanz

359. Policies and International Integration: Influences on Trade and Foreign Direct Investment (June 2003) Giuseppe Nicoletti, Steve Golub, Dana Hajkova, Daniel Mirza, Kwang-Yeol Yoo

358. Enhancing the Effectiveness of Public Spending in Finland (June 2003) Philip Hemmings, David Turner and Seija Parviainen

357. Measures of Restrictions on Inward Foreign Direct Investment for OECD Countries (May 2003) Stephen S. Golub

356. Tax Incentives and House Price Volatility in the Euro Area: Theory and Evidence (May 2003) Paul van den Noord

355. Structural Policies and Growth: A Non-technical Overview (May 2003) Alain de Serres

354. Tax Reform in Belgium (May 2003) David Carey

353. Macroeconomic Policy and Economic Performance (April 2003) Pedro de Lima, Alain de Serres and Mike Kennedy

352. Regulation and Investment (March 2003) Alberto Alesina, Silvia Ardagna, Giuseppe Nicoletti and Fabio Schiantarelli

351. Discretionary Fiscal Policy and Elections: The Experience of the Early Years of EMU (March 2003) Marco Buti and Paul van den Noord

350. The US Health System: An Assessment and Prospective Directions for Reform (February 2003) Elizabeth Docteur, Hannes Suppanz and Jaejoon Woo

349. The Effectiveness of Public Expenditure in Portugal (February 2003) Chiara Bronchi

348. Comparative Analysis of Firm Demographics and Survival: Micro-Level Evidence for the OECD Countries (February 2003) Eric Bartelsman, Stefano Scarpetta and Fabiano Schivardi

347. Regulation, Productivity and Growth: OECD Evidence (January 2003) Giuseppe Nicoletti and Stefano Scarpetta 


\section{ECO/WKP(2003)19}

346. Public Expenditure Management in Poland

(December 2002) Andrew Burns and Kwang-Yeol Yoo

345. Enchancing the Effectivesness of Public Expenditure in Sweden

(December 2002) Deborah Roseveare

344. The Decline in Private Saving Rates in the 1990s in OECD Countries: How Much Can Be Explained by NonWealth Determinants

(November 2002) Alain de Serres and Florian Pelgrin

343. Enhancing the Effectiveness of Public Expenditure in Norway

(October 2002) Isabelle Joumard and Wim Suyker

342. Productivity and Convergence in a Panel of OECD Countries: Do Regulations and Institutions Matter? (September 2002) Stefano Scarpetta and Thierry Tressel

341. Managing Public Expenditure: The UK Approach (August 2002) Paul van den Noord

340. The Brazilian Pension System: Recent Reforms and Challenges Ahead (August 2002) Marcos Bonturi

339. Challenges in the Mexican Financial Sector (August 2002) Marcos Bonturi

338. Coping with Population Ageing in Hungary (August 2002) Andrew Burns and Jaromir Cekota

337. Next Steps for Public Spending in New Zealand: The Pursuit of Effectiveness (July 2002) Dave Rae

336. Strengthening the Management of Public Spending in Hungary (July 2002) Jaromir Cekota, Rauf Gonenc and Kwang-Yeol Yoo

335. Automatic Stabilisers and Market Flexibility in EMU: Is There a Trade-Off? (July 2002) Marco Buti, Carlos Martinez-Mongay, Khalid Sekkat and Paul van den Noord

334. The Economic Consequences of Terrorism (July 2002) Patrick Lenain, Marcos Bonturi and Vincent Koen

333. Investment in human capital through post-compulsory education and training: Selected efficiency and equity aspects (July 2002) Sveinbjörn Blöndal, Simon Field and Nathalie Girouard

332. Enhancing the Effectiveness of Public Spending in Switzerland (June 2002) Isabelle Joumard and Claude Giorno

331. Competition and Efficiency in Publicly Funded Services (June 2002) Jens Lundsgaard

330. Policy Pre-Commitment and Institutional Design: A Synthetic Indicator Applied to Currency Boards (May 2002) Marie-Thérèse Camilleri Gilson

329. The Role of Policy and Institutions for Productivity and Firm Dynamics: Evidence from Micro and Industry Data (April 2002) Stefano Scarpetta, Philip Hemmings, Thierry Tressel and Jaejoon Woo 